\title{
Botswana: Selected Issues and Statistical Appendix
}

This Selected Issues paper and Statistical Appendix for Botswana was prepared by a staff team of the International Monetary Fund as background documentation for the periodic consultation with the member country. It is based on the information available at the time it was completed on October 6, 2006. The views expressed in this document are those of the staff team and do not necessarily reflect the views of the government of Botswana or the Executive Board of the IMF.

The policy of publication of staff reports and other documents by the IMF allows for the deletion of market-sensitive information.

To assist the IMF in evaluating the publication policy, reader comments are invited and may be sent by e-mail to publicationpolicy@imf.org.

Copies of this report are available to the public from

International Monetary Fund $\bullet$ Publication Services

700 19th Street, N.W. • Washington, D.C. 20431

Telephone: (202) 6237430 • Telefax: (202) 6237201

E-mail: publications@imf.org • Internet: http://www.imf.org

Price: $\$ 18.00$ a copy

\section{International Monetary Fund Washington, D.C.}





\title{
INTERNATIONAL MONETARY FUND
}

\author{
BOTSWANA
}

\section{Selected Issues and Statistical Appendix}

Prepared by T. Dorsey (head-PDR), O. Basdevant, J. Yeon Kim and A. Iimi (all AFR)

Approved by the African Department

October 6, 2006

Contents

I. Are Diamonds Forever? Using a Lifecycle Approach to Analyze Botswana's Reliance on Diamond Revenues

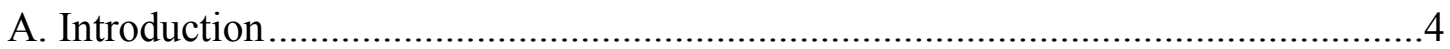

B. The Diamond Sector in Botswana.........................................................................

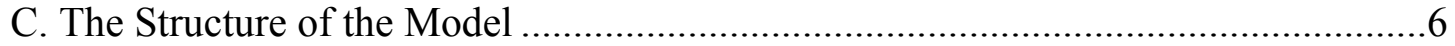

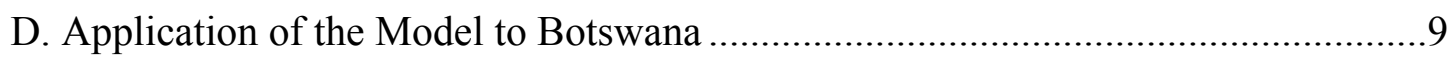

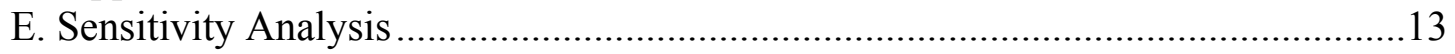

F. Lessons from the Simulation Exercises and Sensitivity Analysis...........................17

II. A Narrow Economy and High Unemployment, Twin Problems for Botswana ...................20

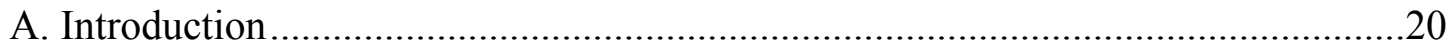

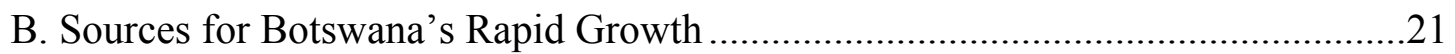

C. Slow Diversification and High Unemployment ...................................................22

Progress on Economic Diversification ………………..............................22

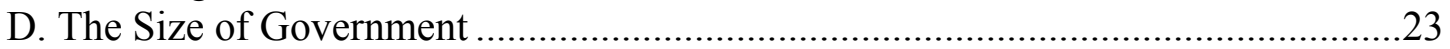

E. Labor Market Conditions and Rising Social Problems ............................................24

F. Factors Underlying the Narrow Economic Base and High Unemployment............25

Employment and Wages in the Public Sector.................................................25

Industrialization in nonmining sector ........................................................2

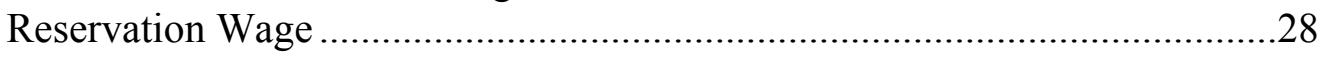

Production Costs, Productivity, and FDI ………………...............................30

G. Conclusion and Policy Implications ………………….........................................

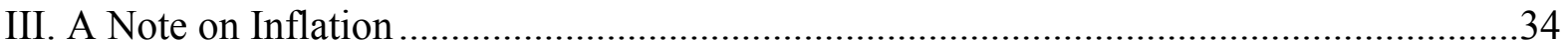

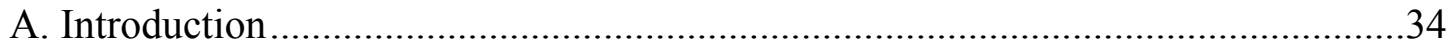

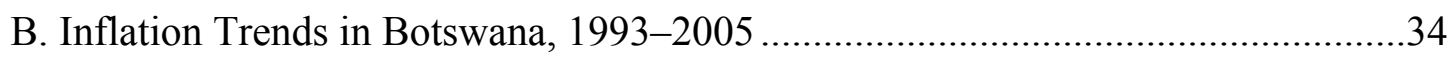

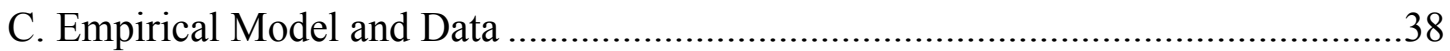

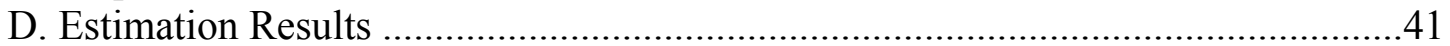

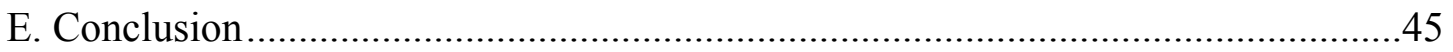


Figures

I.1. Mining and Nonmining Sector Contribution to GDP Growth, 1994/95-2004/05 .......... 5

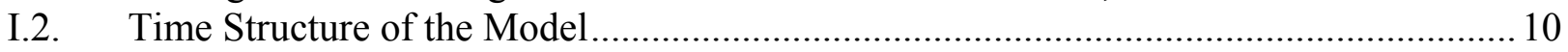

I.3. Projected Diamond Production and Nominal Prices

I.4. Diamond Revenues (million dollars) 2005-29 .................................................. 10

I.5. Permanent and Quasipermanent Income Approaches, 2005-2100 ............................ 12

I.6. Two Alternative Quasipermanent Income Approaches, 2005-49 .............................. 13

I.7. Real Government Expenditures per Capita Index (100=2005), 2005-49 ................... 15

I.8. Impact of a Recession Induced by the End of Diamond Production, 2005-49 ............. 16

I.9. Preparing for Recession by Saving More, 2005-49 .............................................. 17

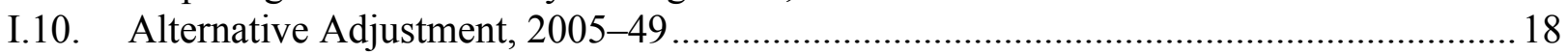

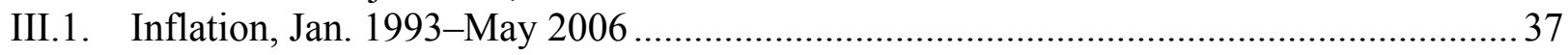

III.2. Inflation and Monetary Growth, Jan. 1993-May 2006 .......................................... 38

III.3. Inflation and Exchange Rate Against the Rand: Jan. 1993-May 2006 ......................... 39

III.4. Inflation and Exchange Rate Against the US\$ and Euro Jan. 1993-May 2006 ............. 40

III.5. Inflation and Exchange Rate Against the SDR Jan. 1993-May 2006 ...........................40

III.6. Impulse Response Function, Unrestriced Model .................................................. 50

III.7. Impulse Response Function, Restricted Model ...........................................................52

Text Tables

I.1. Share of Diamond and Mining Industries in GDP 1995-2005 _..............................5

I.2. Changes in Diamons Prices and Production .......................................................... 14

II.1. Selected Social Indicators ............................................................................... 22

II.2. World Diamond Production Estimates (US\$ billion) ............................................ 23

II.3. Average Monthly Cash Earnings of Botswana Citizens by Sector, 1998-2004 _........... 28

II.4. Public Sector in the Labor Market.........................................................................2 29

II.5. Social Welfare Schemes in Botswana................................................................. 31

II.6. Indices of International Competitiveness ......................................................... 32

II.7. Average Annual Growth Rates of Multifactor Productivity by Sector ........................ 33

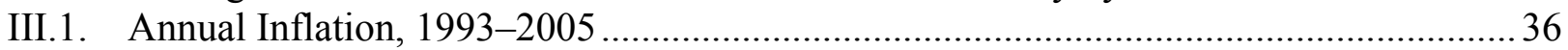

III.2. Correlation Between Inflation and Exchange Rate Depreciation.................................. 39

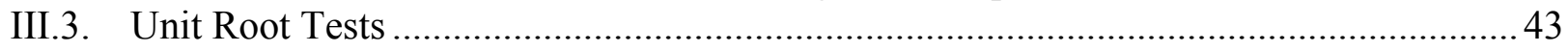

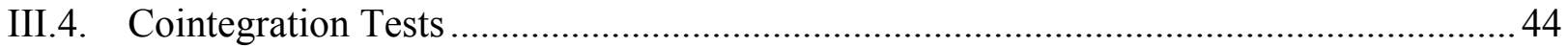

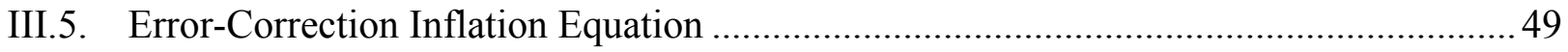

III.6. Granger Causality ....................................................................................... 49

III.7. Alternative Cointegrating Equations for Different CPIs .......................................... 55

III.8. Alternative Cointegrating Equations with Different Independent Variables .................56 
Statistical Appendix tables

1. GDP by Type of Expenditure at Current Prices, 2000/01-2004/05 ............................. 58

2. GDP by Type of Expenditure at Constant 1993/94 Prices, 2000/01-2004/05 ................ 59

3. GDP by Type of Economic Activity at Current Prices, 2000/01-2004/05 .................... 60

4. GDP by Type of Economic Activity at Constant 1993/94 Prices, 2000/01-2004/05 ..... 61

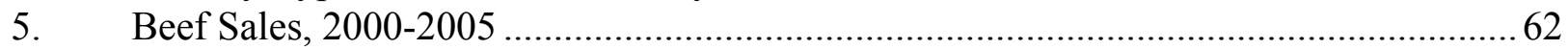

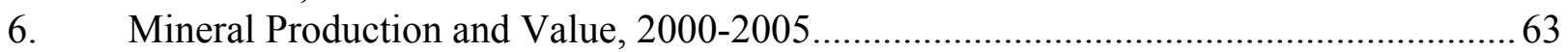

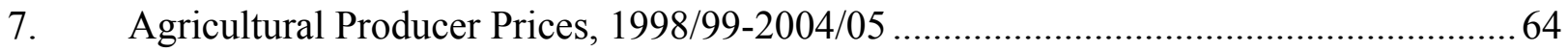

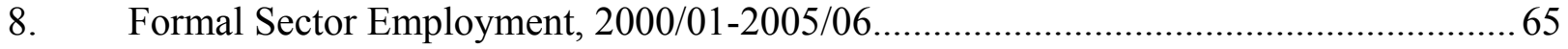

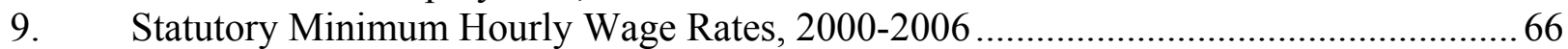

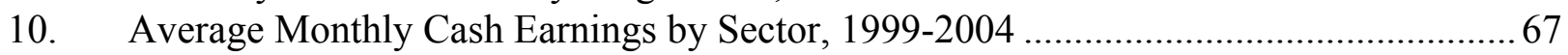

11. Consumer Price Index of Tradables and Nontradables, 1999-2006 ............................ 68

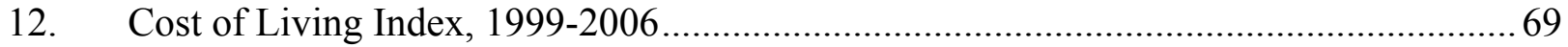

13. Liquid Fuel Import and Retail Prices, 2002-2006 ................................................... 70

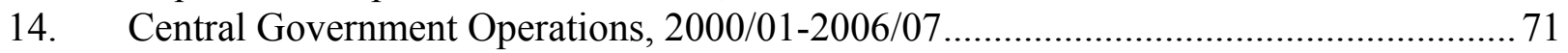

15. Components of Central Government Revenue, 2000/01-2006/07............................... 72

16. Economic Classification of Central Government Expenditure, 2000/01-2006/07 ......... 73

17. Functional Classification of Central Government Expenditure, 2000/01-2006/07 ......... 74

18. Summary of Operations of Nonfinancial Public Enterprises, 2000-2005 ................... 75

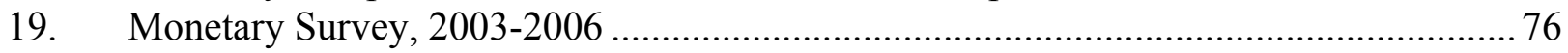

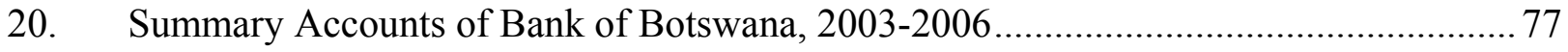

21. Summary Accounts of Commercial Banks, 2003-2006 ......................................... 78

22. Selected Financial Ratios and Aggregates of Commercial Banks, 2001-2006 ............. 79

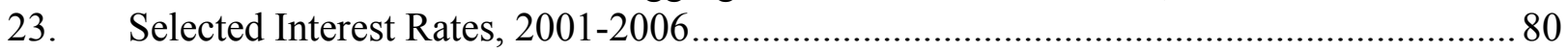

24. Distribution of Commercial Bank Credit by Economic Activity, 2001-2006 _...............81

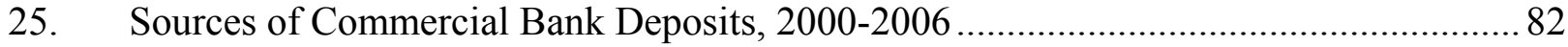

26. Auctions of Bank of Botswana Certificates, 2004-2006 ........................................... 83

27. Value of Outstanding Bank of Botswana Certificates, 2004-2006............................. 84

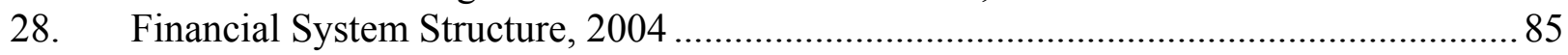

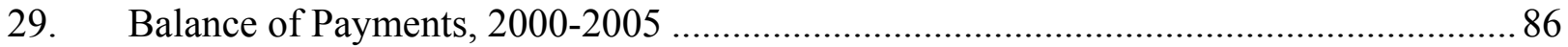

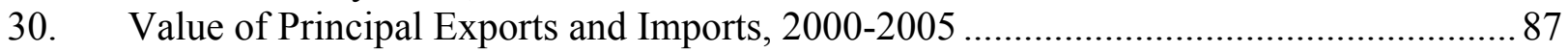

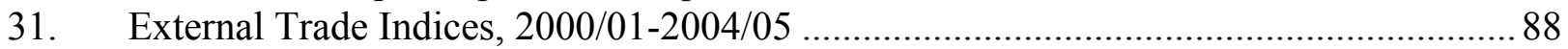

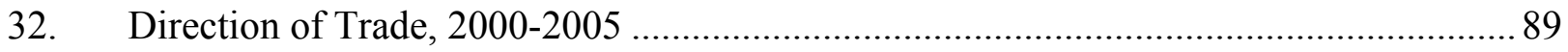

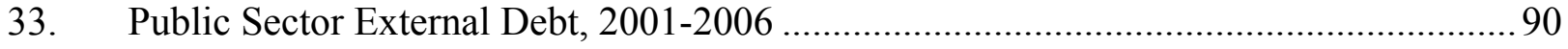

34. External Debt-Service Payments and Disbursements, 2000-2005 .............................. 91

35. Outstanding of Government Bonds, 2004-2006 ..................................................... 92

36. Average Terms of New Public Sector External Borrowing, 1999-2005 ...................... 93

37. Developments in the Exchange Rate, 1990-2006 .................................................. 94

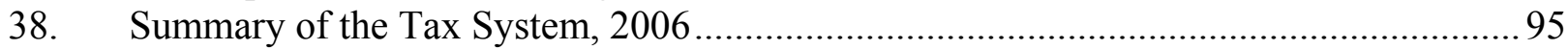




\section{Are Diamonds Forever? Using A Lifecycle ApProach to AnAlyze BOTSWANA'S RELIANCE ON DIAMOND REVENUES ${ }^{1}$}

\section{A. Introduction}

1. Diamond exports, Botswana's main source of foreign exchange, accounted for an average of 75 percent of total annual exports over the past 10 years. Fiscal revenues also depend heavily on diamonds, ${ }^{2}$ which account for 95 percent of minerals revenues. Over the same period, minerals revenues accounted for 63 percent of tax revenues. Botswana is expected to remain the world's leading producer of diamonds well beyond the next decade.

2. This study assesses the fiscal sustainability of Botswana's diamond sector using an analysis designed for oil-exporting countries (see Davoodi 2002, for a general presentation, and Barnett and Ossowski 2003 for an application to oil-producing countries). It applies the permanent income hypothesis (Friedman, 1957) to diamond-related fiscal revenues and the lifecycle approach (Modigliani and Brumberg, 1954) to different expenditure options.

3. This study does not address the optimality of the fiscal policy, since it is not derived from the maximization of an intertemporal utility function. Instead, Botswana's current fiscal rule, which imposes a strict balance between expenditure and revenue, is considered as a given constraint. As a result, government expenditure, over the medium and long term, is constrained by fiscal revenue generated by the economy. Any level of expenditure permanently above fiscal revenue would be unsustainable.

4. Botswana's economy faces a difficult challenge with the depletion of its diamond resources, which are expected to be exhausted around 2030 (Section B). Under the current fiscal rule, and without any additional saving effort, the depletion of diamond resources would imply a sharp fall in government expenditure. A reduction in expenditure of 1 point of GDP per year would generate savings high enough to smooth the adjustment imposed by the depletion of diamond resources. The main specific messages are as follows.

- $\quad$ Strong fiscal adjustment may be necessary to ensure that diamond revenues benefit future generations. Revenue-raising measures would help preserve expenditure, either in level (Section D) or per capita (Section E).

\footnotetext{
${ }^{1}$ Prepared by Olivier Basdevant.

${ }^{2}$ Botswana's diamond production is composed for half of industrial diamonds and half of jewelry diamonds. The latter makes about 80 percent of Diamond revenues.
} 
- $\quad$ The results are sensitive to the uncertainty regarding diamond prices and resources. One additional year of above-ground extraction with a high extraction rate would significantly increase Botswana's capacity to smooth the adjustment (Section E).

- If the economy fails to diversify and create additional sources of growth before the full depletion of diamond resources, then the contraction of fiscal revenue would be far greater, hence putting additional constraint on expenditure (Section E).

5. The rest of this paper is organized as follows. Section B presents an overview of Botswana's diamond sector. Section $\mathrm{C}$ introduces a simple model of permanent income, which is applied in section D to evaluate different policy scenarios (e.g., saving to soften future adjustment), while alternative assumptions (e.g., diamond stock, prices, and GDP growth) are explored in Section E. Section F discusses some issues indirectly related to the analysis.

\section{B. The Diamond Sector in Botswana}

\section{Botswana is one of sub-Saharan Africa's few upper middle-income countries.}

The diamond industry has been a major contributor to Botswana's growth. Over the past 10 years, the mining sector represented an average of 34.5 percent of GDP, with diamonds constituting nearly 94 percent of the sector's total exports (see Table 1). The mining sector was also a main factor contributor to fluctuations in the GDP growth rate over the past decade (see Figure 1).

Table I. 1. Share of Diamond and Mining Industries in GDP 1995-2005

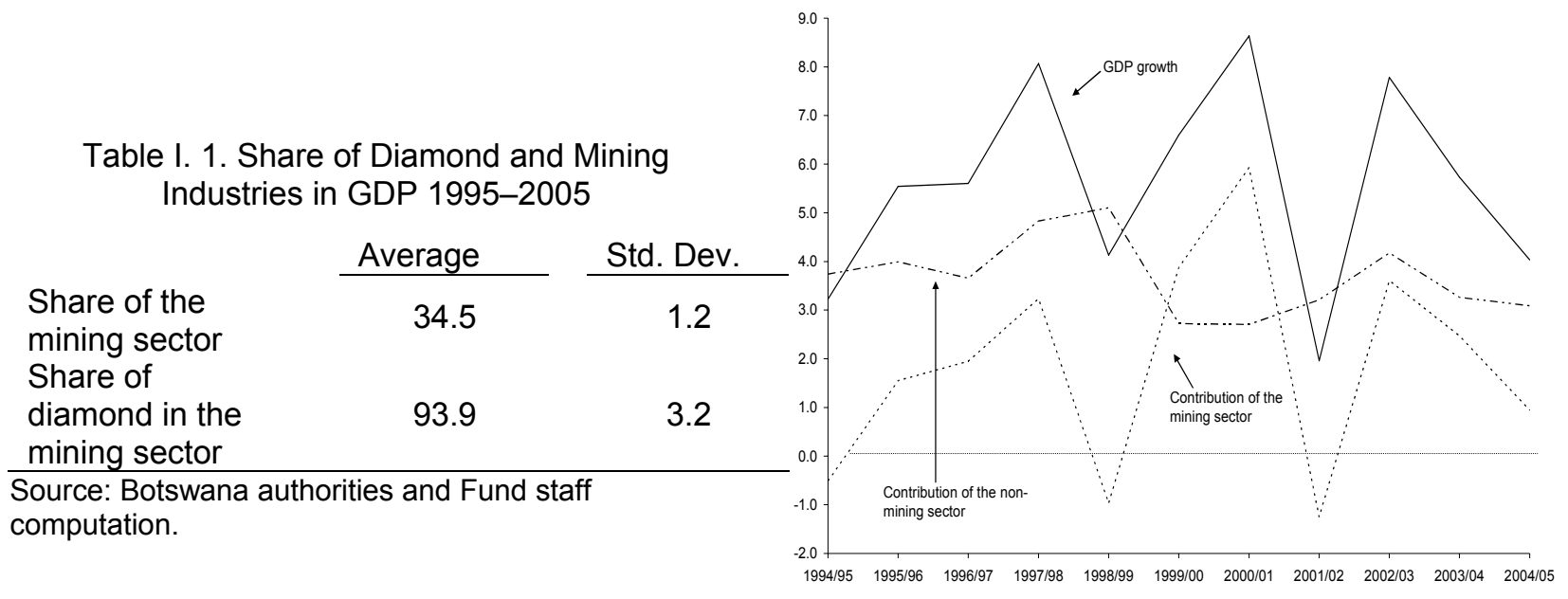

Sources: Botswana authorities and Fund staff computations.

Figure I. 1. Mining and Nonmining Sector Contribution to GDP Growth, 1994/95-2004/05 
7. Over the medium term, Botswana is expected to enjoy sustained growth of around 4 percent a year. Meanwhile, diamond production will continue at high levels until 2021, when a sharp decline will set in until diamond resources are depleted around 2030. The end of diamond production, which now accounts for one-third of GDP and half of government revenues, will severely affect real GDP growth (projected at 3.5 percent in the long run). However, Botswana's efforts to build diamond processing capacity, for domestic as well as foreign mines, could yield additional revenues and help offset diamond production losses.

8. Because of the rapid depletion of diamond resources, fiscal revenues are expected to shrink by about two-thirds from 2021 to 2029. Still, diamond extraction will remain be the main contributor to mineral revenue. Despite expected new mine production (i.e., copper, nickel, and gold), other-mineral profits will likely be relatively modest.

9. When its new plant opens, Debswana, Botswana's joint venture with De Beers, will increase its diamond extraction by 35 percent, though income is expected to grow by a more modest 12-15 percent. Using more modern techniques, the new plant will extract more, though smaller (and thus less profitable), diamonds from Debswana's mine tailings. The plant will also be able to extract more diamonds from the site's large stocks of waste.

10. Nevertheless, production is expected to decrease after 2017, as diamond reserves are drawn down, and then to decrease further as mining goes underground. Sometime between 2015 and 2020, when surface mines are expected to grow fallow, Debswana will need to shift to underground mining, resulting in lower profits (owing to higher extraction costs and decreased output). The profitability and economic feasibility of underground mining are open to question. Though there is some uncertainty about the stock of diamonds, most analysts expect reserves to be depleted by 2029 .

\section{The Structure of the Model}

11. This paper draws on the permanent income hypothesis (PIH) of consumption, an approach widely applied to countries with significant natural resources (oil, gas, and minerals). The steps are as follows: (i) the total diamond resource is estimated; (ii) the net present value (NPV) of this resource is taken to be a financial asset generating a permanent income; and (iii) the income figure is then used to determine how much the government can spend without eroding its long-term fiscal position.

12. The dynamic structure of the approach is based on the intertemporal budget constraint, which can be written in period $t$ as follows:

$$
T_{t}^{D}+T_{t}^{O}+i_{t} A_{t-1}-G_{t}=A_{t}-A_{t-1}
$$

where $T^{D}$ is diamond-related revenue; $T^{O}$ is other (tax and nontax) revenue; $i_{t}$ is the interest on net government financial assets, $A_{t}$; and $G$ is government consumption. 
13. Let $W^{D}$ be the NPV of diamond revenues. At date $t$, it is defined as

$$
\begin{gathered}
i_{t} W_{t-1}^{D}-T_{t}^{D}=W_{t}^{D}-W_{t-1}^{D}, \\
\text { or: } \quad W_{t}^{D}=\sum_{j=t+1}^{T} \frac{T_{t}^{D}}{\prod_{\tau=t+1}^{j}\left(1+i_{\tau}\right)},
\end{gathered}
$$

where $T$ is the period beyond which diamond resources are totally exhausted. Equation 2 accurately defines $W$, which is inherently forward looking and based on both expected interest rates and expected revenues (see Figure 2). The results therefore depend not only on the structure of the model but also on the uncertainty surrounding the measurement of future variables.

Figure I. 2: Time Structure of the Model

\begin{tabular}{l} 
Stocks \\
\multicolumn{3}{|c|}{ Flows } \\
\multicolumn{1}{|c|}{ Period $t$}
\end{tabular}

14. The total financial wealth of the government is used as an annuity, which is translated into a permanent and sustained flow of public expenditure. Let $W^{O}$ be the net financial asset generated by nondiamond revenues:

$$
W_{t}^{O}=\sum_{j=t+1}^{+\infty} \frac{T_{j}^{O}}{\prod_{\tau=t+1}^{j}\left(1+i_{\tau}\right)} .
$$

The budget constraint of the government imposes a balanced budget over the long run. The intertemporal budget constraint can be derived from equation 1:

$$
A_{t}=\sum_{j=t+1}^{+\infty} \frac{\left(T_{j}^{O}+T_{j}^{D}-G_{j}\right)}{\prod_{\tau=t+1}^{j}\left(1+i_{\tau}\right)} .
$$


That is, the net financial asset at period $t$ should be equal to future net savings (NPV of future net revenue minus consumption). Assuming, for simplicity, that $A_{t}=0$, it follows that

$$
\sum_{j=t+1}^{+\infty} \frac{G_{j}}{\prod_{\tau=t+1}^{j}\left(1+i_{\tau}\right)}=W_{t}^{D}+W_{t}^{O}
$$

That is, the NPV of future consumption is equal to the total financial wealth at the government's disposal.

If we now turn to the PIH, assuming that consumption grows at a constant rate $g$ : $\forall \tau \geq t+1$ $G_{\tau}=(1+g)^{\tau-t-1} G_{t+1}$. With a constant interest $i$, the result is:

$$
\begin{aligned}
W_{t}^{D}+W_{t}^{O} & =\sum_{j=t+1}^{+\infty}\left(\frac{1}{1+i}\right)^{j-t} G_{j} \\
& =G_{t+1} \sum_{j=t+1}^{+\infty} \frac{(1+g)^{j-t-1}}{(1+i)^{j-t}} \\
& =\frac{1}{1+g} G_{t+1} \sum_{j=t+1}^{+\infty}\left(\frac{1+g}{1+i}\right)^{j-t} \\
& =\frac{1}{1+g} G_{t+1}\left(\frac{1+g}{i-g}\right) \\
& \Leftrightarrow G_{t+1}=(i-g)\left(W_{t}^{D}+W_{t}^{O}\right)
\end{aligned}
$$

and

$$
\forall \tau \geq t+1 \quad G_{\tau}=(i-g)(1+g)^{\tau-t-1}\left(W_{t}^{O}+W_{t}^{D}\right) .
$$

15. The total wealth generated by diamond revenues can also be used as quasipermanent income to generate income for a certain time horizon, $T$, Let $Y^{D}$ be this revenue flow:

$$
\sum_{j=t+1}^{T^{\prime}}\left(\frac{1}{1+i}\right)^{j-t} Y_{j}^{D}=W_{t}^{D}
$$

Assuming that this flow is used to generate quasipermanent income that grows at a rate of $g$, it follows that:

$$
Y_{t+1}^{D}=(i-g)\left(1-\left(\frac{1+g}{1+i}\right)^{T^{\prime}-t}\right)^{-1} W_{t}^{D}
$$

and

$$
\forall T^{\prime} \geq \tau \geq t+1 \quad Y_{\tau}^{D}=(1+g)^{\tau-t-1}(i-g)\left(1-\left(\frac{1+g}{1+i}\right)^{T^{\prime}-t}\right)^{-1} W_{t}^{D}
$$

Equation 7 would then be rewritten as follows: 


$$
\left\{\begin{array}{l}
\forall T^{\prime} \geq \tau \geq t+1 \quad G_{\tau}=(i-g)(1+g)^{\tau-t-1} T_{t}^{O}+Y_{t}^{D} \\
\forall \tau>T^{\prime} \quad C_{\tau}=(i-g)(1+g)^{\tau-t-1} T_{t}^{O}
\end{array} .\right.
$$

Thus, the quasipermanent income approach consists in concentrating the annuities generated by diamond revenues in a finite period, which induces a higher revenue for this period but necessitates an adjustment beyond it. Section D shows how this approach might be relevant to Botswana, where diamond resources may not provide permanent income high enough to both ensure fiscal sustainability and meet the authorities' development objectives.

\section{Application of the Model to Botswana}

16. Diamond revenue's projections results from projections of diamond production and prices (Figure 3 and 4). The profile for diamond production and prices summarized in Figure I. 3 is a stylized representation of information gathered from Debswana and the Ministry of Minerals and Water Resources. ${ }^{3}$ The price trend is a result of three assumptions: (i) a constant price in real terms of about US\$100 a carat, (ii) a nominal 2 percent inflation rate, and (iii) a discounted average price for 2012-18 to reflect the reprocessing of waste using newer extraction technologies. Production increases gradually, from 32 million carats in 2005 to 44 million carats in 2017, mostly reflecting diamond production from reprocessed mine waste. Them from 2017 production will fall as resources accesible from above-ground resources are depleted, until 2021 where another decline will occur as underground resources are much less rich and more difficult to extract, making mining less productive.

\section{Diamond resources are not adequate to permanently finance a significant share} of government expenditure. Applying the PIH with an infinite time horizon, projected diamond revenues represent only 1 percent of GDP, compared to 19.5 percent for nondiamond revenues. Using the assumptions summarized in Table 2, and assuming, for simplicity, that interest rates are constant, the NPV of diamond revenues in 2005 would be $W^{D}=158$ billion pula. Once converted into a permanent income growing at the same rate of GDP, this sum leads to a long-run annuity of 1 percent of GDP, compared with the 2005 values of 19.8 percent of GDP for nondiamond fiscal revenues and 19.5 percent of GDP for diamond revenues.

\footnotetext{
${ }^{3}$ To protect the confidentiality of information, the actual data were smoothed and stylized, although more precise calculations were discussed with the authorities.
} 
Figure I. 3. Projected Diamond Production and Nominal Prices 2005-29

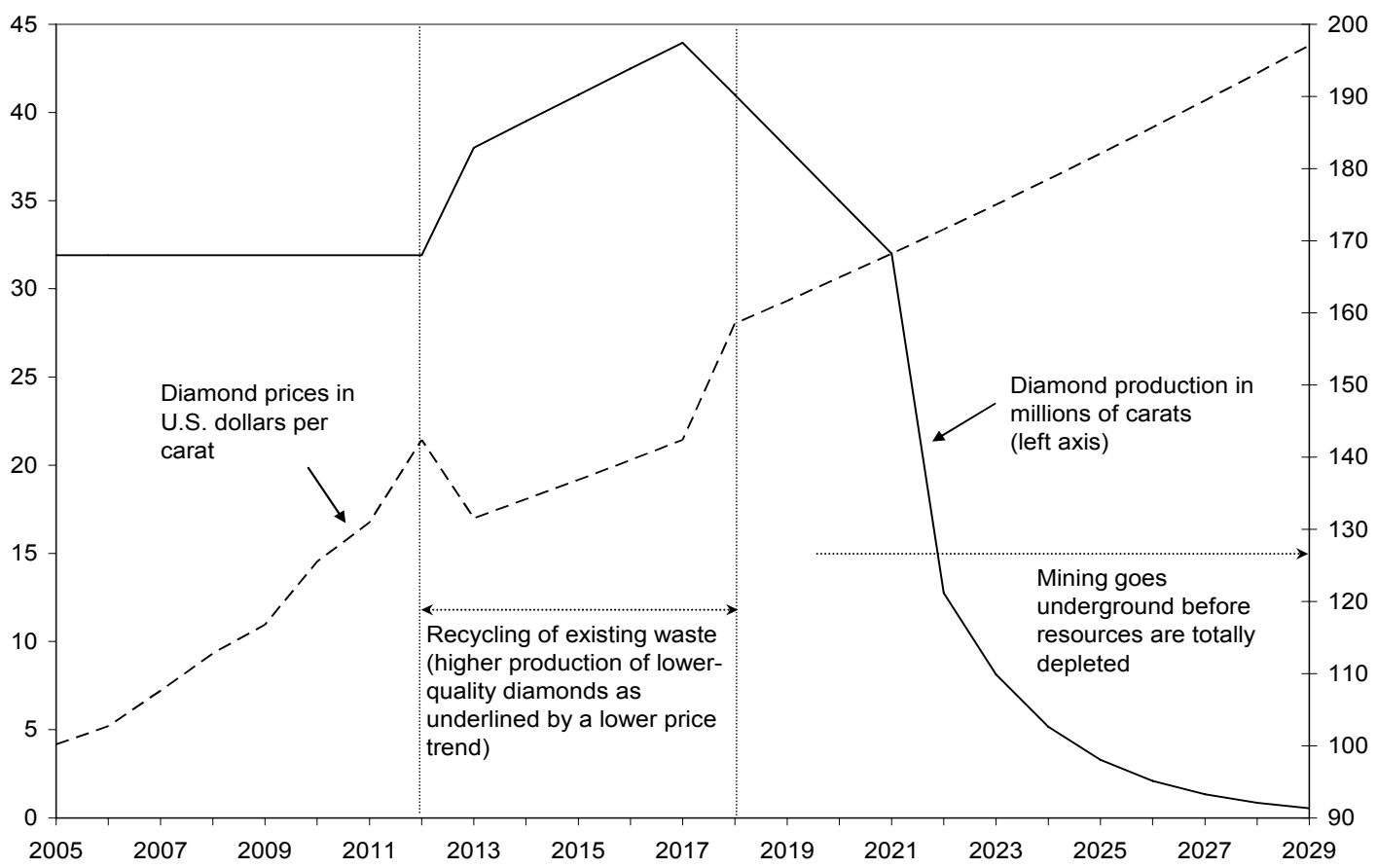

Source: Fund staff computations based on government information.

Figure I. 4. Diamond Revenues (million dollars) 2005-29.

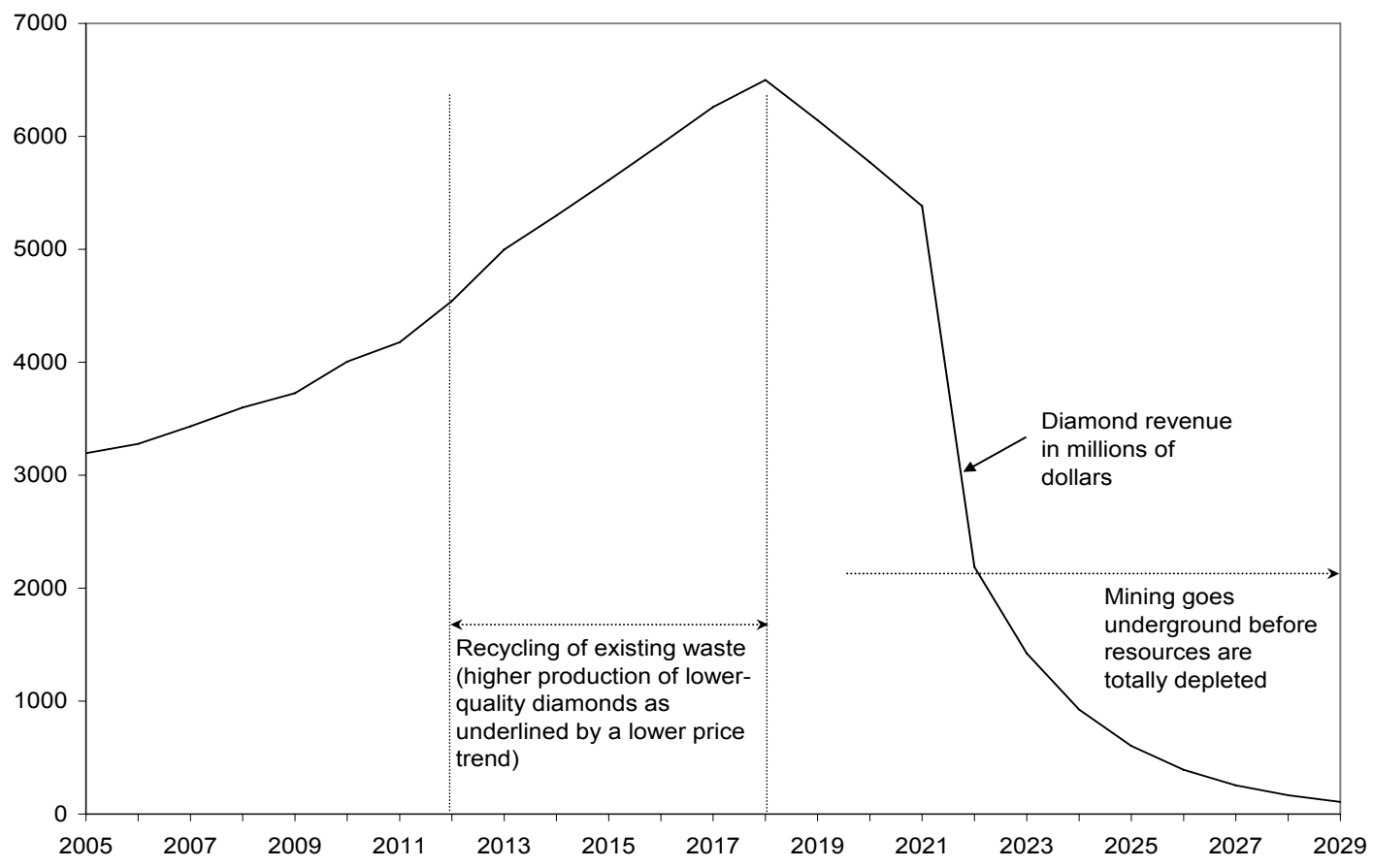

Source: Fund staff computations based on government information. 
18. When applying the model, the main assumptions made for the long term are as follows.

- In the long run, all real variables, notably the GDP grow at the same rate of 4.5 percent a year.

- $\quad$ Purchasing power parity holds in relative terms. World inflation is 2 percent, while domestic inflation is 4.5 percent.

- As of 2005, the population is 1.7 million and grows at a constant rate of 2 percent a year.

19. The authorities might thus consider (i) smoothing the path of diamond revenues over the medium term, (ii) continuing to diversify the economy, and (iii) creating new sources of income to help finance Botswana's development needs. As implied by the PIH exercise, unlike some oil-producing countries, Botswana cannot rely on its diamond resources to finance long-term expenditure. The exercise also suggests that, given the expected short-term horizon of remaining diamond resources, a strategy of revenue saving must be implemented before (or in addition to) other revenue-generating measures.

20. Under a quasipermanent income approach, an alternative to the infinite horizon PIH, diamond resources could generate income of 2.7 percent of GDP in 2021-49, while preserving much higher revenue through 2021 (see Figure 4). The revised assumptions are as follows:

- $\quad$ The time horizon is shortened to 2049, leaving 20 years of annuities once diamond production ends. In addition, along with a gradual partial adjustment in savings, longterm reforms would ensure that public expenditures are fully sustainable.

- Instead of assuming that the current NPV of diamond stocks is directly transformed into a financial annuity growing at a constant rate, the authorities are assumed to gradually increase their saving of diamond revenues. The first years of revenue mostly finance expenditures, though some savings could be used to finance an annuity until a certain date (2049 is proposed here), after which further adjustment would be needed.

- $\quad$ More gradual adjustment in savings would limit the impact on development and poverty-related expenditures. The pure PIH approach, by contrast, implies a sharp drop in revenues in the first few years.

\footnotetext{
${ }^{4}$ The time horizon in the quasipermanent income approach is fixed arbitrarily to 2049 , i.e. a time-horizon rather long. The main point here is to propose an adjustment in two steps, where 2049 represents this second step, i.e. the end of the diamond-related annuity, which is far enough in the future to prepare an adjustment over a time horizon longer than the one of diamond depletion.
} 
- The quasipermanent income approach implies a three-phase adjustment: (i) during the diamond extraction period, savings are increased gradually, though by much less than in the PIH; (ii) during a protracted period (between 2021 and 2049 here), these savings generate a higher annuity (2.7 percent of GDP) than in the PIH ( 1 percent of GDP), owing to the finite time horizon; and (iii) beyond 2050, additional adjustment would be needed, including structural and other measures to support growth and create more public spending resources.

Figure I. 5. Permanent and Quasipermanent Income Approaches, 2005-2100

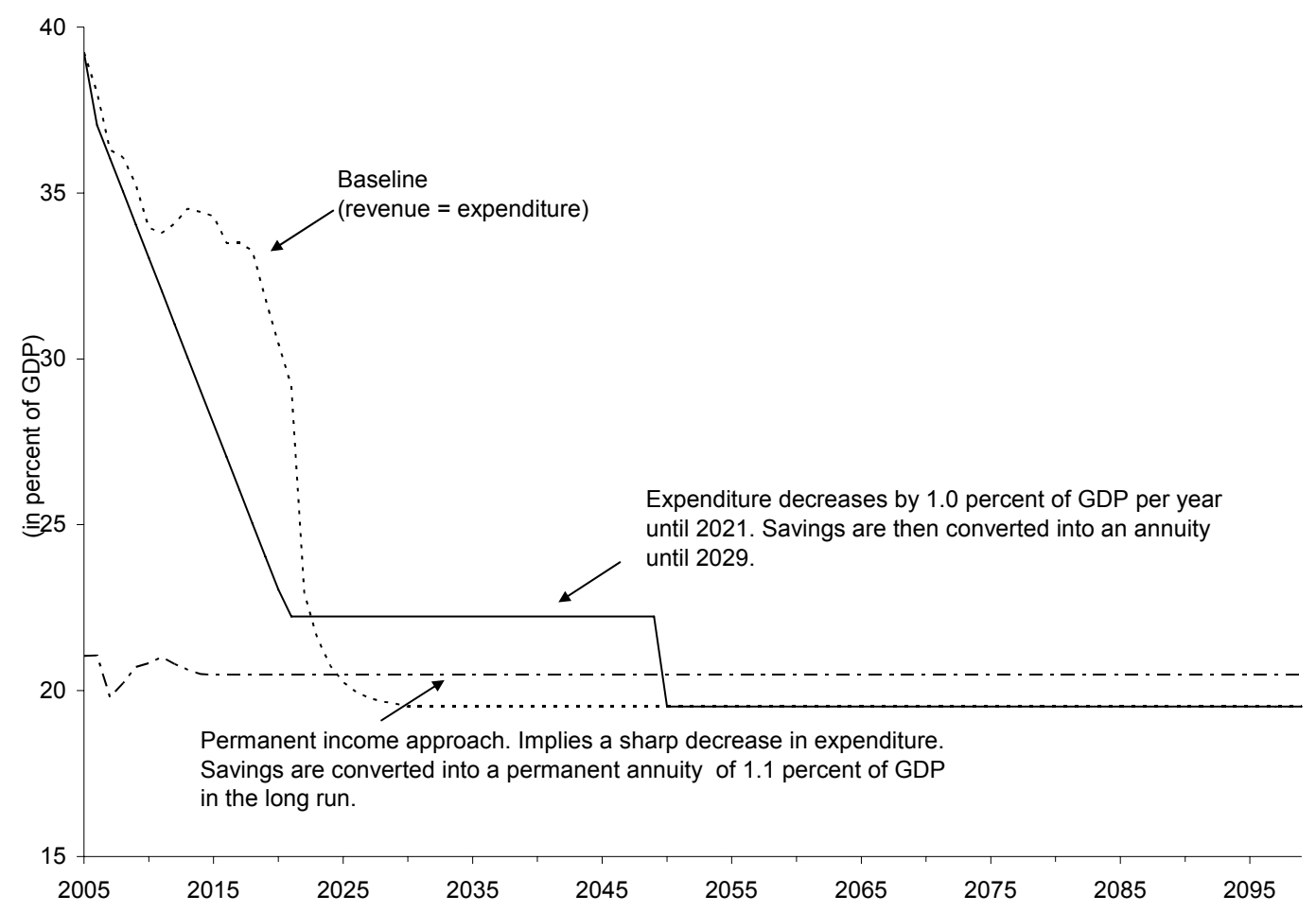

Source: Botswana authorities and Fund staff computations.

\section{The adjustment needed for a soft landing requires a sharp reduction in spending}

as a share of GDP. Of the adjustment options open to the authorities, the ideal would:

(i) avoid cutting expenditure too steeply in the short term, which could be disruptive; and

(ii) cut enough to ensure a soft landing. The simple approach adopted here evaluates two policies - reducing expenditure by 1.0 percent of GDP a year and by 0.5 percent a year. As shown in Figure I. 6, an adjustment of 0.5 percent per year, a considerable amount, would allow the economy to sustain high government expenditure over a longer period, though deficits would accumulate even before diamond resources were exhausted, creating the need for greater adjustment later on. Thus, in the absence of offsetting revenues from economic diversification, only an adjustment of 1 percent a year or more would likely ease the impact of diamond depletion. 
Figure I. 6. Two Alternative Quasipermanent Income Approaches, 2005-49

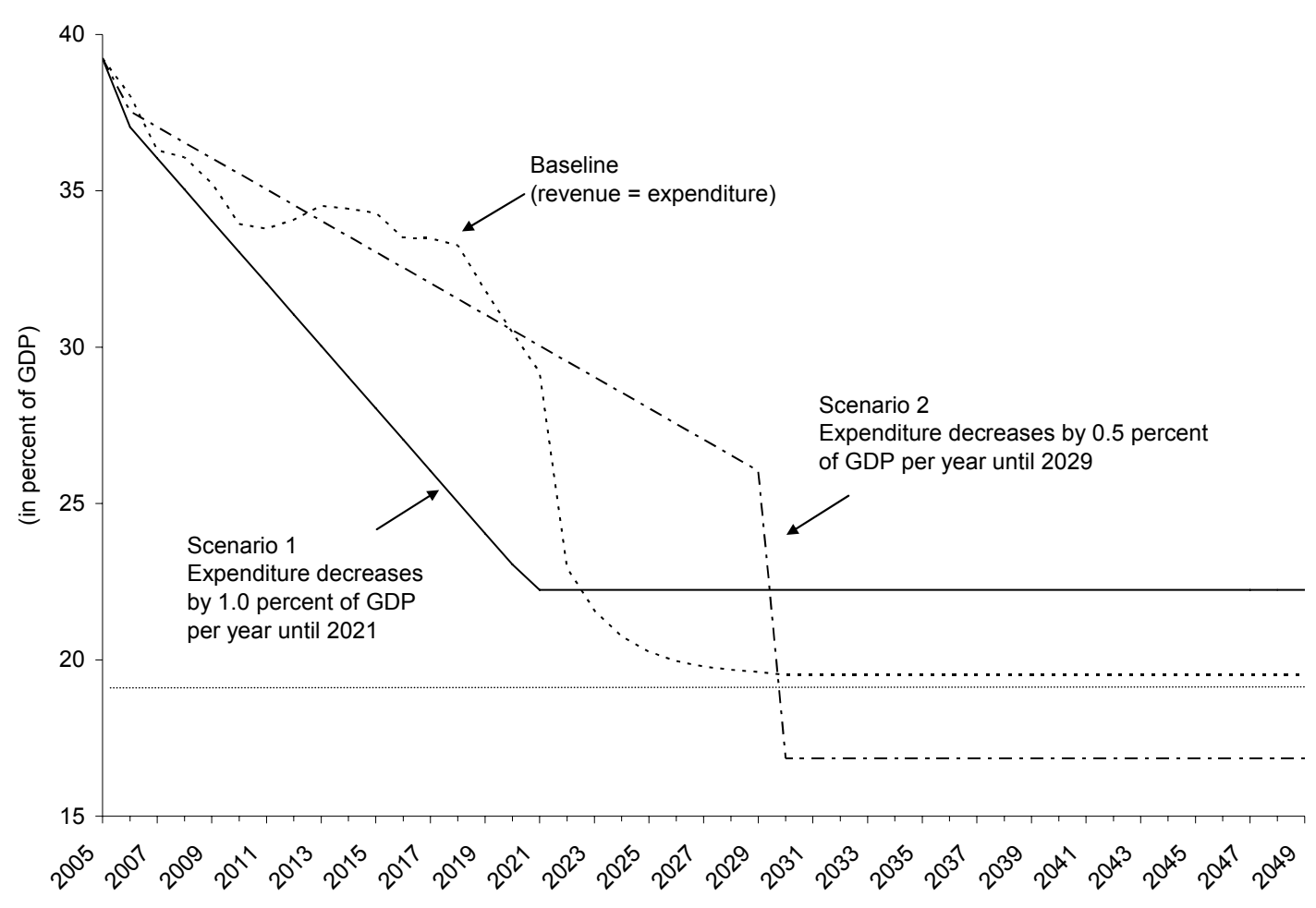

Source: Botswana authorities and Fund staff computations.

\section{E. Sensitivity Analysis}

22. Because Botswana is a price maker in the diamond market, lower production is likely to lead to higher prices, hence offering a partial compensation for a lower production. Because a sharp drop in Botswana's production would imply a major structural change in the diamond market, and because of a lack of data, it is almost impossible to quantify Botswana's market power. However, being in a situation of a quasi-monopoly it would definitely be possible to exploit this situation and to extend the production period, hence increasing the profit per carat, in order to maximize the net present value of diamondrelated fiscal revenues. Bostswana's market power might also vanish as production decline, because the production of other countries could increase and impose greater competition.

23. Because we cannot precisely quantify Botswana's market power, we present a partial analysis showing, everything being equal, where a 1 percent price increase, during the period of diamond depletion, induces a increase of 0.1 percent of the NPV of diamond revenues (see Table 3). The impact on the long-term value of the annuity is rather modest, with an increase of 0.01 percentage point of the GDP. While the absolute impact, particularly on the annuity, is small, the precise relationship between world diamond prices and Botswana's production needs further investigation.

24. With one more year of high-return above-ground extraction (production of about 32 million carats), the NPV of diamond revenues would increase by 3.8 percent 
and the long-term annuity by 1.1 percent of GDP (see Table 3). As noted earlier, the exact magnitude of diamond resources has not been fully assessed yet. Although both Debswana and the Ministry of Mineral and Water Resources expect production to end around 2029, above-ground extraction could last another year or more. An additional year of above-ground extraction would put production at a much higher level, say, the same as in 2021 (32 million carats), compared with 12.8 million carats in the baseline scenario. In addition, the indirect impact of the authorities' saving effort (owing to the cap on government expenditure) would boost revenue. Indeed, in 2022 the saving rate of diamond revenue would be 24.9 percent, compared with 2.5 percent in the baseline scenario.

Table I. 2. Changes in Diamond Prices and Production

Increase in diamond prices
$(+1$ percent a year 2022-29)

\section{Reducing government expenditure by 1 percent of GDP a year would also imply} reducing real government expenditure per capita, which might have a major impact on the economy. Balancing expenditures and revenues is a necessary condition for fiscal sustainability and Botswana's fiscal law imposes a strictly balanced budget with no debt accumulation. If revenues as a percentage of GDP, are falling, the increased savings will carry a social cost - a net reduction in expenditure per capita - unless GDP growth increases sharply. Figure I. 7 shows the patterns implied by (i) the baseline scenario, which features no adjustment before diamond production declines, and (ii) the scenario assuming a gradual decline in public expenditure of 1 percent of GDP a year. Not surprisingly, the decreased public expenditure leads to a sharper decrease in expenditure per capita. However, greater savings leads government expenditure per capita to recover more quickly during the postdiamond period. The minimum expenditure per capita is also higher in this scenario. 
Figure I. 7. Real Government Expenditures per Capita Index (100=2005), 2005-49

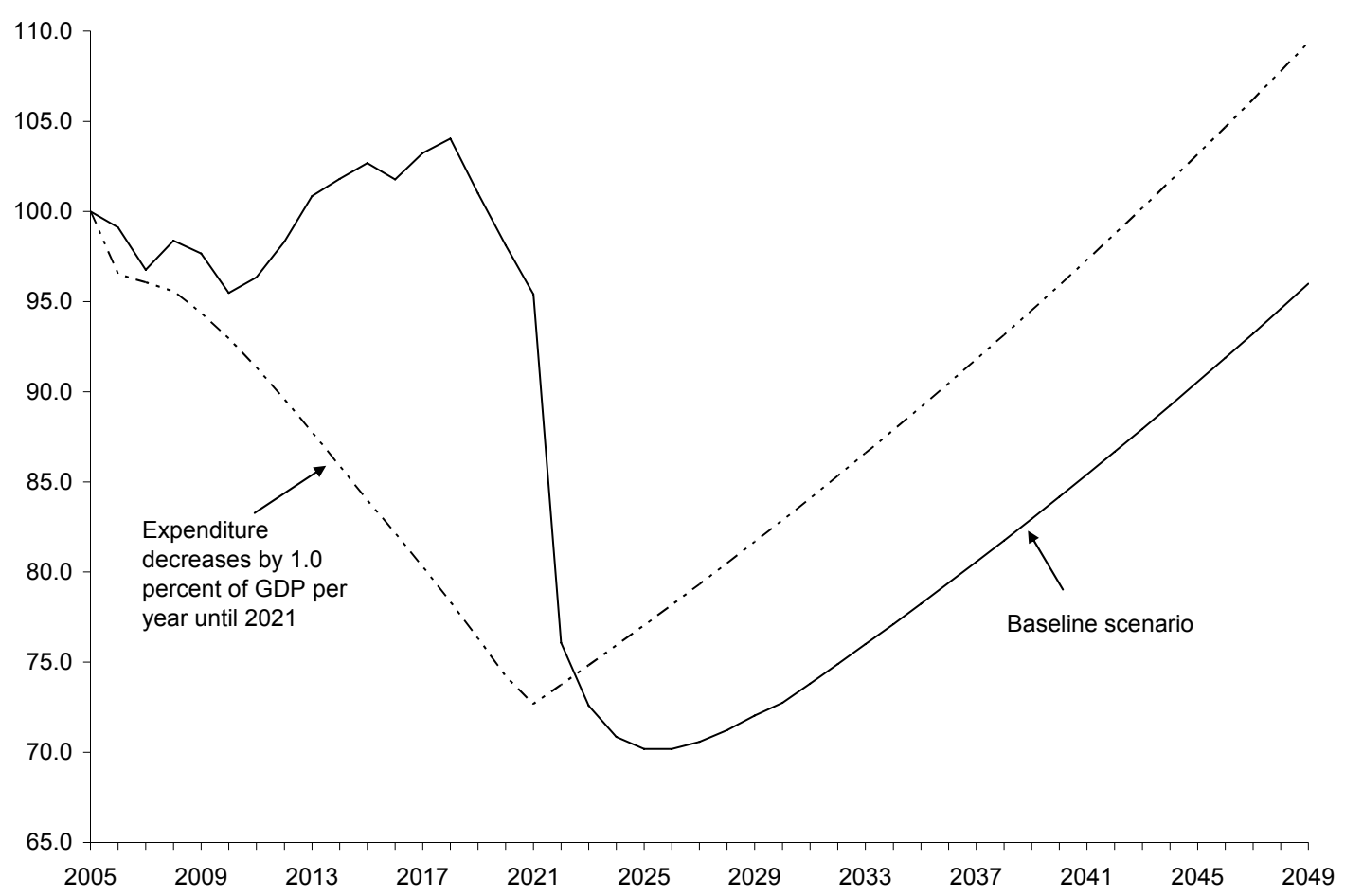

26. Unless the economy is diversified, projected GDP growth is projected to fall sharply after 2021 (by $\mathbf{- 2 4 . 2}$ percent in $\mathbf{2 0 2 2}$, followed by several years of stagnation).

All the scenarios proposed so far assume for total GDP a constant long-term growth of 3.5 percent a year, even with the sharp decline in diamond production. Thus, the baseline projection assumes that greater diversification of the economy would lead to a strong nondiamond-realted GDP growth, which fully compensates for the diamond-related GDP loss, while the alternative scenario assumes that the GDP loss would not be offset in any way. Potential growth, however, is likely to be somewhere in between, since diversification would likely only partly compensate for the GDP loss. For instance, diversification could come partly from diamond processing, since Botswana has invested in this activity, but it would suffer as well from the depletion of diamond resources hence partly compensating for the loss. Figure I. 8, which summarizes both scenarios, shows that the GDP contraction would almost double the cost of the end of diamond production, assuming expenditure per capita in 2021 holds throughout the period. Thus, in this scenario, annual government expenditure per capita would be only 48.7 percent of its 2005 level during the 2022-32 period, before gradually recovering. 
Figure I. 8. Impact of a Recession Induced by the End of Diamond Production, 2005-49

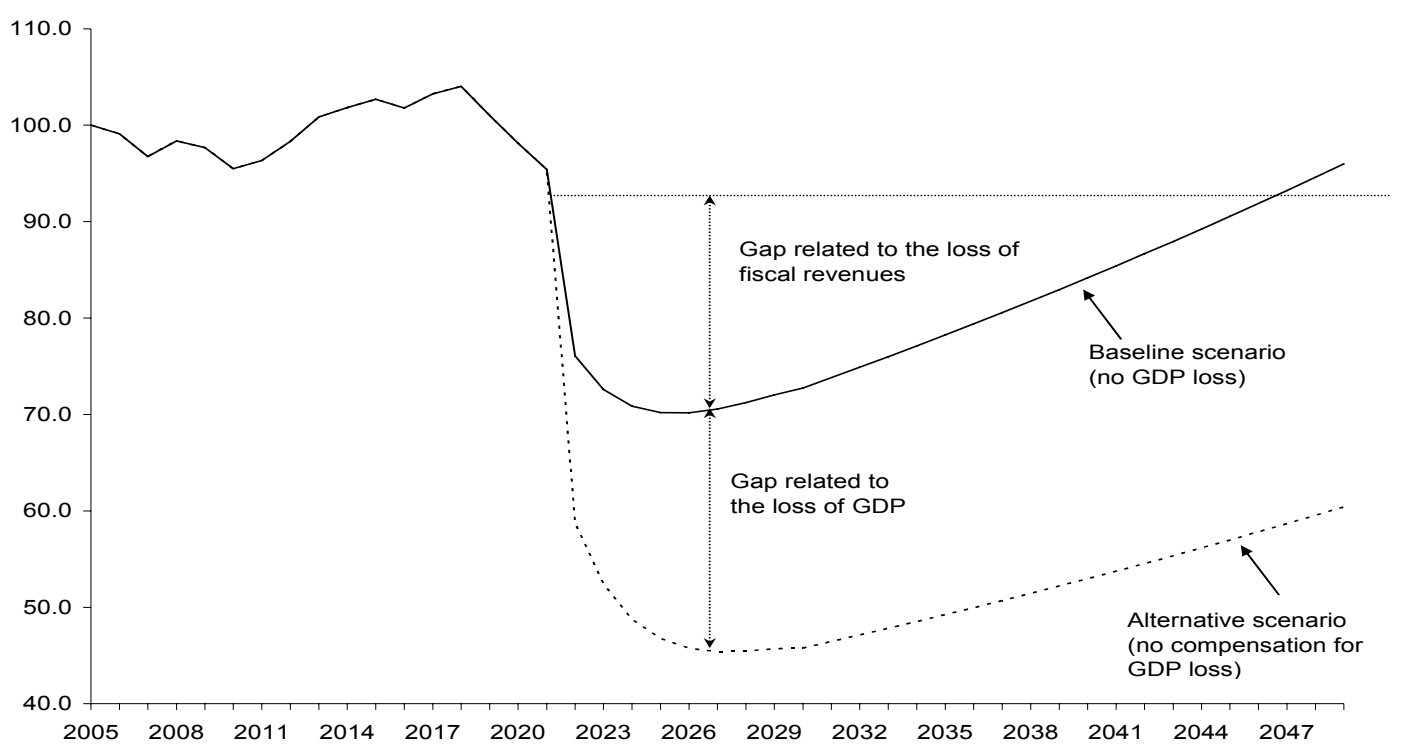

27. With a gradual adjustment in expenditure, the authorities could save additional resources, which would considerably lower the long-term cost of the GDP loss. Additional savings, even without economic diversification, would generate enough quasipermanent income to compensate for the GDP loss. For example, expenditure per capita in 2022-32 would be 55.2 percent of the 2005 level, compared with 48.7 percent (see Figure 8).

Figure I. 9. Preparing for Recession by Saving More, 2005-49

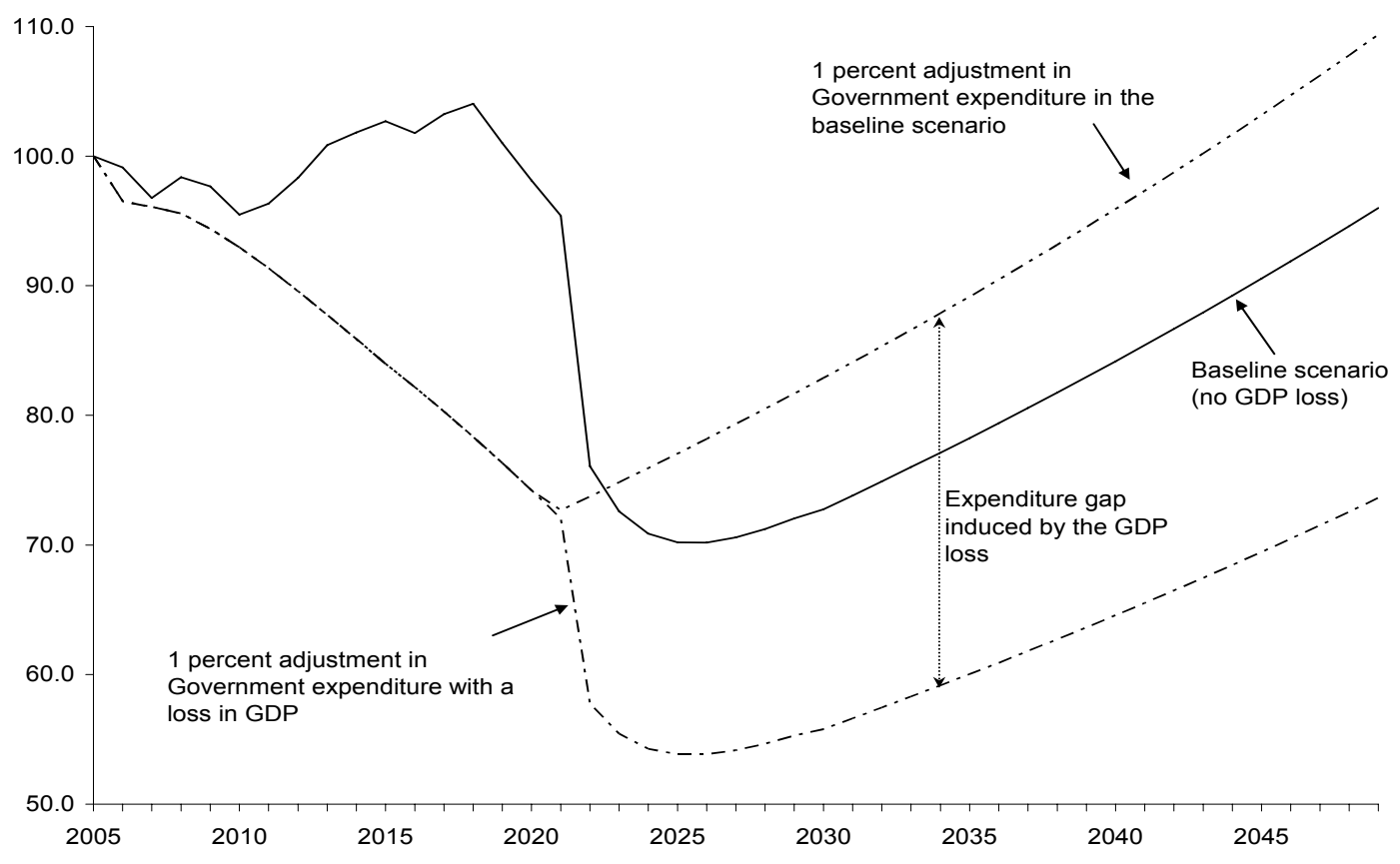


28. Another way to smooth the per capita expenditure would be to impose increase savings during the intial years of the transition (Figure 10). With an stronger adjustment in expenditure, namely a decrease by 2 percent of GDP until 2013, Botswana would be able to accumulate greater savings, which would.then be used after 2013 to avoid a too sharp decrease in per capita expenditure. However, since the short term effort would be a lot higher, it would require particularly strong political and social support in order to be implemented.

Figure I. 10. Alternative adjustment, 2005-49

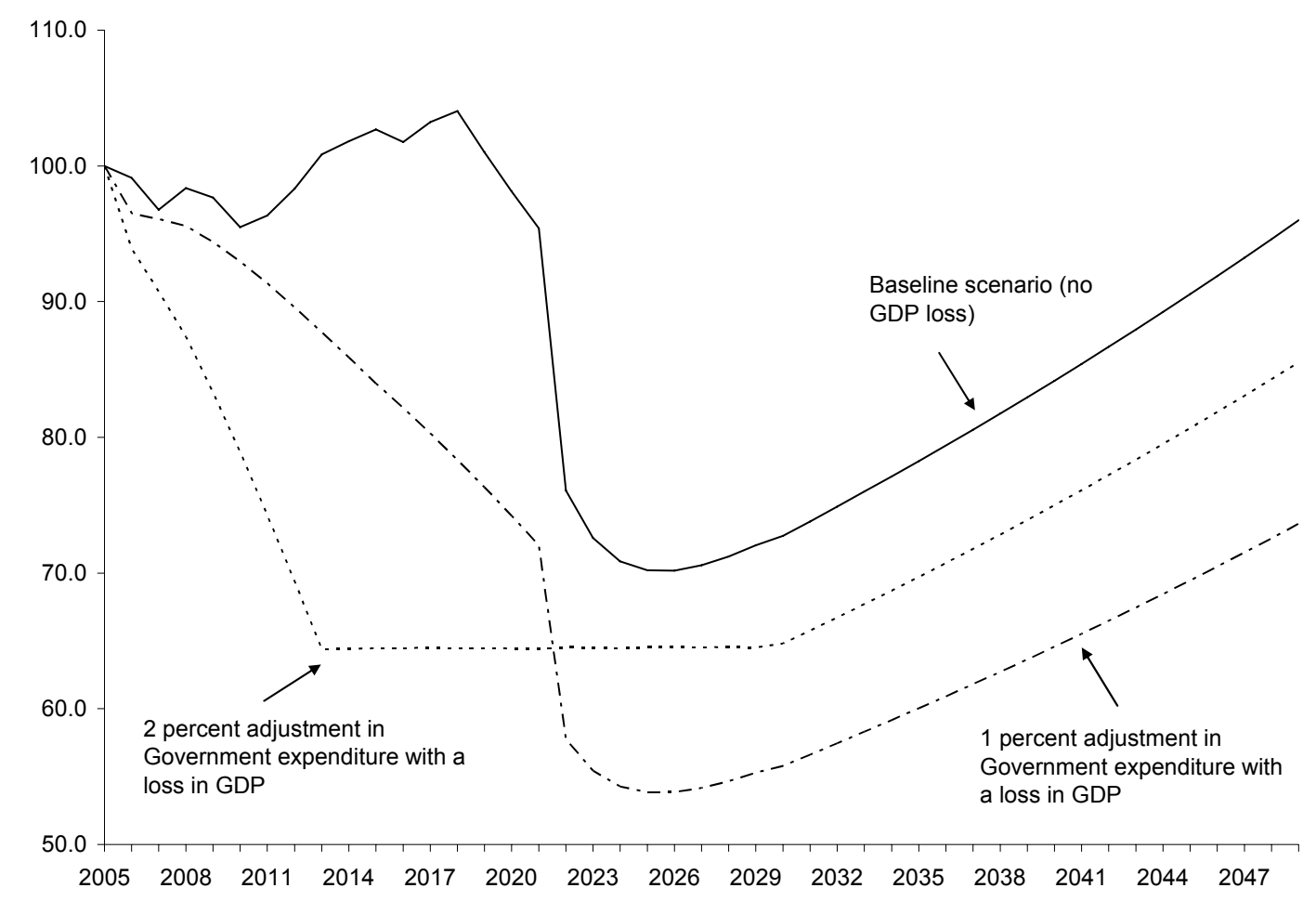

29. For simplicity, the precise link between diamond and nondiamond sectors and/or revenues are not explicitly modeled in this study. The purpose of this analysis is just to provide some benchmarks on the impact of no compensation for diamond production loss. However, if the economy fails to diversify, the fall of diamond production could spread to the rest of the economy, hence leading to a sharper recession. This would put the economy further below than the scenario with no compensation for GDP loss provided here, which reinforces the need for early adjustment and further diversifying the economy.

\section{F. Lessons from the Simulation Exercises and Sensitivity Analysis}

30. Diamond reserves are not adequate to generate enough permanent revenue to support the current level of expenditure. Under the current fiscal rule, i.e. no accumulation of debt, higher savings will be necessary in order to avoid a too sharp adjustment over the medium term. However several points should be underlined. 
- $\quad$ To be viable, higher savings in the short and medium term require a strong political consensus, given that the current economic situation does not require such an adjustment. Thus the viability of any adjustment will be judged by the ability of the authorities to gather a large political and social support for it, which could possibly imply further constraints to keep pro-poor expenditures per capita very stable in real terms.

- Economic diversification implies further attracting foreign investors, so as to improve the growth potential further. Moreover, new partnerships with the private sector could be considered for infrastructure financing.

- $\quad$ Budget contingency planning might be necessary to accommodate uncertainty about the actual stock of diamonds.

- The nondiamond fiscal deficit demands continued scrutiny. For example, if the nondiamond deficit widens, a tighter fiscal policy would be appropriate even if diamond-related revenue is high, precisely because of the economy cannot rely on diamond resources over the long term. Moreover, the nondiamond deficit might be associated with lower long-term growth (see Sachs and Warner, 2001, for a literature review of countries dependent on hydrocarbon resources).

- $\quad$ Finally, the nondiamond fiscal stance might be of better use for assessing the soundness of fiscal policy relative to the business cycle On the expenditure side, a greater focus on productivity would alleviate additional pressures on fiscal policy.

31. In conclusion, it should be also noted that the HIV/AIDS epidemic is likely to affect both the growth potential of the economy (by lowering it) and government expenditure (which would need to be increased). Although a specific analysis of these linkages is beyond the scope of this study, it reinforces the need for initiating the adjustment rapidly, since the epidemic could only complicate further the adjustment. 


\section{References}

Barnett S., and R. Ossowski, 2003, "Operational Aspects of Fiscal Policy in Oil-Producing Countries," in Fiscal Policy Formulation and Implementation in Oil-Producing Countries, ed. by J. Davis, R. Ossowski, and A. Fedelino (Washington: International Monetary Fund).

Davoodi, H. R., 2002, “Assessing Fiscal Vulnerability, Fiscal Sustainability, and Fiscal Stance in a Natural Resource-Rich Economy,” IMF Country Report No. 02/64: 7-31 (Washington: International Monetary Fund).

Friedman, M., 1957, A Theory of Consumption Function (Princeton, N.J.: Princeton University Press).

Modigliani, F., and R. Brumberg, 1954, "Utility Analysis and the Consumption Function: An Interpretation of Cross-Section Data," in Post-Keynesian Economics, ed. by Kenneth K. Kurihara (New Brunswick, N.J.: Rutgers University Press).

Sachs, J. D., and A. Warner, 2001, "The Curse of Natural Resources," European Economic Review, Vol. 45, pp. 827-38. 


\section{A Narrow Economy and High Unemployment, Twin Problems for Botswana ${ }^{5}$}

\section{A. Introduction}

32. Botswana, a resource-rich middle-income country, has been praised for its stable democratic government, rapid economic growth, and prudent management of its large diamond resources. However, the country is highly dependent on the diamond mining industry and a large government sector. While nondiamond exports have grown, diamonds still dominate exports at around 75 percent, most other exports are mining-related, and growth in the nonmining private sector is weak. Foreign direct investment (FDI) has been concentrated in the mining sector, which offers limited employment opportunities because it is capital-intensive.

33. Botswana's unemployment has been high, and as a result social indicators often lag behind those of other economies in similar income levels. Unemployment has been persistently above 20 percent, and the rate is rising, particularly among the young. The government has been the largest employer, and the main export industry, the mining industry, accounts for only 3 percent of formal employment. The result of high unemployment is that about a third of the population lives below the national poverty line (roughly comparable to $\$ 2$ a day), and the Gini coefficient is at almost 0.6, compared to 0.30.5 in most middle-income countries ${ }^{6}$. Botswana also has one of the highest HIV/AIDS infection rates in the world (about 35 percent of adult population, according to UNAIDS), which puts further pressure on social development and costs.

34. The purpose of this paper is to understand (i) why, despite global recognition of Botswana's institutional transparency and stable economy, the economy relies so heavily on diamonds and a large government sector; and (ii) why unemployment and poverty rates are high when the economy has been growing rapidly. It argues that the large size of the government causes two problems:

- $\quad$ Diamond revenues have allowed the government to become the largest employer with an average wage well above the rest of the economy. This may have tilted the workers' preference towards limited job opportunities in the government sector than to seek employment opportunities in the private sector.

- At the same time, the government has provided various types of social safety net programs. This, and financial support from extended families may have increased

\footnotetext{
${ }^{5}$ Prepared by Jung Yeon Kim.

${ }^{6}$ While absolute poverty is likely to have decreased since 1993 in light of Botswana's high growth rate, the increase in the unemployment rate and the only modest decline in the Gini coefficient suggest that high levels of relative poverty exist.
} 
their reservation wage: potential workers are unemployed because they are unwilling to work at a market-clearing wage.

35. The result is economic waste with high unemployment and employers, including potential foreign investors, offering fewer jobs than they otherwise would. Hence, FDI continues to be limited to the capital-intensive mining sector.

Table 1. Selected Social Indicators in 2002

\begin{tabular}{|c|c|c|c|c|c|}
\hline & Botswana & $\begin{array}{c}\text { Sub-Saharan } \\
\text { Africa } \\
\end{array}$ & SACU 2/ & $\begin{array}{c}\text { Upper-middle } \\
\text { income countries }\end{array}$ & $\begin{array}{c}\text { Lower-middle } \\
\text { income countries }\end{array}$ \\
\hline Rank in UNDP Human Development Index out of 175 countries 1/ & 128 & 152 & 129 & 80 & 131 \\
\hline GDP per capita (US\$, 2003 for Botswana) & $4,660.0$ & 464.0 & $1,363.5$ & $5,110.0$ & $1,184.0$ \\
\hline Population below US\$ 1 a day (percent, 2003 for Botswana) & 30.0 & 46.5 & 29.6 & $\ldots$ & $\ldots$ \\
\hline Adult literacy rate (percent) & 78.9 & 63.2 & 82.9 & 89.7 & 63.6 \\
\hline Net primary enrolment ratio (percent of relevant age group) & 81.0 & 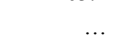 & 82.3 & 93.0 & $\ldots$ \\
\hline Infant mortality rate (per 1,000$)$ & 80.0 & 108.0 & 76.0 & 19.0 & 104.0 \\
\hline Fixed line and mobile telephones (per 1,000 people) & 328.0 & 54.0 & $\ldots$ & 344.0 & 45.0 \\
\hline Life expectancy at birth (years) & 41.4 & 45.8 & 41.5 & 73.0 & 59.2 \\
\hline
\end{tabular}

Sources: United Nations, Human Development Report 2004; WDI Database; and staff estimates

1/ Based on average of HDI value of group of countries except Botswana.

2/ Includes Lesotho, Namibia, South Africa and Swaziland.

\section{B. Sources for Botswana's Rapid Growth}

36. Botswana's per capita income rose from US\$80 at the time of its independence in the mid-1960s to US\$4,600 in 2005. The rapid growth has been attributed to a stable political environment, good governance, and the rich diamond resource.

37. Despite the magnitude of diamond revenues, there has been no domestic political instability or conflict over control of revenue in Botswana. First, the ethnic fighting that has wounded much of Africa has not been a problem because most of the people are ethnic Tswanas. Second, after independence, the central government established itself as the holder of mineral rights in all tribal lands, thereby establishing the authority of the state over the entire country. This has helped it to avoid regional conflict due to diamond deposit-led income differences between regions. ${ }^{7}$ Botswana has also been praised for its institutional transparency; it is ranked among the top 25 percent (the highest in Africa) in Transparency International's Corruption Perception Index. ${ }^{8}$

${ }^{7}$ See Acemoglu et. al (2001) and Transparency International (2006).

${ }^{8}$ Standard and Poor's and Moody's have both rated Botswana's sovereign credit at A (highest in Africa). 
38. Botswana is the largest diamond producer in the world by both carats and value. Its successful partnership with De Beers, the world's largest diamond mining company, has also contributed to the development of the mining sector. In 2004 Botswana's four major mines produced 31 million carats of diamonds, about 66 percent of total DeBeers Group output. The fact that Botswana's diamond deposits are in kimberlite pipes where diamonds are concentrated in a small area makes it much easier to secure the mines from diamond smugglers. This makes possible large-scale diamond production at low cost, which in turn contributes to high government revenues through corporate taxes, royalties, and profits from Botswana's 50 percent share in its joint venture with DeBeers (Debswana) and its 15 percent stake in DeBeers itself.

\begin{tabular}{lrrrr}
\hline \multicolumn{1}{r}{ Table 2. World Diamond Production Estimates (US\$ billion) } & 1/ \\
\hline \hline & 2001 & 2002 & 2003 & 2004 \\
Angola & 0.9 & 0.9 & 1.1 & 1.2 \\
Australia & 0.3 & 0.4 & 0.4 & 0.3 \\
Botswana & 2.3 & 1.8 & 2.2 & 2.9 \\
Canada & 0.6 & 0.6 & 1.0 & 1.4 \\
Namibia & 0.5 & 0.5 & 0.5 & 0.7 \\
Others & 0.5 & 0.4 & 0.5 & 0.7 \\
Russia & 1.8 & 1.5 & 1.6 & 2.0 \\
South Africa & 0.9 & 0.8 & 1.0 & 1.3 \\
D.R. Congo & 0.4 & 0.4 & 0.7 & 0.7 \\
\hline \multicolumn{1}{c}{ Total } & 8.2 & 7.3 & 9.0 & 11.2 \\
\hline \hline
\end{tabular}

Source: DeBeers

$1 /$ Estimates of the market value of rough production.

\section{Slow Diversification and High Unemployment}

\section{Progress on Economic Diversification}

39. Botswana's economy is dominated by two sectors, mining and government, and economic diversification has been slow. In 2005 the mining sector constituted 35 percent and the government 16 percent of GDP, shares that have not changed significantly over the last decade. Mining grew at an average annual rate of 5.1 percent and government at 6.2 percent between 1994/95 and 2003/04. Growth in other sectors has been minimal; it in fact decelerated from an annual average of 7 percent from 1984/85 to 1993/94 to about 1 percent in the following decade. Growth was particularly weak in the agricultural sector, which fell from about 10 percent of GDP in 1981 to about 2 percent in 2004/05. The manufacturing sector also slowed markedly, from about 13 percent in the previous decade to around 3 percent over the decade to 2004/05. During these two decades, growth in the construction sector slowed from 11 to 4 percent. The trade, hotels, and restaurants sector seems relatively resilient. It registered average annual growth about 7 percent — but this is also a significant drop from over 18 percent growth in the previous decade. 
40. FDI has been largely limited to the mining sector. Despite Botswana's liberal approach to trade and finance and its ranking in the top third in global competitiveness report (ahead of China, India, and Mexico) ${ }^{9}$, net FDI has been concentrated in diamond mining.
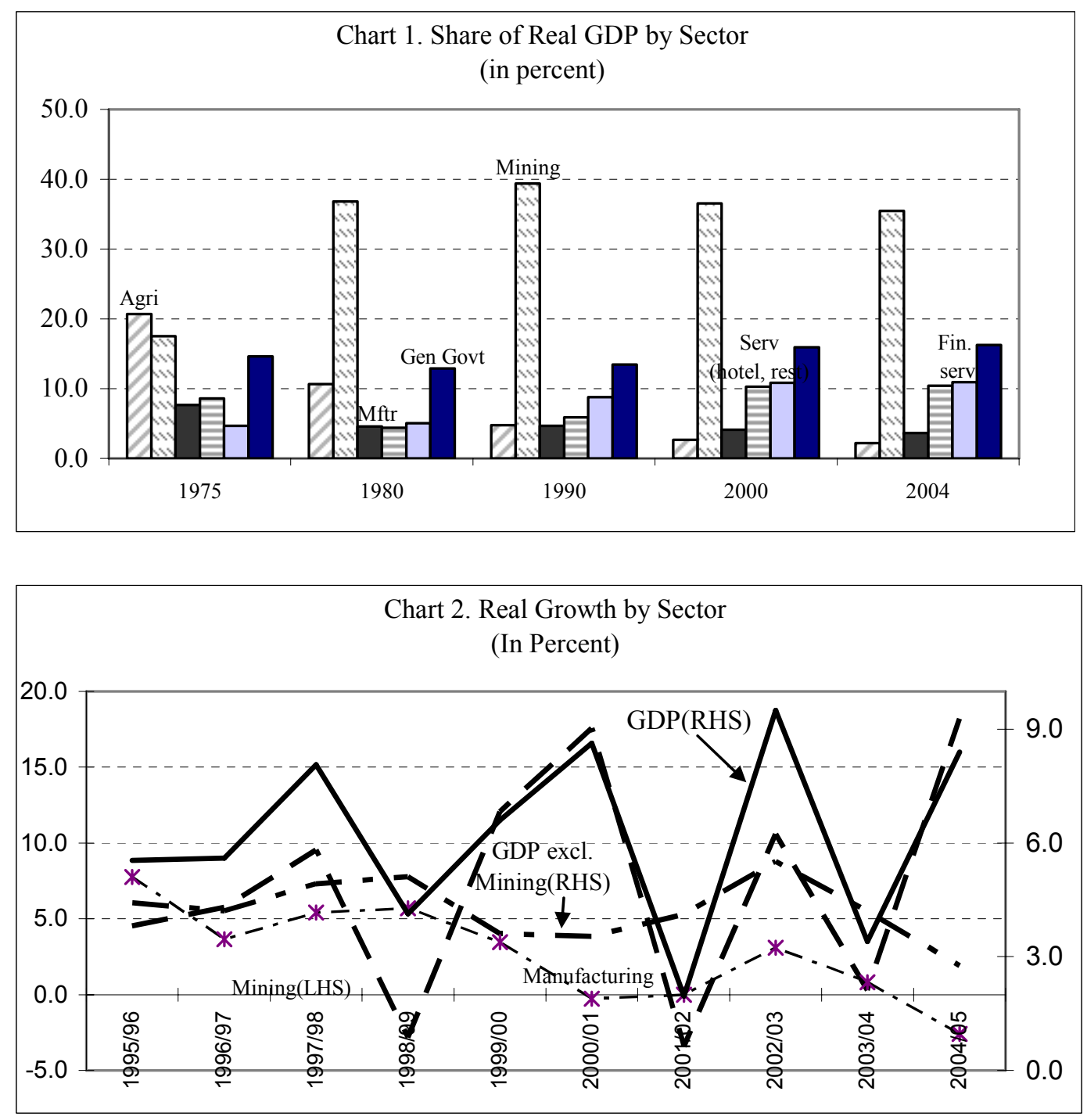

\section{The Size of Government}

41. The government plays a large role in Botswana's economy with government consumption accounting for roughly one quarter of GDP ever since the early 1980s. At the same time, the share of household consumption declined from about 60 percent of GDP to less than half that by $2004 / 05$. The government sector accounted for more than half of

${ }^{9}$ Global Competitiveness Report, 2004 by World Economic Forum. 
nonmining GDP in 2003/04. In particular, government development spending has given impetus to such sectors as construction while pushing domestic demand more generally. The government has also played a significant role in the domestic financial sector with budget surpluses being a major source of savings in the economy. Moreover, several publicly owned development finance institutions were established, and the Government was also engaged in substantial lending to parastatals and local authorities from its Public Debt Service Fund (PDSF) and Revenue Stabilization Fund (RSF). From the early 1980s to the late 1990s, total lending out of these funds was higher than the combined lending of all other financial institutions in Botswana. As the largest employer in the economy, the government was responsible for about 40 percent of total formal sector employment in the decade ending in 2004/05.

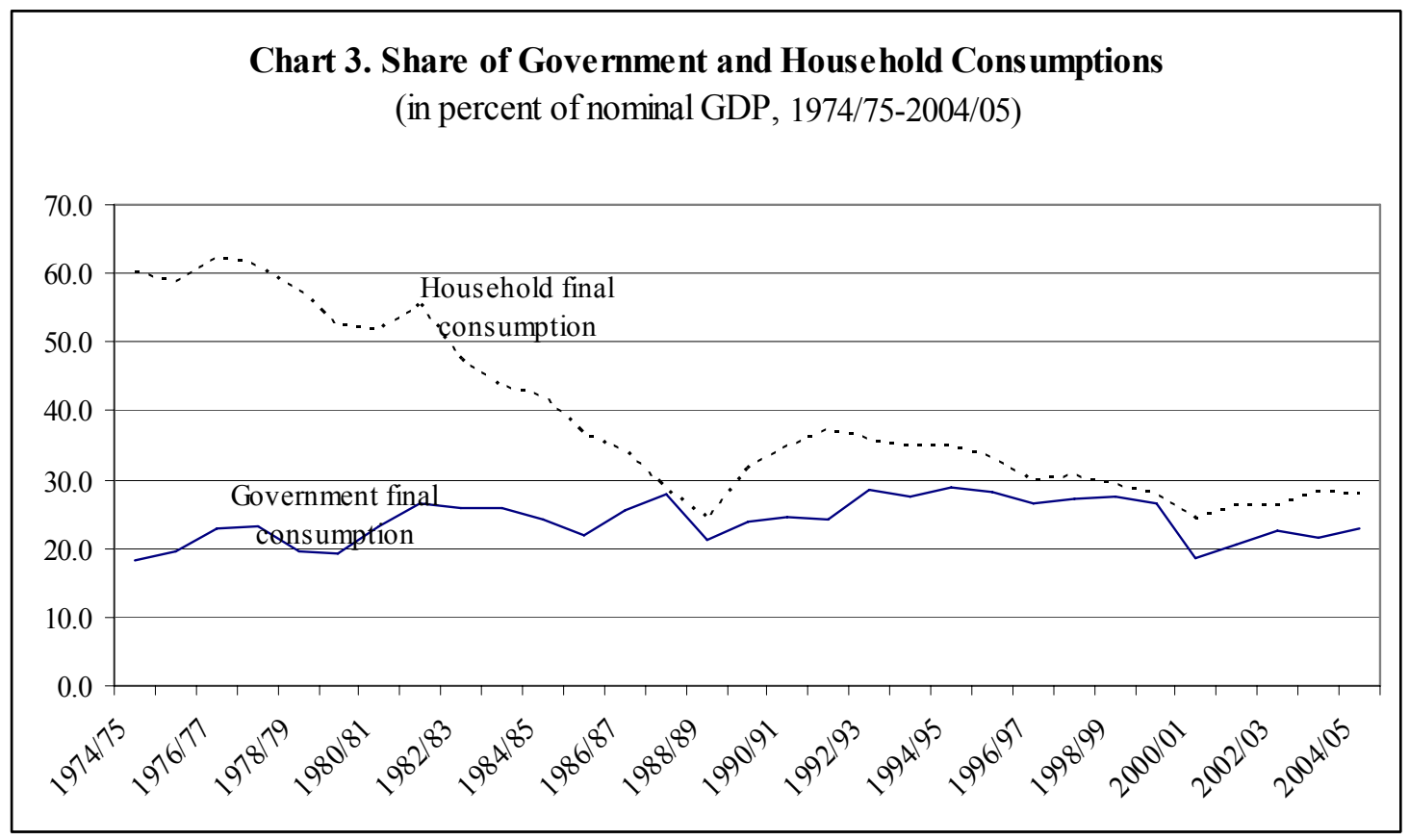

\section{E. Labor Market Conditions and Rising Social Problems}

42. Slow growth in the nonmining private sector has meant that growth in employment has not been sufficient to absorb the rising labor force. Based on the 2004 Botswana AIDS Impact Survey (BAIS), unemployment is estimated at about 24.6 percent, compared to an average of 12 percent among other countries in similar income level. ${ }^{10}$ While changes in methodology and coverage make intertemporal comparisons difficult, unemployment roughly doubled from the early 1980 s to exceed 20 percent by the early 1990 s through to the

${ }^{10}$ World Bank, 2006 World Development Indicators. 
present. Unemployment is highest among unskilled youth, at 60.8 percent for 15- to 19-yearolds and 45.6 percent for those aged 20-24. Yet significant shortages persist in more skilled occupations. Unemployment is higher in urban than rural areas, and female unemployment exceeded male by about 30 percent.

43. Botswana does not seem to have the kind of labor market rigidities often observed in European countries. The main law governing relations between employers and employees is the Employment Act of 1984 as amended, which prescribes minimum standards for contracts that apply to all employment relations. Depending on the reasons, the employer can even terminate employment contracts without notice. ${ }^{11}$ An employer can also lay off employees to reduce the size of the work force. Although there are binding sector-specific minimum wages, there is no unemployment insurance and the employer is not required to make pension, health insurance, and unemployment insurance contributions on behalf of the employee. Though labor unions exist, reportedly they are not aggressive in collective actions. Employers have stated that in general they do not see labor regulation as an impediment to doing business.

\section{F. Factors Underlying the Narrow Economic Base and High Unemployment}

44. This section attempts to provide some explanations for high unemployment and slow diversification in Botswana, with special attention to public employment and productivity. The fact that the large flow of diamond revenues allows the government to be the largest and a generous employer may unintentionally lead to twin problems for the labor market and economic diversification: (i) a rise in the reservation wage of workers results in high unemployment and poor social conditions, and (ii) the higher cost of production and low productivity, low FDI inflow, and slow private sector-led growth, industrialization and diversification.

\section{Employment and Wages in the Public Sector}

45. The 42 percent of Botswana's formal-sector workers employed by the government claimed over 50 percent of total formal sector wage earnings in 2005. Though large public sector employment has been observed in some other countries in Anglophone Africa, in Botswana it is more pronounced (see table 3).

46. The government wage expenditure has increased significantly over the past decade. It rose on average by 13.3 percent annually from $1995 / 96$ to $2004 / 05$, though average annual inflation was just 8.2 percent. As a result, in 2005 the average wage of citizens working for the government exceeded those in the private sector and parastatals by over 40 percent. The

\footnotetext{
${ }^{11}$ Prior written notice of termination must be given unless the employee is paid per day, is in the probation period, or is guilty of serious misconduct.
} 
contrast is even more stark when the parastatals are eliminated. Total public wage expenditure for 2004/05 constituted almost 30 percent of public spending ${ }^{12}$ (12 percent of GDP). Botswana's public wage-GDP per capita ratio, which indicates whether government employees are under- or overpaid in comparison to the prevailing standard of living, is also considerably higher than in other middle-income countries. ${ }^{13}$ Moreover, it appears that the wage differential between public and private sectors widens at the lower end of the wage scale, making it more desirable for less skilled workers to work for the public sector.

Table 3. Average Monthly Cash Earnings of Botswana Citizens by Sector, 1998-2004

(In Pula)

\begin{tabular}{|c|c|c|c|c|c|c|c|c|}
\hline & $\begin{array}{l}\% \text { share in } \\
\text { total formal } \\
\text { employment }\end{array}$ & 1998 & 1999 & 2000 & 2001 & 2002 & 2003 & $20041 /$ \\
\hline Private and parastatal & 57.5 & 1,067 & 1,243 & 1,605 & 1,414 & 1,560 & 1,719 & 2,141 \\
\hline Private & 53.1 & $\ldots$ & $\ldots$ & $\ldots$ & $\ldots$ & $\ldots$ & $\ldots$ & 1,765 \\
\hline Paraastatal & 4.4 & $\ldots$ & $\ldots$ & $\ldots$ & $\ldots$ & $\ldots$ & $\ldots$ & 6,702 \\
\hline Agriculture & 1.6 & 346 & 383 & 434 & 409 & 563 & 542 & 697 \\
\hline Mining and quarrying & 3.1 & 1,950 & 2,249 & 3,010 & 2,423 & 3,206 & 3,362 & 4,518 \\
\hline Manufacturing & 10.8 & 632 & 785 & 1,096 & 835 & 849 & 944 & 1,219 \\
\hline Electricity and water & 0.8 & 2,043 & 3,166 & 3,616 & 3,525 & 4,517 & 5,569 & 6,124 \\
\hline Construction & 8.0 & 754 & 776 & 1,006 & 917 & 997 & 1,050 & 1,138 \\
\hline Commerce & 18.7 & 867 & 953 & 1,001 & 1,179 & 989 & 1,253 & 1,533 \\
\hline Transport and communications & 4.1 & 1,725 & 2,318 & 2,689 & 2,616 & 3,510 & 3,597 & 3,585 \\
\hline Finance and business services & 6.8 & 1,593 & 1,979 & 2,164 & 2,251 & 3,056 & 3,080 & 3,336 \\
\hline Community and personal services & 1.6 & 1,249 & 1,413 & 1,669 & 1,660 & 1,998 & 1,965 & 2,472 \\
\hline Education & 2.1 & 1,983 & 2,261 & 3,069 & 2,775 & 2,895 & 2,830 & 5,010 \\
\hline Government & 42.5 & 1,334 & 1,512 & 1,747 & 1,952 & 2,336 & 2,447 & 2,694 \\
\hline Local government & 33.8 & 1,190 & 1,496 & 1,732 & 1,948 & 1,866 & 2,502 & 2,545 \\
\hline Central government & $\begin{array}{r}8.6 \\
100.0\end{array}$ & 1,566 & 1,733 & 2,001 & 2,232 & 2,804 & 2,781 & 3,122 \\
\hline
\end{tabular}

Source: Central Statistics Office

1/ 2004 data based on sources from Ministry of Labour and Home Affairs.

${ }^{12}$ As a rule of thumb, when this ratio rises above 25 percent, governments risk reducing their effectiveness by squeezing nonwage expenditure for goods and services, maintenance, and capital investments.

${ }^{13}$ This is common in developing countries where the number of dependents per wage earner is large, trained labor is scarce, and the standard of living is low. 
Table 4. Public sector in the labor market

\begin{tabular}{lrrr}
\hline & $\begin{array}{c}\text { GDP per capita } \\
(2004, \text { US\$) }\end{array}$ & $\begin{array}{r}\text { Public employment } \\
(\% \text { of total) }\end{array}$ & Public wage/GDP per capita \\
\hline Chile & 5,220 & 16.3 & 0.1 \\
Mauritius & 4,640 & 19.0 & 1.4 \\
Malaysia & 4,520 & 8.6 & $\ldots$ \\
Costa Rica & 4,470 & 14.1 & 0.2 \\
Botswana & $\mathbf{4 , 3 6 0}$ & $\mathbf{4 3 . 7}$ & $\mathbf{2 . 7}$ \\
South Africa & 3,630 & 34.3 & 0.3 \\
Thailand & 2,490 & 8.1 & $\ldots$ \\
Namibia & 2,380 & $\ldots$ & 3.4 \\
\hline Source:
\end{tabular}

Source: ILO Laborstat 2006

\section{Industrialization in nonmining sector}

47. In Botswana, unlike many newly industrialized economies, nonmining manufacturing has not been a dynamic labor absorber. Rather, its share in GDP has been declining. Some efforts have been made in the past to boost the textile industry and take advantage of access to the U.S. market under the African Growth and Opportunity Act (AGOA), but this has become difficult now due to strong competition from other developing countries. The manufacturing sector took an upturn when the Motor Company Botswana (Hyundai) opened its plant, but this was soon closed in 2002/03.

48. Botswana's proximity to neighboring giant South Africa may also have deterred efforts to build the manufacturing sector. South Africa, with its large domestic market and abundant labor supply, has a strong competitive advantage over Botswana; it may be cheaper for Botswana to import from South Africa than to manufacture goods domestically. For example, many automobile manufacturing plants based in South Africa service the whole continent.

49. The large diamond endowment and subsequent reliance on natural resources may have diminished its need to coordinate labor supply and demand, which can slow down industrialization. Rich natural resources can lessen political incentive to pursue difficult policies to build a labor-intensive nonmining manufacturing export sector. Experiences from emerging market countries show that resource-poor countries tend to grow through internationally competitive industrialization. ${ }^{14}$ Their governments tend to abandon closed trade policies at a low per capita income and, since commodity exports are limited, laborintensive manufactured exports expand rapidly and soon absorb excess labor. This allows the economy to diversify within the skill-intensive manufacturing sector and later to enter into competitive capital-intensive industries so that the economy becomes more resilient to external shocks. The early elimination of surplus labor and the incentives from competitive manufacturing curb unemployment and boost saving and investment. Low unemployment

14 "The East Asian Miracle-Economic Growth and Public Policy", 1993, The International Bank for Reconstruction and Development, The World Bank . 
leads to improvement in income inequality. In Botswana, on the contrary, unemployment remains stubbornly above 20 percent, one of the highest rates among middle-income countries.

\section{Reservation Wage}

50. A large government employment share and generous government wages may have raised the reservation wage of workers. Workers may be unwilling to work unless they receive salaries well in excess of the market clearing level in the rest of the economy. This can continue for relatively long periods if dependence on extended families for financial support can allow unemployment to persist.

51. Concerns about a rising reservation wage despite high unemployment have been expressed by the authorities on several occasions. These are expressed in the Mid-Term Review of National Development Plan (NDP) 9, paragraph 86, as well as the 2006 Budget Speech by the Minister of Finance and Development Planning, paragraph 21, which states, "... Botswana workers have become selective in the jobs they are willing to accept, choosing instead to rely on relatives or social safety nets". The authorities have indicated that young university graduates often desire only white-collar jobs, the availability of which is becoming more limited as private sector-led economic diversification is slow. Employers needing workers with less skill have had to hire noncitizens who were willing to accept the jobs and the wages citizens have refused.

52. The social programs in Botswana may also have contributed to a relatively high reservation wage (See Table 5). Social programs in Botswana target a large population. While these are mostly people too old or too young to be in the labor force, the programsfrom which about a third of the population benefit - may indirectly provide incentives to dependency, as can be inferred by the rising number of welfare beneficiaries and the high unemployment despite solid economic growth. Government expenditure on social programs more than doubled from 1997/98 (P1.4 billion) to 2004/05 (P3.2 billion). This may have positive implications because more people are elevated from absolute poverty, and it also signals that when all government programs are considered, the effective poverty level may not be as severe as some international indices suggest. Until very recently, the government provided free health care and education to its entire people. However, the rising number of social program beneficiaries, the increasing share of social in total expenditure, and continuing HIV/AIDS-related expenditure are putting pressure on government finances at a time when medium-term growth and the fiscal envelope are likely to become more constrained. Appropriate responses to the situation would be to broaden labor force participation, reduce the dependency ratio, and design policies to reduce unemployment. 


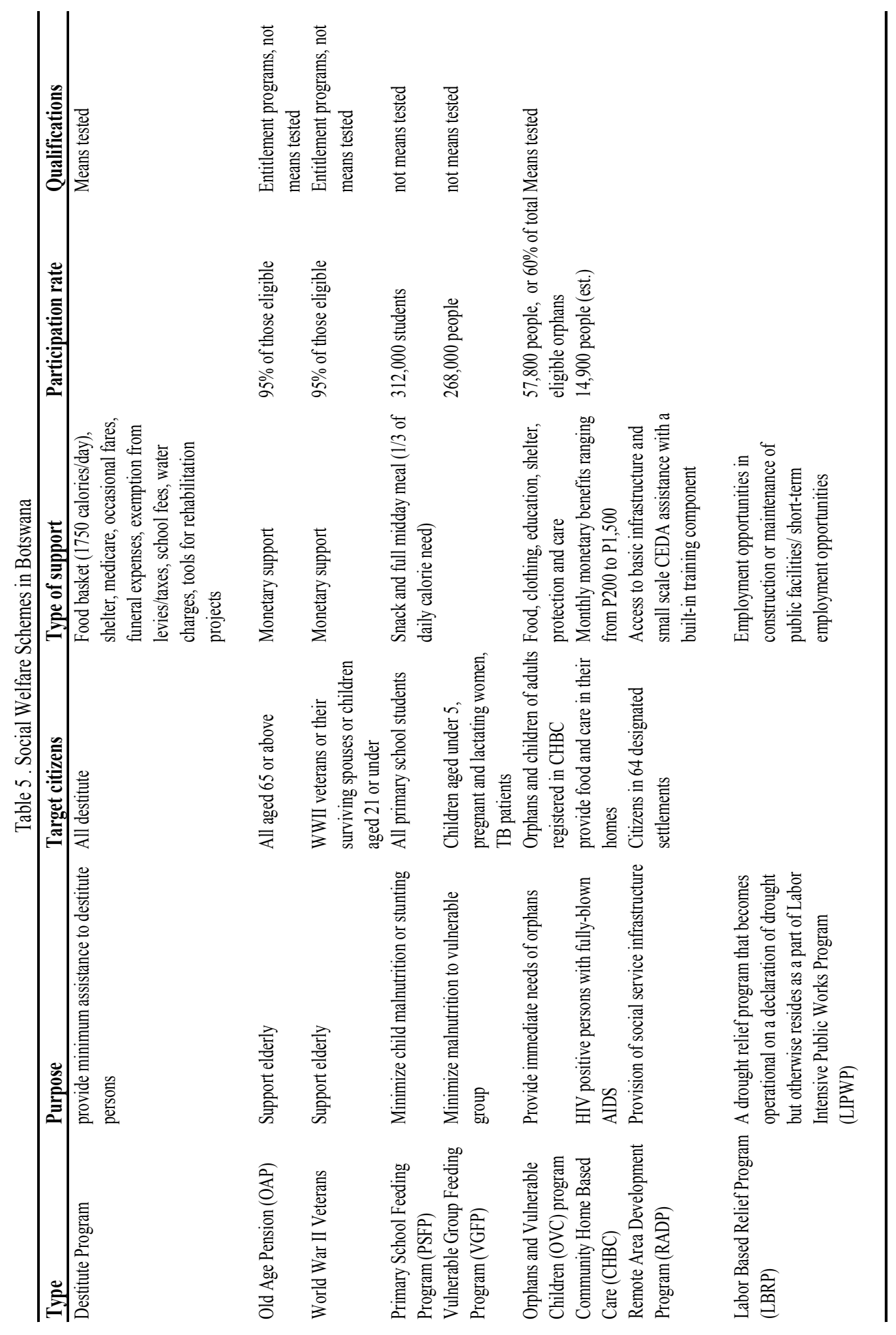




\section{Production Costs, Productivity, and FDI}

53. Botswana has followed textbook macroeconomic advice on attracting investment inflows, which are an important source of knowledge spillover and industrialization, increases in employment, and human capital development. That may be why it is ranked highest in Africa for competitiveness and institutional transparency (Table 6).

Table 6. Indices of International Competitiveness

\begin{tabular}{llll}
\hline $\begin{array}{r}\text { Corruption Percention Index, 2004 } \\
\text { by Transparency International }\end{array}$ & $\begin{array}{c}\text { Global Competitiveness Report, 2004 } \\
\text { by World Economic Forum }\end{array}$ & $\begin{array}{c}\text { Africa Competitiveness Report, 2004 } \\
\text { by World Economic Forum }\end{array}$ & $\begin{array}{c}\text { Africa Public Institutions Index, 2003 } \\
\text { by World Economic Forum }\end{array}$ \\
\hline \hline 1. Finland & 1. Finland & 1. Botswana & 1. Botswana \\
2. New Zealand & 2. United States & 2. Tunisia & 2. Tunisia \\
3. Denmark & 3. Sweden & 3. South Africa & 3. Gambia \\
5. Singapore & 6. Norway & 4. Mauritius & 4. South Africa \\
15. Germany & 7. Singapore & 5. Namibia & 5. Mauritius \\
17. United States & 45. Botswana & 6. Gambia & 6. Egypt \\
31. Botswana & 47. Italy & 7. Egypt & 7. Tanzania \\
77. Morocco & 66. Turkey & 8. Morocco & 8. Ghana \\
90. Tanzania & 76. Philippines & 9. Tanzania & 9. Algeria \\
144. Nigeria & 93. Nigeria & 10. Ghana & 10. Morocco \\
\hline
\end{tabular}

54. Nevertheless, FDI inflow into Botswana is small and mostly concentrated in the mining sector. Larger FDI flows have been going to South Africa, where the size of domestic market is large. This highlights the importance of two factors on which multinational enterprises base their FDI decisions: (i) anticipated profit, which incorporates production cost, and (ii) market access. Since its utility and transportation costs are high because geographical location, other costs of production must be sufficiently low if Botswana is to attract foreign investors. However, as the authorities have noted in the Mid-Term Review of NDP 9, reducing production costs is difficult because Botswana lacks a local entrepreneurial culture and productivity generally is low. The Minister of Finance's 2005/06 budget speech also cites concerns about worker productivity and work ethics to enhance its competitiveness.

55. Low productivity in the nonmining sector may be both the cause and the effect of slow economic diversification. Productivity indicators illustrate that productivity improvement in most sectors other than mining has been modest at best. In particular, as indicated in the recent study by Botswana National Productivity Centre, the productivity trends in manufacturing, which have been negative since NDP 8 period (1997-2003), have worsened in recent years (see Table 7). Both labor and capital productivity declined significantly during this period. While output grew only about 5.8 percent from 1998 to 
2003, employment increased by 31.2 percent and the average monthly wage by almost 50 percent in nominal terms.

56. Higher costs mean that potential employers offer fewer jobs than they otherwise would. They also discourage the inflow of FDI, since in addition to its small market and high utility and transportation costs, Botswana's labor force may be less attractive to foreign investors than the labor force in countries where people are willing to work for less. Hence, FDI continues to be concentrated in the capital-intensive mining sector, which does little to generate employment and reduce poverty.

Table 7. Average Annual Growth Rates of Multifactor Productivity by Sector 1/

\begin{tabular}{lcccccc}
\hline & Mining & Manufacturing & Construction & Commerce & $\begin{array}{c}\text { Finance/ } \\
\text { business service }\end{array}$ & $\begin{array}{c}\text { Business } \\
\text { (non-farm, } \\
\text { non-mining) }\end{array}$ \\
\hline NDP 5 2/ & 12.1 & -11.0 & 5.0 & -1.2 & 4.1 & -5.6 \\
NDP 6 & 0.3 & 0.6 & -0.2 & 6.5 & 6.0 & 3.6 \\
NDP 7 & 0.5 & 1.2 & 0.5 & 11.6 & 0.5 & 3.4 \\
NDP 8 & 4.0 & -1.6 & -0.4 & 0.6 & 2.0 & 1.1 \\
2003/04 3/ & 4.1 & -3.0 & 2.4 & -1.7 & 1.5 & 0.0 \\
\hline
\end{tabular}

Source: Botswana Productivity Statistics, 2005

1/ Multifactor productivity is derived using a chain-based index involving weighting of labor input, capital input and real output.

2/ Reference years pertaining to NDP are as follows. NDP 5: 1979-85, NDP 6:1985-91, NDP 7: 1991-97, NDP 8: 1997-03, and NDP 9: 2003-09.

3/ Provisional.

\section{G. Conclusion and Policy Implications}

57. This paper argues that in Botswana, unemployment and slow economic diversification are two sides of the same coin, arising from rich endowment of natural resources and large government. Sizable revenue from diamonds may have made it difficult for the government to follow through on painful labor market reform. Instead, the government has been the largest employer both in size and in wages as a share in the economy. This, combined with financial support from extended families, may raise the reservation wage of workers. Low productivity is another factor; it raises production costs and discourages inflow of FDI, an important source of knowledge spillovers and diversification. Thus, despite strong overall growth, in Botswana a pattern of dependence on diamond revenue and high unemployment persists.

58. Botswana's twin problems can be solved only by long-term strategies to transform the economy. These must be directed to (i) reducing the size of government, (ii) expanding education and vocational training programs to raise the skill level of workers and to meet labor market demands, (iii) enhancing the efficiency of social welfare programs and devising exit strategies, and (iv) creating incentives for FDI inflow by reforming the labor market. 
While these categories are by no means complete, they could be a good start. Recognizing the needs, the government has already begun to formulate and apply remedial policies.

\section{Reducing the size of government}

- $\quad$ Reducing the total number of government employees is particularly important for local governments. The authorities have begun to limit the growth of new positions by hiring new employees only when an existing post becomes vacant. They also indicated that government wages would be adjusted by only half the inflation rate from 2006

- $\quad$ The government might continue to actively pursue outsourcing of services, especially those that require less lower skill.

\section{Education and vocational training adapted to labor market demands}

- $\quad$ Labor and education policies might be designed to increase the number of experts and technicians with skills industry needs. The government is proceeding with plans to establish a university specializing in science and engineering.

- $\quad$ More vocational schools should be established and technical programs developed to attract youth.

\section{Social welfare program efficiency and exit strategies}

- The government could aim to better target the beneficiaries of welfare programs to reduce dependency and the cost of programs. Welfare programs should be means tested and should provide incentives to graduate from them.

\section{Labor market reform to attract FDI inflow}

- Improvement in labor productivity is key to attracting foreign investors. Both public and private sector entities might introduce the Performance Management System already implemented in certain government positions to enhance competition among workers. The government could also implement social campaigns to improve the perception of blue collar jobs and improve the work ethic. 
References

Acemoglu D., S. Johnson, J. Robinson, 2001, "An African Success Story: Botswana," MIT Department of Economics Working Paper 01-37

Bank of Botswana, 2004, Annual Report (Gaborone).

Bank of Botswana, 2005, Annual Report (Gaborone)

Botswana National Productivity Centre, 2005, Botswana Productivity Statistics (Gaborone).

Botswana Institute for Development Policy Analysis, 2005, BIDPA Briefing, $1^{\text {st }}$ Quarter (Gaborone).

Citizen Entrepreneurial Development Agency, 2005, CEDA Annual Report (Gaborone).

Minister of Finance and Development Planning, 2006, Budget Speech (Gaborone). , 2006, Mid-Term Review of NDP-9, March 2006 (Gaborone).

Ministry of Local Government Lands and Housing, Social Welfare Division, 1998, Short-Term Plan of Action on Care of Orphans in Botswana, 1999-2001 (Gaborone).

Transparency International, 2005, Corruption Perceptions Index (Berlin: Transparency International)

World Bank [IABD], 1993, The East Asian Miracle-Economic Growth and Public Policy Bank (Washington: World Bank). 


\section{A Note ON INFLATion}

\section{A. Introduction ${ }^{15}$}

1. Botswana's annual inflation rate has averaged 7-9 percent since the mid-1990s, despite a period of historically low inflation among its main trading partners, South Africa, the United States, and the United Kingdom (Table III.1). In 2005, year-on-year inflation exceeded single digits, reaching a 13-year high of 14 percent by April 2006, triggered by the May 2005 pula devaluation, high international oil prices, and one-off factors.

2. This note explores Botswana's recent inflation developments, focusing on monetary aggregates and the exchange rate, the most powerful long-run determinants of Botswana's inflation rate. Using a unit-root econometric technique, we estimate a simple reduced-form inflation equation with quarterly 1993-2005 data. According to the results, South African inflation has the greatest influence on price movements in Botswana. The paper also finds that, while both exchange rate depreciation against the South African rand and monetary expansion are inflationary, the impact of exchange rate depreciations is much larger.

Table III.1. Annual Inflation, 1993-2005

(Percent; period average)

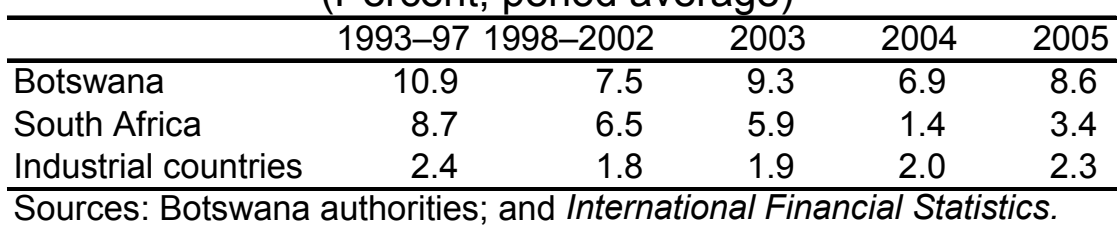

\section{B. Inflation Trends in Botswana, 1993-2005}

3. After the high inflation of 1992-93, Botswana experienced gradual disinflation towards 6 percent until recently, despite some inflationary pressures, including high international oil prices owing to the 1999 cuts in OPEC crude oil production and a new value-added tax (VAT) in 2002 (Figure III.1). While inflation for fuel and power items peaked at 251/2 percent in mid-2000, the 10 percent VAT pushed overall inflation to 12 percent by mid-2003.

4. More recently, inflation has trended downward, falling to 6 percent in early 2005 . However, two factors - a 12 percent devaluation of the national currency against the basket and the May 2005 introduction of a crawling peg-once again pushed inflation beyond the

\footnotetext{
${ }^{15}$ Prepared by Atsushi Iimi (AFR).
} 
authorities' targeted 4-7 percent range. On May 29, 2005, the Botswana government devalued the pula by 12 percent against the basket (comprising the South African rand and the SDR) and adopted a forward-looking crawling peg exchange rate arrangement, in which the pula's exchange rate to the basket would adjust continuously rather than in steps. ${ }^{16}$ It also increased the margin between the buy and sell rates for currencies quoted by the Bank of Botswana (from \pm 0.125 percent to \pm 0.5 percent around the central rate). By year-end 2005 , inflation had risen to about 11 percent. Additional inflationary pressures, including higher administered fuel and transport prices and the reintroduction of secondary education fees, pushed inflation to about 14 percent in the first half of $2006 .^{17}$

Figure III.1. Inflation, Jan. 1993-May 2006

(12-month percentage change)

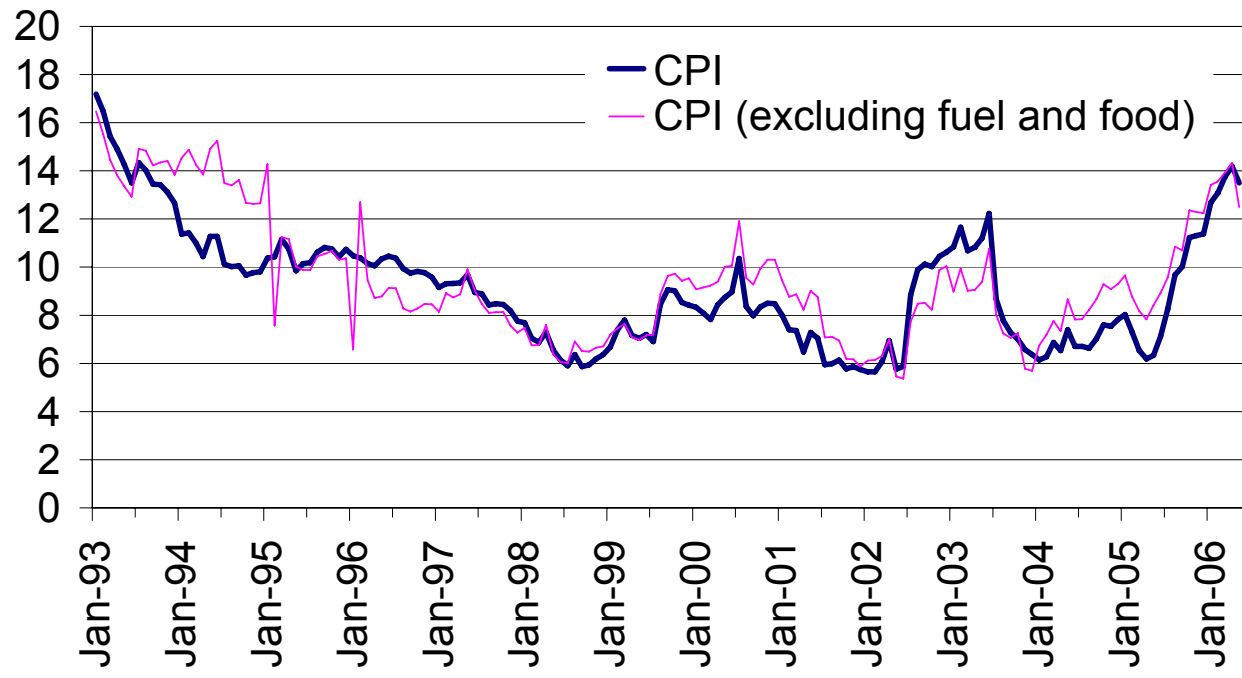

Sources: Botswana authorities; and Fund staff estimates.

5. The underlying relationship between inflation and growth in monetary aggregates has been weak, possibly owing to time lags in the transmission of monetary policy and noisy data. In the 1993-98 disinflation period, for instance, monetary aggregates generally increased. The M1 12-month growth rate peaked at about 50 percent in November 1998, and broad money (M3) grew more than 30 percent at the end of 1998 (Figure III.2). In contrast,

\footnotetext{
${ }^{16}$ According to a government press release, "the rate of crawl [will] be reviewed from time to time to align it with the differential between the expected rate of inflation in Botswana and the expected rate of inflation in the currencies of the basket" (May 29, 2005).

${ }^{17}$ The Bank of Botswana (BoB) raised its policy lending rate, Bank Rate, by $1 / 4$ percent in August and October 2005 and by $1 / 2$ percent in February 2006.
} 
when inflation picked up in 1999-2000, the growth in monetary aggregates quickly shrank. Since 2001, the monetary aggregates have been highly volatile, moving independently of the price level.

Figure III.2. Inflation and Monetary Growth, Jan. 1993-May 2006 (12-month percentage change)

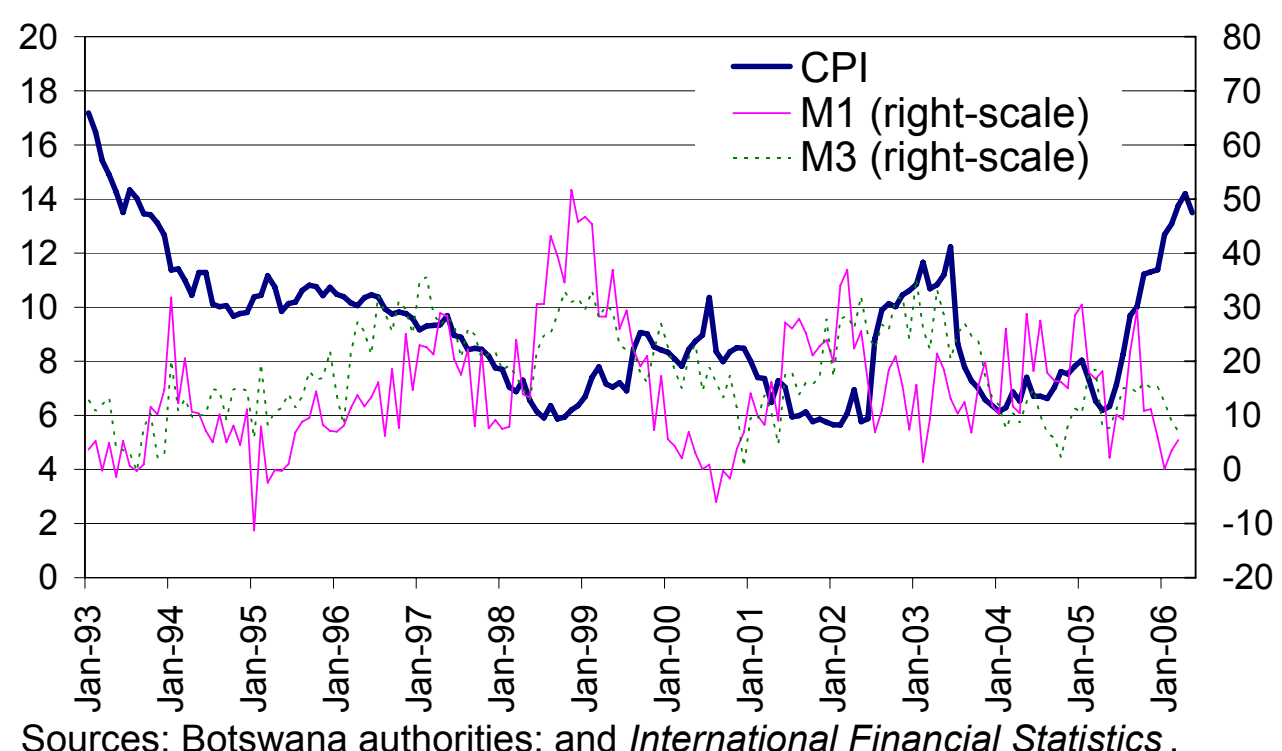

Sources: Botswana authorities; and International Financial Statistics .

6. Given that Botswana is a small open economy, one might expect inflation to be influenced by exchange rate movements. Botswana's current consumption basket is 24 percent domestic tradables, 47 percent imported tradables, and 29 percent nontradables. As shown by the data, exchange rate depreciations against the South African rand (Botswana imports most of its household goods and food from South Africa) seem to have played an essential role in explaining changes in the country's domestic prices, especially since 1995 (Figure III.3 and Table III.2). 
Figure III.3. Inflation and Exchange Rate against the Rand: Jan. 1993-May 2006

(12-month percentage change)

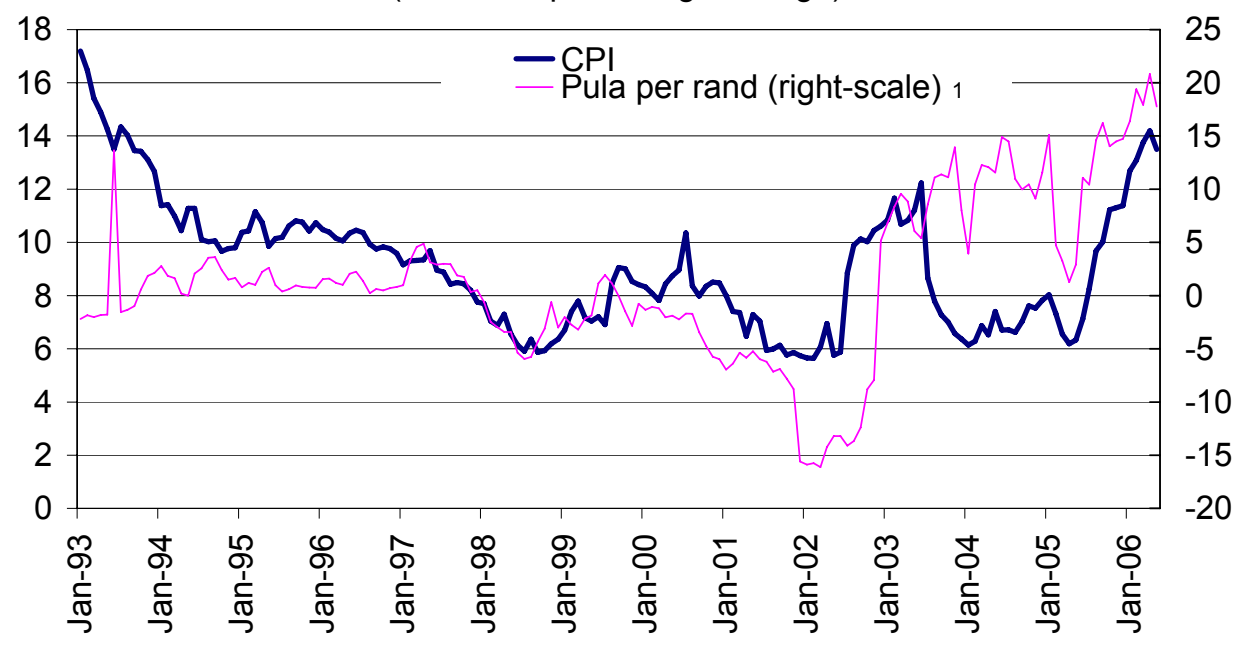

Sources: Botswana authorities; and International Financial Statistics .

${ }^{1}$ The exchange rate is shown in pula per foreign currency terms.

Table III.2. Correlation between Inflation and Exchange Rate Depreciation

\begin{tabular}{lrrrr}
\hline Period & Rand & US\$ & Euro & SDR \\
\hline Jan. 2003-May 2006 & 0.28 & 0.10 & -0.05 & 0.06 \\
Jan. 1993-Dec. 1994 & -0.41 & 0.17 & -0.70 & -0.47 \\
Jan. 1995-Jun. 2003 & 0.64 & -0.51 & -0.22 & -0.45 \\
Jul. 2003-May 2006 & 0.64 & 0.68 & 0.53 & 0.48 \\
\hline
\end{tabular}

Source: Author estimations.

7. By contrast, only recently have changes in the exchange rate against major industrial country currencies, such as the U.S. dollar and the euro, affected Botswana's inflation rate (Figure III.4). The relationship, after being fairly weak, appears to have strengthened in the past three years, according to a simple correlation of inflation and the pula's depreciation against the U.S. dollar (about 0.7) and against the euro (0.5) (Table III.2). Similarly, after appearing to move independently of domestic inflation, the pula-SDR exchange rate, which comprises part of the currency basket of Botswana, has demonstrated a certain correlation with inflation in recent years (Figure III.5 and Table III.2). 
Figure III.4. Inflation and Exchange Rates against the US\$ and Euro:

Jan. 1993-May 2006

(12-month percentage change)

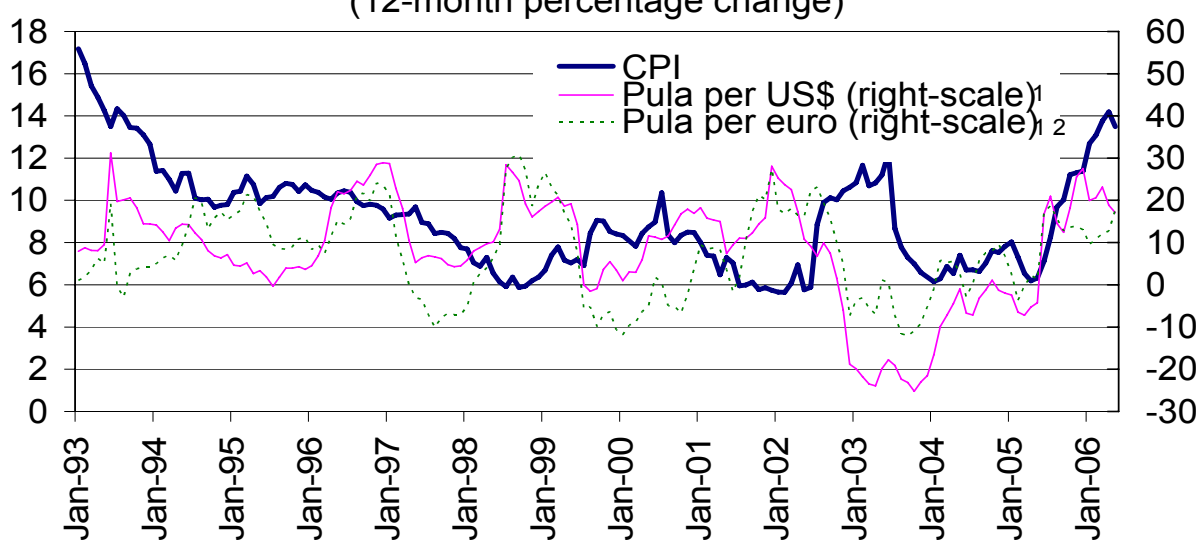

Sources: Botswana authorities; and International Financial Statistics .

${ }^{1}$ The exchange rates are shown in pula per foreign currency terms.

${ }^{2}$ The ECM was replaced with euro at a 1:1 rate in January 1999.

Figure III.5. Inflation and Exchange Rate against the SDR: Jan. 1993-May 2006

(12-month percentage change)

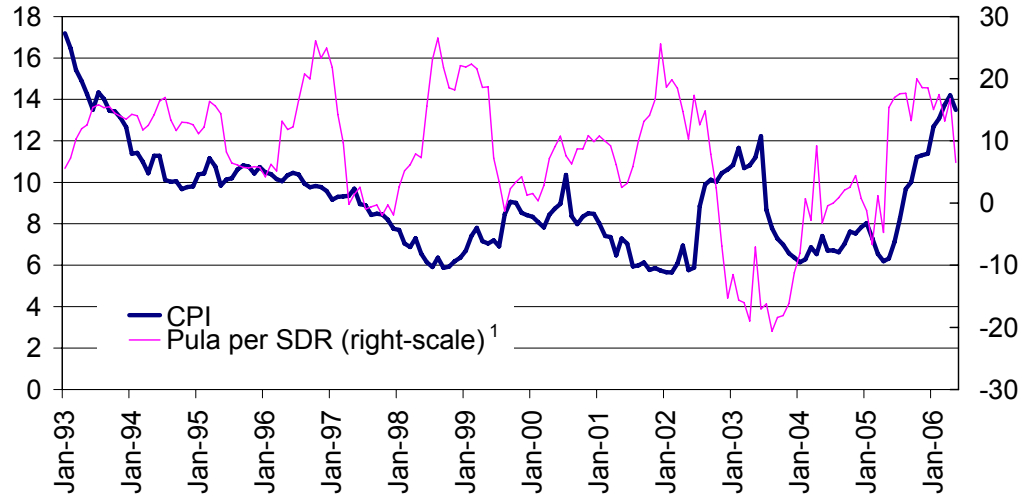

Sources: Botswana authorities; and International Financial Statistics .

${ }^{1}$ The exchange rate is shown in pula per foreign currency terms.

\section{Empirical Model and Data}

\section{Vector error-correction (VEC) model}

8. To explore the relationship between money, the exchange rate, real GDP, interest rates, and prices, we estimate a simple inflation model. The price level $(C P I)$ is, in general, a weighted average of tradable prices $\left(C P I^{T}\right)$ and nontradable prices $\left(C P I^{N}\right):{ }^{18}$

\footnotetext{
${ }^{18}$ The derivation of the empirical model in this note depends on Nassar (2005). Also see Gasha (2003), Kuijs (2000), Muñoz (2005), and Williams and Adedeji (2004).
} 


$$
\ln C P I=\lambda \ln C P I^{T}+(1-\lambda) \ln C P I^{N},
$$

where $\lambda$ is the weight of tradables in the consumption basket. For Botswana, the weight amounts to 70.8 percent of total household expenditure. As specified by the law of one price of tradables, the price level of tradables is determined by the world price in foreign currency terms $\left(C P I^{*}\right)$ and the exchange rate $(E R)$, defined in units of foreign currency per one unit of domestic currency: ${ }^{19}$

$$
\ln C P I^{T}=\ln C P I^{*}-\ln E R .
$$

9. The price level of nontradables is supposed to be determined by disequilibrium between the money supply and the demand in the domestic money market. The money supply $\left(M^{s}\right)$ (which is, in principle, a policy variable), and an increase in $M^{s}$ would inflate domestic prices. On the other hand, the increased demand for money $\left(M^{d}\right)$ mitigates inflationary pressures, and is assumed to be a function of real GDP growth $(R G D P)$ and the nominal interest rate (INTR). While higher interest rates make holding money more costly and reduce money demand, real economic expansion increases the transaction demand for money, leading to disinflation. ${ }^{20}$ Thus, inflation of nontradables can be written as:

$$
\ln C P I^{N}=\phi\left(M^{S}, M^{d}(R G D P, I N T R)\right) .
$$

10. We estimate the following reduced-form equation for inflation, derived from equations (1) to (3):

$$
\begin{gathered}
C P I=f\left(C P I^{*}, E R, M^{S}, M^{d}(R G D P, I N T R)\right) \\
+\quad-\quad+
\end{gathered}
$$

Following earlier studies (e.g., Johansen, 1995), the above relationship is specified by a vector error-correction (VEC) model with two lags: ${ }^{21}$

\footnotetext{
${ }^{19}$ For the empirical analysis that follows, all types of exchange rates are defined in foreign-currency terms, meaning that an increase in the exchange rate indicates appreciation.

${ }^{20}$ This assumption, which may simplify the economy too much, ignores the importance of the gap between demand and supply for real goods and services in determining inflation; but it does make the model much more tractable, given the limited sample data.

${ }^{21}$ The number of lags varies from model to model. In most current analysis, the models with two lags have been found to be the most reasonable, though some models have one or three lags.
} 


$$
\begin{aligned}
& \Delta \ln C P I_{t}=\beta_{0}+\sum_{k} \beta_{1 k} \Delta \ln C P I_{t-k}+\sum_{k} \beta_{2 k} \Delta \ln M_{t-k}^{S}+\sum_{k} \beta_{3 k} \Delta \ln E R_{t-k} \\
& +\sum_{k} \beta_{4 k} \Delta \ln R G D P_{t-k}+\sum_{k} \beta_{5 k} \Delta I N T R_{t-k}+\sum_{k} \beta_{6 k} \Delta \ln C P I^{*}{ }_{t-k}+\beta_{7} E C M \ln C P I_{t-1}+\varepsilon_{t}
\end{aligned},
$$

where $\Delta \ln$ is the first difference in logs of the variables, and $E C M \ln C P I_{t}$ is an error correction term associated with disequilibrium from the long-term equilibrium in the money market:

$$
\begin{aligned}
& E C M \ln C P I_{t}=\alpha_{1} \ln C P I_{t}-\alpha_{2} \ln M_{t}^{S}-\alpha_{3} \ln E R_{t}-\alpha_{4} \ln R G D P_{t} \\
& -\alpha_{5} \ln I N T R_{t}-\alpha_{6} \ln C P I_{t}^{*}
\end{aligned}
$$

\section{Data}

11. The analysis uses quarterly data for the period 1993-2005. Before this period, Botswana's high inflation makes it difficult to maintain the common structure assumption of price behavior. The sample period includes the latest quarter for which applicable data are available. The baseline model includes the following seven variables in the system: general consumer prices (CPI), broad money (M2), the exchange rates against the rand (Rand/Pula) and the U.S. dollar (US\$/Pula), quarterly real GDP $(R G D P)$, the 88-day notice deposit rate (Term deposit rate), and South Africa's price level (CPI of SA).

12. These variables were selected over other specifications on the basis of statistical reliability and theoretical consistency (see ANNEX III.II for details). Notably, money supply, which is represented by M2 (currency in circulation plus current and time deposits), while partly interest bearing, does not include Bank of Botswana Certificates (BoBCs). The two foreign exchange variables - the rand per pula and the U.S. dollar per pula - were selected because these two foreign currencies play such an important role in domestic trade patterns. Although a large share of Botswana's imports come from South Africa, ${ }^{22}$ some of them (e.g., oil) are denominated in U.S. dollars. Exports prices do not directly affect the CPI basket, but the international trade prices of diamonds denominated in U.S. dollars, of which Botswana is the world's largest producer, may possibly influence the economy to the large extent.

13. For a proxy variable referred to as the level of world prices, we use the consumer price index of South Africa, given that half of all goods and materials traded in Botswana are imported, with three-quarters of them coming from South Africa. For GDP data, we use the

\footnotetext{
${ }^{22}$ Botswana imported 85.1 percent of total imports from Southern African Customs Union (SACU) members, mainly South Africa, in 2005.
} 
three-period moving average of quarterly GDP. ${ }^{23}$ The average deposit interest rate - though viewed as problematic owing to current negative real interest rates - is the only interest rate variable that has enough time series data and variation over time.

\section{Estimation Results}

\section{Unrestricted model}

14. The augmented Dickey-Fuller unit root tests indicate that almost all variables are nonstationary in levels but stationary in their first differences (Table III.3). ${ }^{24}$ The data also suggest that the trace test statistic can reject the null hypothesis of no cointegration in favor of one cointegrating vector at the 5 percent significance level (Table III.4). ${ }^{25}$

Table III.3. Unit Root Tests

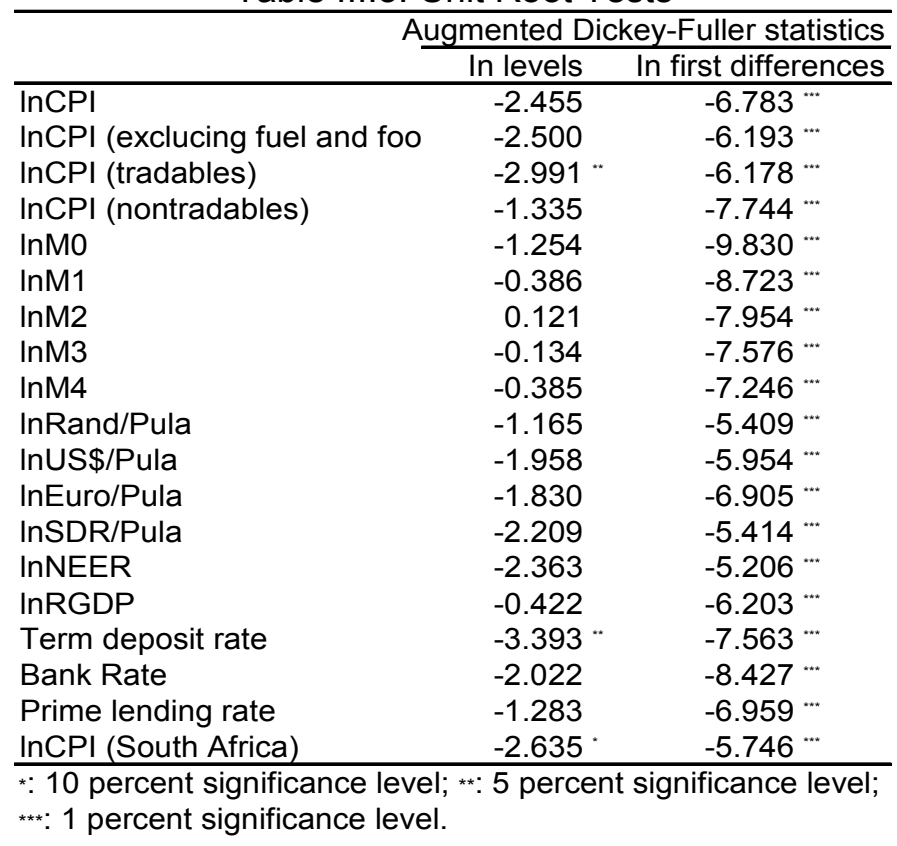

\footnotetext{
${ }^{23}$ This technique smooths data but does not make the data more accurate.

24 Table III.3 includes not only the variables used in the baseline estimation but also the alternative definitions discussed in Annex III.II.

${ }^{25}$ For the trace test, see Johansen (1998).
} 
Table III.4. Cointegration Tests

\begin{tabular}{cccr}
\hline Rank Eigenvalue & $\begin{array}{c}\text { Trace } \\
\text { statistics }\end{array}$ & $\begin{array}{c}5 \% \text { critical } \\
\text { value }\end{array}$ \\
\hline 0 & & 128.463 & 124.24 \\
1 & 0.6511 & $82.133{ }^{* *}$ & 94.15 \\
2 & 0.4919 & 52.341 & 68.52 \\
3 & 0.3271 & 34.908 & 47.21 \\
\hline$* *$ p percent significance level.
\end{tabular}

15. Given the above, the cointegrating equation is estimated as follows:

$$
\begin{aligned}
& \ln C P I=0.142 \ln M 2-0.356 \ln \text { Rand } / \text { Pula }+0.029 \ln U S \$ / \text { Pula } \\
& (0.063) \quad(0.072) \quad(0.040) \\
& -0.476 \ln R G D P+0.035 \text { TermDepositRate }+1.562 \ln \text { CPIofSA }+0.246
\end{aligned}
$$

The estimated dynamic error-correction inflation equation is presented in ANNEX III.I. Note that the cointegrating vector, which makes a set of variables in the system stationary by a suitable choice of its initial distribution, can be interpreted as a long-term equilibrium relationship among monetary aggregates, the exchange rate, real GDP, interest rate, and the price level. All but one sign, that for the exchange rate against the U.S. dollar, are as expected in theory and statistically significant. ${ }^{26}$ The overall fit of the equation is satisfactory. ${ }^{27}$ According to the conventional $\chi^{2}$ test, the hypothesis of all the coefficients being zero can easily be rejected. The test statistics is significantly large at 6129.7 (see Table III.7).

16. The null hypothesis of no autocorrelation in the residual (of Equation (5)) cannot be rejected at the conventional significance level. The Lagrange-multiplier (LM) test statistic is estimated at 50.62, for which the $p$-value is 0.409 . In terms of stability, the largest modulus of other potential cointegrating vectors is at 0.5873 , meaning no modulus is close to the unit root, thus indicating that the estimated cointegrating equation is stable. Finally, the normality test based on the skewness statistics cannot reject the null of normality at the conventional 5 percent significance level, though it can be rejected at the 10 percent significance level.

\footnotetext{
${ }^{26}$ The restriction that the coefficient of the US\$-pula exchange rate is zero produced similar estimation results but did not improve the overall fit of the equation and the normality assumption statistics. See the first and sixth columns in Table III.8.

${ }^{27}$ These events may raise a concern about possible structural changes in the behavior of inflation over the sample period. However, inclusion of the time indicator variables for these periods did not generate more reliable estimation results than the baseline model, which is presented in the following sections.
} 
This finding, though somewhat weak, confirms that the disturbance for the inflation equation is normally distributed.

\section{Restricted model}

17. Imposing some linear restrictions can generate a more concise result. Equations (5) and (6) have the following two restrictions:

$$
\begin{array}{ll}
\beta_{2 k}=-\beta_{4 k} \text { and } \alpha_{2}=-\alpha_{4} & \text { for } \forall k \\
\beta_{6 k}=-\beta_{3 k} \text { and } \alpha_{6}=-\alpha_{3} & \text { for } \forall k
\end{array}
$$

Empirically, equation (7) may not support these restrictions, because the hypothesis for these linear restrictions can be rejected by the standard Wald tests; however, they have a theoretical basis; equation (8) holds under the quantity theory of money with stability of money velocity, and equation (9) implies that imported tradables prices are exactly calculated by the world price and the exchange rate (following equation (2)).

18. With the restrictions, the estimated cointegrating equation is: ${ }^{28}$

$$
\begin{aligned}
\ln C P I= & 0.485(\ln M 2-\ln R G D P)+ \\
(0.064) & 0.067 \text { TermDepositRate } \\
& (0.014) \\
& +0.582(\ln C P \text { IofSA }-\ln \text { Rand } / \text { Pula })+1.515
\end{aligned}
$$

The significance of the coefficients is better than in the unrestricted model. The necessary estimation assumptions are also satisfied, and the dynamic error-correction model is reasonable, though it contains some margins of error, as shown in ANNEX III.I and III.II.

19. Equations (7) and (10) suggest Botswana's prices over the long term behave as follows:

- $\quad$ Both statistically and economically, the strongest determinant of price movements in Botswana is South African inflation. The estimated elasticity of South Africa's inflation relative to Botswana's is 1.6, suggesting that prices between the two countries gets transmitted to a considerable degree. An elasticity well over one surely

\footnotetext{
${ }^{28}$ The exchange rate against the US\$ is omitted in the restricted model. When only one of the restrictions was imposed, the estimation results were found to be unstable.
} 
includes some secondary, indirect effects on domestic tradables and nontradables. ${ }^{29}$ Notably, this result appears consistent with the fact that Botswana's inflation-which averages 9.1 percent over the sample period - has been one-and-a-half times as high as South Africa's average rate- 6.6 percent. By contrast, under the restricted model, the estimated elasticity of inflation imported from South Africa is 0.58, somewhat comparable to the share of imported tradables in the basket (i.e., about 50 percent).

- A depreciation of the pula against South Africa's rand also has a significant inflationary impact (the estimated coefficient is -0.36). In the econometric model, the exchange rate is defined in foreign currency units per pula in logarithm. Similar to South Africa's inflation and interest rate effects, this depreciation effect is relatively powerful in a statistical sense.

- $\quad$ By contrast, the depreciation against the U.S. dollar has a statistically insignificant and economically limited impact on inflation, perhaps because only export prices are denominated in U.S. dollars, making such depreciations less relevant to Botswana's domestic inflation.

- Monetary expansion has a small but significant inflationary impact. At 0.14 , the coefficient indicates a statistically significant but weak relationship between monetary aggregates and prices in the unrestricted equation; by contrast, the change in the ratio of money to GDP exerted a stronger effect in the restricted model, though it was still below that of the South African CPI, adjusted for changes in the rand-pula exchange rate.

- $\quad$ As expected, inflation decreases with real money demand arising from economic expansion: 1 percent GDP growth would cause a half percent of disinflation in equilibrium.

- $\quad$ Finally, higher price levels are associated with higher interest rates. The equation shows that a 1 percent increase in (term deposit) interest rates is accompanied by a 3.5 percent of inflation. ${ }^{30,31}$

\footnotetext{
${ }^{29}$ Even if inflation is measured for only nontradables, South Africa's price level has a significant and large impact (Table III.7), suggesting there is a significant degree of price transmission from tradables to nontradables. In addition, domestic inflation expectations might be highly sensitive to import inflation from South Africa, accelerating domestic prices. Otherwise, the elasticity would not exceed unity.

${ }^{30}$ Note that interest rates are in percent. The other variables are in logarithm. Therefore, the equation implies that $\frac{\Delta C P I}{C P I}=0.035 \Delta$ TermDepositRate .
} 


\section{E. Conclusion}

20. The analysis explores the long-term behavior of inflation in Botswana. Not surprisingly, changes in South Africa's consumer prices largely determine inflation. Changes in the exchange rate against the South African rand also affect inflation. These findings support the view that Botswana, as a typical small open economy, is closely linked to a large neighboring economy. This linkage means Botswana's monetary and exchange policies must consider the external economic environment, particularly the pula's exchange rate against the rand. The inflation objective must also be consistent with South Africa's monetary stance.

21. The empirical result also sheds light on the need for prudent monetary policy to keep inflation low. The estimated effect of monetary expansion on inflation looks very small and only marginally different from zero. Nonetheless, it is statistically significant, thus indicating that money growth is modestly inflationary. M2 is the only monetary aggregate variable that produced an estimation result consistent with theory; the estimation using other aggregates implied a negative association between money growth and inflation.

22. In addition to money supply, the interest rate adjustment seems effective in monetary policy transmission to a certain, but not large, extent. The evidence suggests that, in equilibrium, 1 percent of inflation would require 0.3 percent higher (term deposit) interest rates.

\footnotetext{
${ }^{31}$ The cointegrating equation merely shows the long-run relations between the variables in the economy, toward which the agents try to force the variables back. There is no causality. Thus, the coefficient of 0.035 means that if inflation goes up by 1 percent, the interest rate should rise by about 0.3 percent.
} 


\section{ANNEX III.I: Estimated Error-Correction Inflation Equation}

23. The error-correction inflation equations associated with the cointegrating equations (7) and (10) are presented in Table III.5. The short-term movements in domestic real GDP and consumer prices in South Africa have significant coefficients in the unrestricted model. Inflation decelerates with real growth and tends to be stimulated by South African inflation. Exchange rate depreciations against the rand also appear to fuel inflation, though the effect is statistically ambiguous. However, the restricted model indicates that the import inflation through the pula-rand exchange rate has a significant effect. The impact of monetary supply and interest rates are also subject to a wide margin of error, a result that may reflect the limited number of sample observations as well as the relatively strong ability of the cointegrating vector to capture the relationship among the endogenous variables.

24. To complement the above estimations, Granger causality tests were performed based on the system of seven error-correction equations (Table III.6). In the unrestricted model, South Africa's inflation Granger-causes inflation in Botswana, and vice versa,${ }^{32}$ revealing that the two countries' price developments are interdependent. It is also finds that, while real growth Granger-causes disinflation, monetary supply does not cause inflation in the short run. The Granger-causality between inflation and exchange rate depreciation remains inconclusive, though the evidence supports the view that Botswanan inflation causes the pula to depreciate against the rand (the $p$-value is 0.197 ).

25. The impulse response function depicts the effect of one-standard error originating from a variable in the system on other endogenous variables thorough the dynamic structure (Figures III.5 and III.6). Despite the difficulty of assessing the results, owing to generally large standard errors (particularly in the unrestricted model), a positive inflation shock in South Africa would likely raise Botswana's inflation rate for about 12 quarters (three years). A real shock would likely result in some disinflation. Although the impact of monetary and exchange rate shocks are difficult to assess because of their unstable transition paths, the projected response indicates that monetary shocks have a limited short-term impact on prices.

\footnotetext{
${ }^{32}$ The restricted model suggests that the causality between South Africa's and Botswana's inflation may be insignificant.
} 
Table III.5. Error-Correction Inflation Equation ${ }^{1}$

\begin{tabular}{|c|c|c|}
\hline \multirow{2}{*}{$\overline{E C M \ln C P I(-1)}$} & Unrestricted & Restricted \\
\hline & $\begin{array}{r}-0.063 \\
(0.057)\end{array}$ & $\begin{array}{c}-0.065 \\
(0.030)\end{array}$ \\
\hline$\Delta \operatorname{lnCPI}(-1)$ & $\begin{array}{r}-0.021 \\
(0.156)\end{array}$ & $\begin{array}{r}-0.114 \\
(0.148)\end{array}$ \\
\hline$\Delta \mathrm{lnM} 2(-1)$ & $\begin{array}{r}-0.007 \\
(0.033)\end{array}$ & \\
\hline$\Delta(\operatorname{lnM} 2-\ln R G D P)(-1)$ & & $\begin{array}{r}-0.016 \\
(0.031)\end{array}$ \\
\hline$\Delta$ InRand/pula(-1) & $\begin{array}{r}-0.031 \\
(0.059)\end{array}$ & \\
\hline$\Delta \operatorname{lnUS} \$ / p u l a(-1)$ & $\begin{array}{r}0.019 \\
(0.035)\end{array}$ & \\
\hline$\Delta \operatorname{lnRGDP}(-1)$ & $\begin{array}{l}-0.134 \\
(0.066)\end{array}$ & \\
\hline$\Delta$ Term Deposit Rate(-1) & $\begin{array}{r}-0.001 \\
(0.002)\end{array}$ & $\begin{array}{l}-0.003 \\
(0.002)\end{array}$ \\
\hline$\Delta \operatorname{lnCPI}$ of $\mathrm{SA}(-1)$ & $\begin{array}{c}0.236 \\
(0.127)\end{array}$ & \\
\hline$\Delta(\operatorname{InCPI}$ of $\mathrm{SA}-\mathrm{InRand} / \mathrm{pula})(-1)$ & & $\begin{array}{c}0.092 \\
(0.042)\end{array}$ \\
\hline Constant & $\begin{array}{r}0.018 \\
(0.004)\end{array}$ & $\begin{array}{c}0.020 \\
(0.003)\end{array}$ \\
\hline $\begin{array}{l}\text { Obs. } \\
\text { R-squared }\end{array}$ & $\begin{array}{r}44 \\
08772\end{array}$ & $\begin{array}{r}44 \\
08615\end{array}$ \\
\hline
\end{tabular}

${ }_{1 *} 10$ percent significance level; ** 5 percent significance level;

*** 1 percent significance level.

Table III.6. Granger Causality ${ }^{1}$

\begin{tabular}{|c|c|c|c|}
\hline & & Chi2 st & stics $^{2}$ \\
\hline & & Unrestricted & Restricted \\
\hline InM2 & $\rightarrow \operatorname{lnCPI}$ & 0.065 & \\
\hline InCPI & $\rightarrow \operatorname{lnM} 2$ & 0.124 & \\
\hline InM2-InGDP & $->\operatorname{InCPI}$ & & 0.313 \\
\hline InCPI & $\rightarrow \operatorname{lnM} 2-\ln G D P$ & & 2.048 \\
\hline InRand/pula & $->\operatorname{lnCPI}$ & 0.361 & \\
\hline $\operatorname{lnCPI}$ & $\rightarrow$ InRand/pula & 1.664 & \\
\hline InUS\$/pula & $\rightarrow \operatorname{InCPI}$ & 0.374 & \\
\hline InCPI & $\rightarrow$ InUS\$/pula & 0.062 & \\
\hline InRGDP & $->\operatorname{InCPI}$ & $5.143^{*}$ & \\
\hline InCPI & -> InRGDP & 1.790 & \\
\hline Term Deposit Rate & $->\operatorname{lnCPI}$ & 0.585 & 2.550 \\
\hline InCPI & -> Term Deposit Rate & 0.113 & 0.034 \\
\hline InCPI of SA & $\rightarrow \operatorname{lnCPI}$ & $4.315^{*}$ & \\
\hline InCPI & $\rightarrow \operatorname{lnCPI}$ of $\mathrm{SA}$ & $2.766^{*}$ & \\
\hline InCPI of SA-InRand/pula & $\rightarrow \operatorname{lnCPI}$ & & $5.660 *$ \\
\hline InCPI & -> InCPI of SA-InRand/pul & & 2.450 \\
\hline
\end{tabular}

$1 * 10$ percent significance level; ** 5 percent significance level.

${ }^{2}$ The degree of freedom is all equal to one. 
Figure III.6. Impulse Response Function, Unrestricted Model
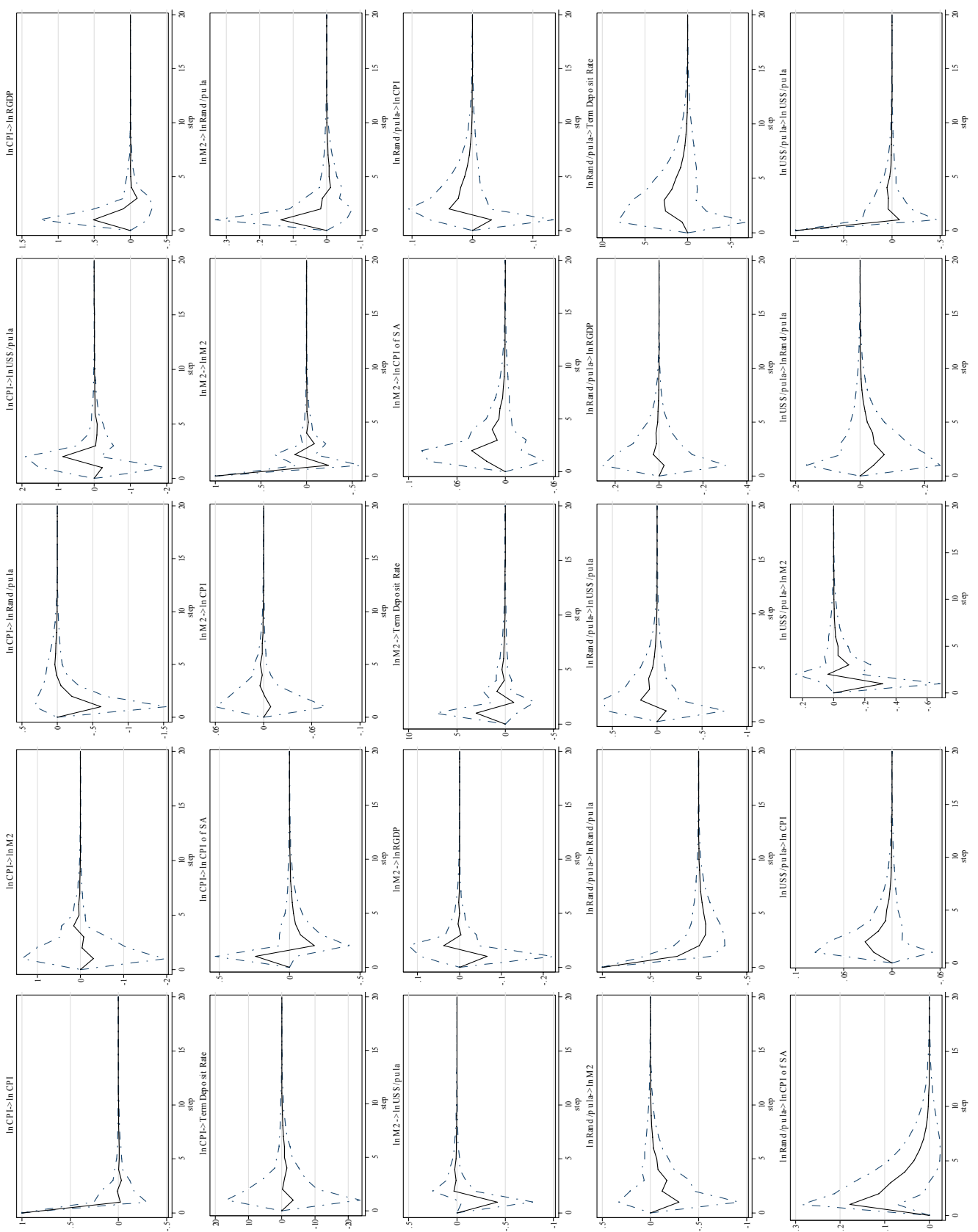
Figure III.6. Impulse Response Function, Unrestricted Model (Contd.)
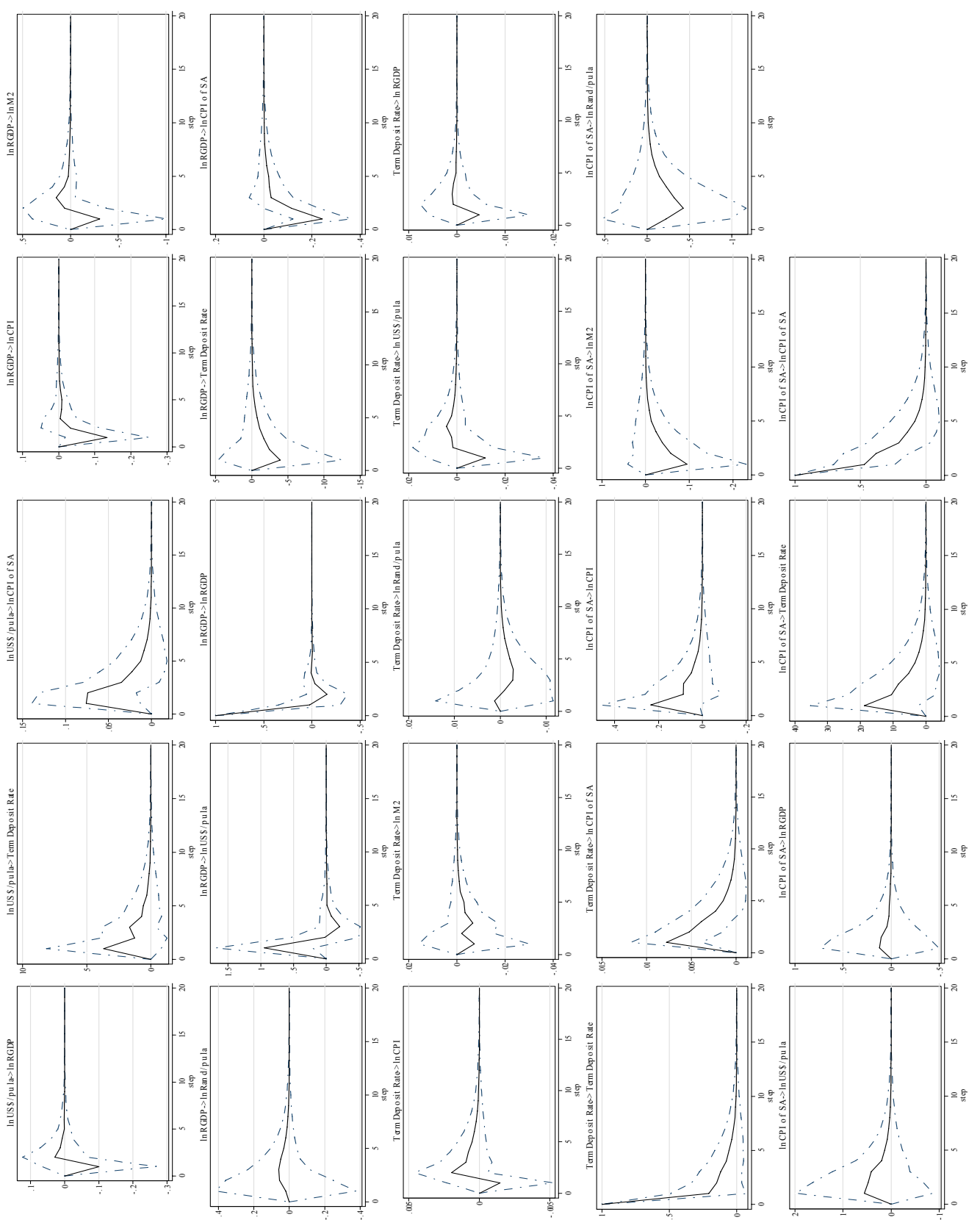
Figure III.7. Impulse Response Function, Restricted Model
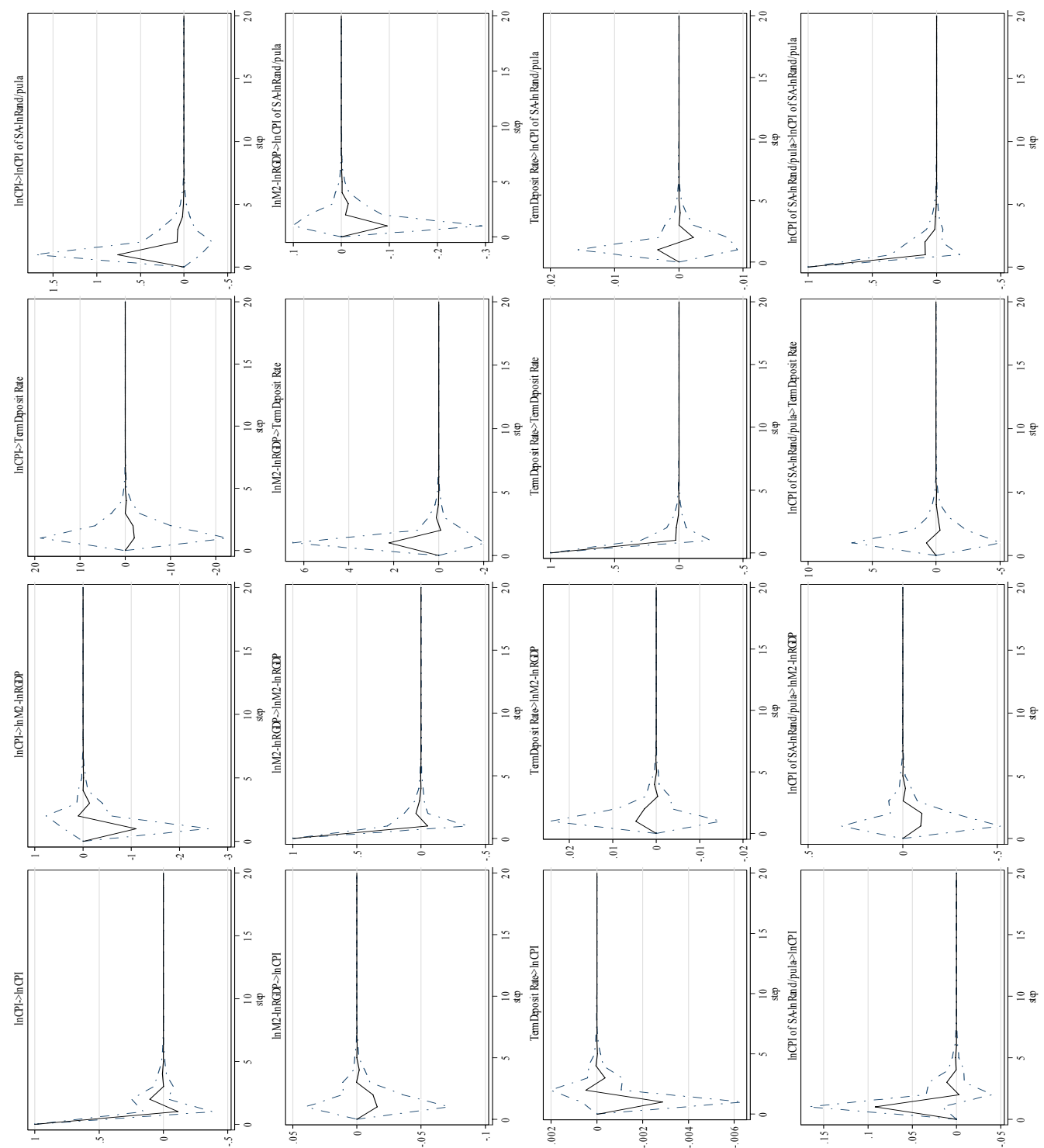


\section{ANNEX III.II: Alternative Specifications for Cointegrating Equations}

26. This Annex examines the selection of the variables used for the baseline estimation. Compared with other estimation results using different variables, the baseline model is the most significant in a statistical sense and the most consistent with economic theory. The analytical framework is the same as in the main text; the choice of the number of cointegrating equations follows the Johansen's trace test technique, and the stationarity of almost all variables is confirmed in Table III.3.

27. First, in the baseline model, the price level is measured by a general consumer price index $(C P I)$. An alternative measurement may be the price level, excluding exogenous factors, such as food and energy prices. The second column in Table III.7 shows the estimated cointegrating equation for CPI, excluding fuel and food items. ${ }^{33}$ The result looks similar to the baseline model's, but the overall fit is less favorable, though the disturbance meets the normality assumption more favorably. Meanwhile, when taking CPI for only tradables or nontradables, the estimated equations hardly satisfy the normality assumption. Notably, however, the coefficients between these two models are close, suggesting that tradable prices affect nontradables prices, and vice versa.

28. Second, the baseline model defines money supply as a broader measurement, $M 2$, which is defined as currency in circulation plus current and time deposits. This measure covers interest-bearing accounts but does not include the Bank of Botswana Certificates (BoBCs), which are one of Botswana's major saving instruments. ${ }^{34}$ With narrower monetary aggregates $(M 0$ or $M 1)$ included in the model, the impact of monetary expansion turned negative (Table IV.8), a result that defies theory. On the other hand, with broader monetary aggregates (M3 or M4), the coefficients of money supply are also negative and insignificant; however, this finding may be reasonable because the BoBCs, which are part of $M 3$ and $M 4$, are used to mop up excess liquidity and contain the inflationary impact of monetary growth. Nonetheless, all these alternative models violate the normality assumption.

\footnotetext{
${ }^{33}$ Botswana depends on imports for all petroleum products. The domestic retail petroleum prices are periodically reviewed by a joint committee comprising government and private oil companies, based on a predetermined formula that basically aims to pass-through international oil prices with a medium-term price stabilization mechanism (i.e., the National Petrol Fund).

${ }^{34}$ The outstanding amount of BoBCs, excluding those held by banks on their own accounts, reached 8 billion pula, or about 15 percent of GDP at year-end 2005, owing to relatively attractive interest rates. The Bank of Botswana has used the BoBCs to mop up excess liquidity. Given the emerging inflationary pressures in these years, the (period average) share of BoBCs in M3, which is M2 plus BoBCs held by nonbanks, has increased from 25 percent in 1998-2001 to 35 percent in 2002-05.
} 
29. For the exchange rate, the baseline adopted two bilateral exchange rates against the South Africa's rand (Rand/Pula) and the U.S. dollar (US\$/Pula). While Botswana imports most goods from a neighboring country, South Africa, the U.S. dollar figures prominently in the international trade markets, including diamonds. An obvious alternative is the euro (Euro/Pula) or the SDR (SDR/Pula), but the real growth and monetary growth results were theoretically inconsistent, and a stability concern remained. The estimation using the rand and SDR, both of which make up Botswana's currency basket, is close to the baseline model's, though money does not have a significant coefficient. The nominal effective exchange rate $(N E E R)$ is another way to incorporate all relevant foreign exchange rates in the model. The VEC estimation with the NEER index, which is employed from the standard IMF Effective Exchange Rate Facility database, generates a cointegrating vector that differs dramatically from that of the other specifications and is inconsistent with theory (the 11th column).

30. Finally, there are two interest rate data other than the 88-day notice deposit rate: the Bank Rate and primary lending rate, both of which are closely related to each other. The estimated cointegrating equation with the Bank Rate is more or less similar to the baseline, though the coefficients of real GDP and money supply are insignificant (though they have correct sign). ${ }^{35}$ Notably, the model indicates that 1 percent of inflation would be associated with higher interest rate increases than in the baseline estimation. This finding makes sense because the Bank Rate has varied little over the past decade, and thus tends to be used to respond relatively actively to any given price movement. ${ }^{36}$ However, this inelasticity calls into question the empirical validity of the unit-root technique used in the analysis.

\footnotetext{
${ }^{35}$ In case there are multiple cointegrating vectors, the basic solution would be to interpret them, taking into account structural restrictions based on the original economic models (Johansen and Juselius, 1992).

${ }^{36}$ The standard deviation was 1.27 for the 88 -day notice deposit rate for the sample period, 0.87 for the Bank Rate, and 0.90 for the primary lending rate.
} 
Table III.7. Alternative Cointegrating Equations for Different CPIs ${ }^{1}$

\begin{tabular}{|c|c|c|c|c|c|c|c|}
\hline Dependent variable & $\begin{array}{c}\text { InCPI } \\
\text { [baseline/ } \\
\text { unrestricted] }\end{array}$ & $\begin{array}{c}\text { InCPI } \\
\text { [baseline/ } \\
\text { restricted] }\end{array}$ & $\begin{array}{c}\text { InCPI } \\
\text { (ex. } \\
\text { fuel/food) }\end{array}$ & $\begin{array}{c}\text { InCPI } \\
\text { (tradables) }\end{array}$ & $\begin{array}{c}\operatorname{lnCPI} \\
\text { (tradables) }\end{array}$ & $\begin{array}{c}\operatorname{lnCPI} \\
\text { (non- } \\
\text { tradables) }\end{array}$ & $\begin{array}{c}\text { InCPI } \\
\text { (non- } \\
\text { tradables) }\end{array}$ \\
\hline $\ln \mathrm{M} 2$ & $\begin{array}{c}0.141 \\
(0.063)\end{array}$ & & $\begin{array}{c}0.160 \text { * } \\
(0.078)\end{array}$ & $\begin{array}{c}0.152 \\
(0.060)\end{array}$ & & $\begin{array}{c}0.169{ }^{*} \\
(0.086)\end{array}$ & $\begin{array}{l}-0.336 \\
(0.169)\end{array}$ \\
\hline InM2-InRGDP & & $\begin{array}{c}0.485 \\
(0.064)\end{array}$ & & & & & \\
\hline InRand/Pula & $\begin{array}{l}-0.356 \\
(0.072)\end{array}$ & & $\begin{array}{l}-0.412 \\
(0.087)\end{array}$ & $\begin{array}{l}-0.375 \\
(0.069)\end{array}$ & $\begin{array}{l}-0.375 \\
(0.173)\end{array}$ & $\begin{array}{l}-0.347^{* *} \\
(0.098)\end{array}$ & \\
\hline InUS\$/Pula & $\begin{array}{r}0.029 \\
(0.040)\end{array}$ & & $\begin{array}{r}0.037 \\
(0.048)\end{array}$ & $\begin{array}{r}-0.018 \\
(0.038)\end{array}$ & $\begin{array}{c}0.530 \\
(0.101)\end{array}$ & $\begin{array}{c}0.177 \\
(0.055)\end{array}$ & \\
\hline InRGDP & $\begin{array}{c}-0.476 \\
(0.179)\end{array}$ & & $\begin{array}{c}-0.387^{*} \\
(0.212)\end{array}$ & $\begin{array}{l}-0.634 \\
(0.175)\end{array}$ & & $\begin{array}{c}-0.431^{\circ} \\
(0.238)\end{array}$ & $\begin{array}{c}1.951 \\
(0.411)\end{array}$ \\
\hline Time deposit rate & $\begin{array}{r}0.035 \\
(0.005)\end{array}$ & $\begin{array}{l}0.0677^{* * *} \\
(0.014)\end{array}$ & $\begin{array}{c}0.048 \\
(0.006)\end{array}$ & $\begin{array}{c}0.029 \\
(0.005)\end{array}$ & & $\begin{array}{c}0.056 \\
(0.007)\end{array}$ & $\begin{array}{c}0.081 \\
(0.014)\end{array}$ \\
\hline $\operatorname{InCPI}$ of $\mathrm{SA}$ & $\begin{array}{c}1.562 \\
(0.129)\end{array}$ & & $\begin{array}{c}1.478 \\
(0.159)\end{array}$ & $\begin{array}{c}1.619 \\
(0.127)\end{array}$ & $\begin{array}{l}2.067 \\
(0.132)\end{array}$ & $\begin{array}{c}1.685 \\
(0.177)\end{array}$ & \\
\hline \multicolumn{2}{|c|}{ InCPI of SA-InRand/Pula } & $\begin{array}{c}0.582 \\
(0.141)\end{array}$ & & & & & \\
\hline Constant & 0.246 & 1.515 & -0.680 & 1.216 & -3.709 & -0.920 & -9.228 \\
\hline Obs. & 44 & 44 & 44 & 44 & 50 & 44 & 45 \\
\hline Lags & 2 & 2 & 2 & 2 & 2 & 2 & 1 \\
\hline Chi2 statistics & 6129.7 & 585.1 & 4409.0 & 6098.9 & 771.4 & 3655.3 & 464.1 \\
\hline \multicolumn{8}{|l|}{ No autocorrelation: } \\
\hline LM test statistics & 50.62 & 15.20 & 52.29 & 39.92 & 14.04 & 60.18 & 24.66 \\
\hline p-value & 0.409 & 0.510 & 0.347 & 0.819 & 0.596 & 0.132 & 0.076 \\
\hline \multicolumn{8}{|l|}{ Skewness test: } \\
\hline Chi2 statistics & 3.23 & 1.96 & 0.19 & 4.53 & 6.08 & 7.22 & 8.50 \\
\hline$p$-value & 0.072 & 0.162 & 0.664 & 0.033 & 0.014 & 0.007 & 0.004 \\
\hline
\end{tabular}

${ }^{*} 10$ percent significance level; ${ }^{* *} 5$ percent significance level; ${ }^{* * *} 1$ percent significance level. 


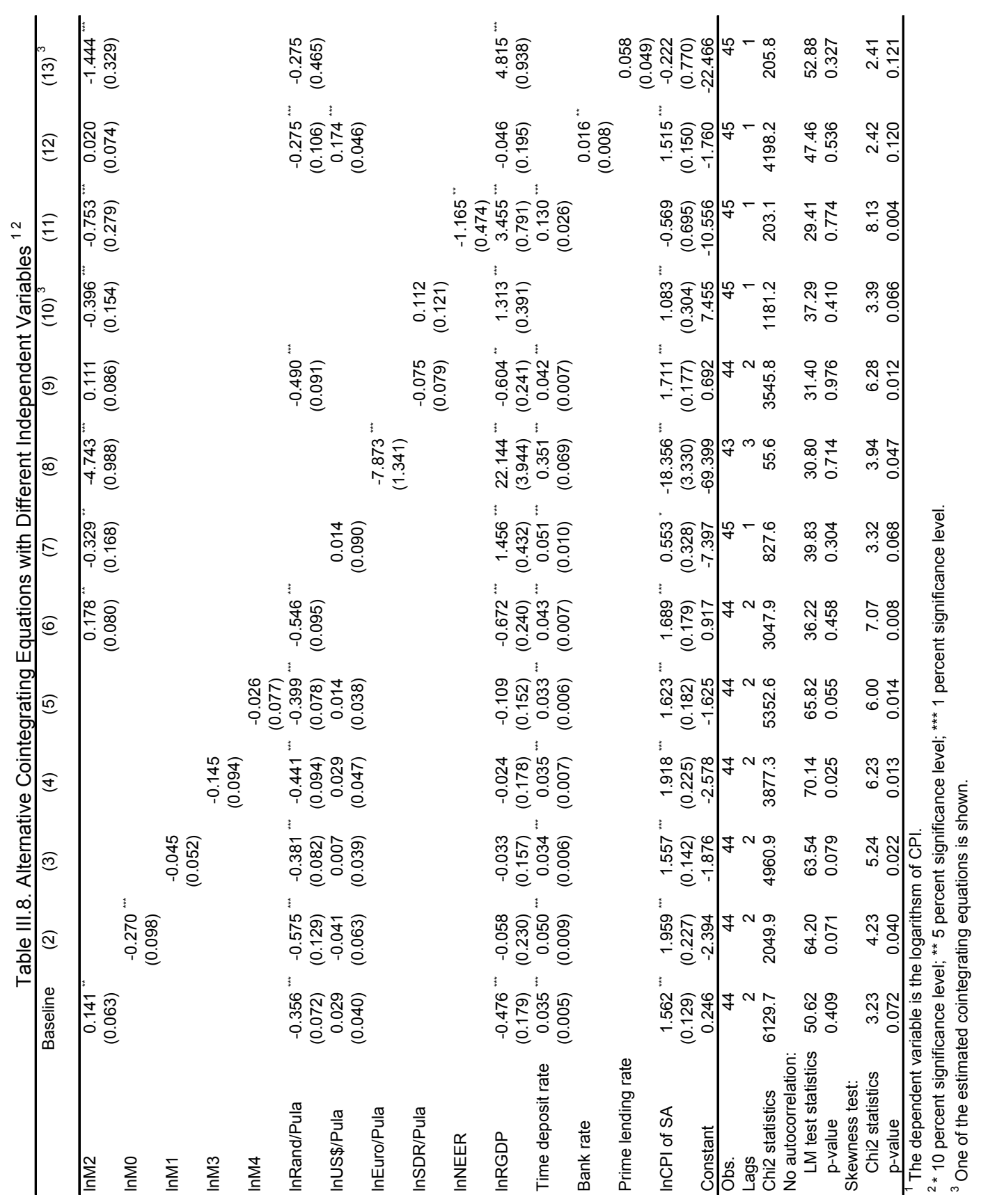




\section{References}

Gasha, J., 2003, “A Note on Inflation," in Angola - Selected Issues and Statistical Appendix, IMF Staff Country Report No. 03/292, by G. Pastor et al. (Washington: International Monetary Fund).

Johansen, S., 1988, Statistical Analysis of Cointegration Vectors, Journal of Economic Dynamics and Control 12, pp. 231-54.

— 1995, Likelihood-Based Inference in Cointegrated Vector Autoregressive Models (New York: Oxford University Press).

Johansen, S., and K. Juselius, 1992, Testing Structural Hypotheses in a Multivariate Cointegration analysis of the PPP and the UIP for UK, Journal of Econometrics 53, pp. 21144.

Kuijs, A., 2000, "Monetary Policy, the Exchange Rate and Inflation," in São Tomé and Príncipe - Recent Economic Developments and Selected Issues, IMF Staff Country Report No. 00/69, by I. Thiam et al. (Washington: International Monetary Fund).

Muñoz, S., 2005, "High Inflation and Money Demand," in Zimbabwe - Selected Issues and Statistical Appendix, IMF Staff Country Report No. 05/359, by S. Coorey et al. (Washington: International Monetary Fund).

Nassar, K., 2005, "Determinants of Inflation in Madagascar," in Republic of Madagascar Selected Issues and Statistical Appendix, IMF Staff Country Report No. 05/321, by A. Fayolle et al. (Washington: International Monetary Fund).

Williams, O., and O. Adedeji, 2004, "Inflation Dynamics in the Dominican Republic," IMF Working Paper No. 04/29 (Washington: International Monetary Fund). 
Table 1. Botswana: GDP by Type of Expenditure at Current Prices, 2000/01-2004/05 1/

\begin{tabular}{|c|c|c|c|c|c|}
\hline & $2000 / 01$ & $2001 / 02$ & $2002 / 03$ & $\begin{array}{r}2003 / 04 \\
\text { Rev. } \\
\end{array}$ & $\begin{array}{r}2004 / 05 \\
\text { Rev. }\end{array}$ \\
\hline & \multicolumn{5}{|c|}{ (In millions of pula) } \\
\hline Total consumption & 14,956 & 16,656 & 19,303 & 21,188 & 24,633 \\
\hline General government & 6,518 & 7,348 & 8,967 & 9,162 & 11,104 \\
\hline Central government & 5,759 & 6,462 & 7,921 & 8,045 & 9,890 \\
\hline Local government & 759 & 886 & 1,047 & 1,117 & 1,214 \\
\hline Private & 8,439 & 9,308 & 10,336 & 12,027 & 13,529 \\
\hline Total investment & 13,710 & 14,798 & 15,457 & 18,401 & 16,958 \\
\hline Gross fixed capital formation & 6,898 & 7,743 & 8,736 & 9,018 & 9,937 \\
\hline Public & 3,372 & 3,824 & 4,150 & 4,170 & 3,895 \\
\hline Private & 3,526 & 3,920 & 4,586 & 4,848 & 6,042 \\
\hline Changes in stocks & 6,812 & 7,055 & 6,721 & 9,383 & 7,021 \\
\hline Net exports of goods and services & 7,021 & 4,355 & 4,273 & 3,251 & 7,162 \\
\hline Exports of goods and services & 17,826 & 16,399 & 19,182 & 17,875 & 24,266 \\
\hline Of which: exports of goods & 15,983 & 13,844 & 15,797 & 14,182 & 19,557 \\
\hline Imports of goods and services & $-10,806$ & $-12,044$ & $-14,909$ & $-14,624$ & $-17,105$ \\
\hline Of which: imports of goods & $-8,965$ & $-10,038$ & $-12,780$ & $-12,112$ & $-14,225$ \\
\hline Gross domestic savings 2/ & 19,831 & 19,038 & 20,175 & 21,392 & 24,120 \\
\hline Central government & 3,742 & 6,025 & 5,446 & 7,031 & 7,085 \\
\hline Other & 12,335 & 12,945 & 14,631 & 16,411 & 18,665 \\
\hline Resource gap & 6,121 & 4,240 & 4,718 & 2,991 & 7,162 \\
\hline \multirow[t]{2}{*}{ Total GDP } & 34,787 & 35,693 & 39,478 & 42,580 & 48,753 \\
\hline & \multicolumn{5}{|c|}{ (In percent of GDP) } \\
\hline Total consumption & 43.0 & 46.7 & 48.9 & 49.8 & 50.5 \\
\hline General government & 18.7 & 20.6 & 22.7 & 21.5 & 22.8 \\
\hline Central government & 16.6 & 18.1 & 20.1 & 18.9 & 20.3 \\
\hline Local government & 2.2 & 2.5 & 2.7 & 2.6 & 2.5 \\
\hline Private & 24.3 & 26.1 & 26.2 & 28.2 & 27.8 \\
\hline Total investment & 39.4 & 41.5 & 39.2 & 43.2 & 34.8 \\
\hline Gross fixed capital formation & 19.8 & 21.7 & 22.1 & 21.2 & 20.4 \\
\hline Public & 9.7 & 10.7 & 10.5 & 9.8 & 8.0 \\
\hline Private & 10.1 & 11.0 & 11.6 & 11.4 & 12.4 \\
\hline Changes in stocks & 19.6 & 19.8 & 17.0 & 22.0 & 14.4 \\
\hline Net exports of goods and services & 20.2 & 12.2 & 10.8 & 7.6 & 14.7 \\
\hline Exports of goods and services & 51.2 & 45.9 & 48.6 & 42.0 & 49.8 \\
\hline Of which: exports of goods & 45.9 & 38.8 & 40.0 & 33.3 & 40.1 \\
\hline Imports of goods and services & -31.1 & -33.7 & -37.8 & -34.3 & -35.1 \\
\hline Of which: imports of goods & -25.8 & -28.1 & -32.4 & -28.4 & -29.2 \\
\hline Gross domestic savings 2/ & 57.0 & 53.3 & 51.1 & 50.2 & 49.5 \\
\hline Central government & 10.8 & 16.9 & 13.8 & 16.5 & 14.5 \\
\hline Other & 35.5 & 36.3 & 37.1 & 38.5 & 38.3 \\
\hline Resource gap & 17.6 & 11.9 & 11.9 & 7.0 & 14.7 \\
\hline
\end{tabular}

Source: Central Statistics Office.

1/ National accounts year beginning July 1 .

2/ GDP minus consumption. 
Table 2. Botswana: GDP by Type of Expenditure at Constant 1993/94 Prices, 2000/01-2004/05 1/

\begin{tabular}{|c|c|c|c|c|c|}
\hline & $2000 / 01$ & $2001 / 02$ & $2002 / 03$ & $\begin{array}{r}2003 / 04 \\
\text { Rev. }\end{array}$ & $\begin{array}{r}2004 / 05 \\
\text { Rev. }\end{array}$ \\
\hline & \multicolumn{5}{|c|}{ (In millions of pula) } \\
\hline Consumption & 9,705 & 10,586 & 10,963 & 9,759 & 10,434 \\
\hline Public & 4,967 & 5,635 & 5,969 & 4,299 & 4,696 \\
\hline Private & 4,738 & 4,951 & 4,994 & 5,461 & 5,738 \\
\hline Total investment & 9,124 & 8,183 & 7,992 & 8,361 & 7,710 \\
\hline Gross fixed capital formation & 4,194 & 4,451 & 4,516 & 4,148 & 4,159 \\
\hline Of which: general government & 7,431 & 6,664 & 6,509 & 6,810 & 6,279 \\
\hline Changes in stocks & 4,930 & 3,732 & 3,476 & 4,212 & 3,551 \\
\hline Net exports of goods and services & 2,880 & 1,434 & 1,135 & 710 & 2,070 \\
\hline Exports of goods and services & 8,967 & 7,871 & 8,408 & 7,371 & 9,316 \\
\hline Imports of goods and services & $-6,087$ & $-6,437$ & $-7,273$ & $-6,661$ & $-7,246$ \\
\hline Gross domestic expenditure & 18,829 & 18,769 & 18,955 & 18,120 & 18,143 \\
\hline \multirow[t]{2}{*}{ GDP at constant prices } & 18,242 & 18,530 & 20,298 & 20,985 & 22,742 \\
\hline & \multicolumn{5}{|c|}{ (Annual percentage change) } \\
\hline Consumption & 4.6 & 9.1 & 3.6 & -11.0 & 6.9 \\
\hline Public & 9.4 & 13.5 & 5.9 & -28.0 & 9.2 \\
\hline Private & -0.1 & 4.5 & 0.9 & 9.3 & 5.1 \\
\hline Total investment & 166.4 & -10.3 & -2.3 & 4.6 & -7.8 \\
\hline Gross fixed capital formation & -6.0 & 6.1 & 1.5 & -8.1 & 0.3 \\
\hline Of which: general government & 218.5 & -10.3 & -2.3 & 4.6 & -7.8 \\
\hline Changes in stocks & -574.9 & -24.3 & -6.8 & 21.2 & -15.7 \\
\hline Net exports of goods and services & 48.0 & -50.2 & -20.9 & -37.4 & 191.5 \\
\hline Exports of goods and services & 7.8 & -12.2 & 6.8 & -12.3 & 26.4 \\
\hline Imports of goods and services & -4.5 & 5.8 & 13.0 & -8.4 & 8.8 \\
\hline Gross domestic expenditure & 48.2 & -0.3 & 1.0 & -4.4 & 0.1 \\
\hline GDP at constant prices & 19.7 & 1.6 & 9.5 & 3.4 & 8.4 \\
\hline
\end{tabular}

Source: Central Statistics Office.

1/ National accounts year beginning July 1 . 
Table 3. Botswana: GDP by Type of Economic Activity at Current Prices, 2000/01-2004/05 1/

\begin{tabular}{|c|c|c|c|c|c|}
\hline & $2000 / 01$ & $2001 / 02$ & $2002 / 03$ & $\begin{array}{r}2003 / 04 \\
\text { Rev. }\end{array}$ & $\begin{array}{r}2004 / 05 \\
\text { Rev. }\end{array}$ \\
\hline & \multicolumn{5}{|c|}{ (In millions of pula) } \\
\hline Agriculture & 755 & 792 & 871 & 952 & 1,034 \\
\hline Mining & 16,236 & 15,013 & 14,704 & 15,079 & 18,527 \\
\hline Manufacturing & 1,344 & 1,404 & 1,550 & 1,648 & 1,752 \\
\hline Water and electricity & 689 & 750 & 927 & 1,059 & 1,169 \\
\hline Construction & 1,563 & 1,738 & 1,976 & 2,103 & 2,242 \\
\hline Trade and hotels & 3,193 & 3,651 & 4,969 & 4,894 & 5,083 \\
\hline Transport & 1,058 & 1,151 & 1,288 & 1,399 & 1,609 \\
\hline Banking, insurance, and business services & 3,202 & 3,644 & 4,096 & 4,525 & 5,123 \\
\hline General government & 4,568 & 5,264 & 5,979 & 7,232 & 8,024 \\
\hline Social and personal services & 1,107 & 1,249 & 1,394 & 1,595 & 1,692 \\
\hline Adjustments items & 1,073 & 1,038 & 1,723 & 2,095 & 2,499 \\
\hline \multirow[t]{2}{*}{ GDP at current prices } & 34,787 & 35,693 & 39,478 & 42,580 & 48,753 \\
\hline & \multicolumn{5}{|c|}{ (In percent of total GDP) } \\
\hline Agriculture & 2.6 & 2.5 & 2.4 & 2.2 & 2.1 \\
\hline Mining & 35.2 & 35.2 & 34.4 & 35.4 & 38.0 \\
\hline Manufacturing & 4.7 & 4.4 & 4.2 & 3.9 & 3.6 \\
\hline Water and electricity & 2.4 & 2.3 & 2.5 & 2.5 & 2.4 \\
\hline Construction & 5.5 & 5.4 & 5.4 & 4.9 & 4.6 \\
\hline Trade and hotels & 11.2 & 11.4 & 11.4 & 11.5 & 10.4 \\
\hline Transport & 3.7 & 3.6 & 3.5 & 3.3 & 3.3 \\
\hline Banking, insurance, and business services & 11.2 & 11.4 & 11.2 & 10.6 & 10.5 \\
\hline General government & 16.0 & 16.5 & 15.8 & 17.0 & 16.5 \\
\hline Social and personal services & 3.9 & 3.9 & 3.8 & 3.7 & 3.5 \\
\hline Adjustments items & 3.7 & 3.3 & 5.4 & 4.9 & 5.1 \\
\hline GDP at current prices & 100.0 & 100.0 & 100.0 & 100.0 & 100.0 \\
\hline
\end{tabular}

Source: Central Statistics Office.

1/ National accounts year beginning July 1 . 
Table 4. Botswana: GDP by Type of Economic Activity at Constant 1993/94 Prices, 2000/01-2004/05 1/

\begin{tabular}{|c|c|c|c|c|c|}
\hline & $2000 / 01$ & $2001 / 02$ & $2002 / 03$ & $\begin{array}{r}2003 / 04 \\
\text { Rev. }\end{array}$ & $\begin{array}{r}2004 / 05 \\
\text { Rev. }\end{array}$ \\
\hline & \multicolumn{5}{|c|}{ (In millions of pula) } \\
\hline Agriculture & 445 & 433 & 441 & 454 & 469 \\
\hline Mining & 7,753 & 7,489 & 8,285 & 8,308 & 9,821 \\
\hline Manufacturing & 681 & 682 & 703 & 709 & 691 \\
\hline Water and electricity & 391 & 406 & 444 & 472 & 488 \\
\hline Construction & 955 & 1,000 & 1,005 & 1,027 & 1,034 \\
\hline Trade and hotels & 1,700 & 1,840 & 1,990 & 2,215 & 2,069 \\
\hline Transport & 605 & 625 & 631 & 610 & 644 \\
\hline Banking, insurance, and business services & 1,795 & 1,922 & 1,973 & 2,020 & 2,102 \\
\hline General government & 2,641 & 2,861 & 3,267 & 3,434 & 3,558 \\
\hline Social and personal services & 663 & 705 & 724 & 775 & 771 \\
\hline Adjustment items & 614 & 567 & 833 & 963 & 1,095 \\
\hline GDP at constant prices & 18,242 & 18,530 & 20,298 & 20,985 & 22,742 \\
\hline \multirow[t]{2}{*}{ Of which: Non-mining private GDP } & 10,489 & 11,041 & 12,013 & 12,677 & 12,921 \\
\hline & \multicolumn{5}{|c|}{ (Annual percentage change) } \\
\hline Agriculture & 9.9 & -2.6 & 1.9 & 2.8 & 3.3 \\
\hline Mining & 17.6 & -3.0 & 10.6 & 0.3 & 18.2 \\
\hline Manufacturing & -0.3 & 0.0 & 3.1 & 0.8 & -2.6 \\
\hline Water and electricity & 5.4 & 3.7 & 9.5 & 6.4 & 3.3 \\
\hline Construction & 1.6 & 4.7 & 0.6 & 2.1 & 0.7 \\
\hline Trade and hotels & 6.5 & 8.2 & 8.2 & 11.3 & -6.6 \\
\hline Transport & 5.0 & 0.3 & 0.9 & -3.4 & 5.6 \\
\hline Banking, insurance, and business services & 5.1 & 7.1 & 2.6 & 2.4 & 4.1 \\
\hline General government & 6.7 & 8.3 & 3.7 & 5.1 & 3.6 \\
\hline Social and personal services & 2.8 & 6.2 & 2.6 & 7.0 & -0.5 \\
\hline Adjustment items & -9.9 & -7.6 & 68.7 & 15.6 & 13.8 \\
\hline GDP at constant prices & 8.6 & 2.1 & 7.8 & 3.4 & 8.4 \\
\hline Of which: Non-mining private GDP & 4.1 & 5.1 & 6.4 & 5.5 & 1.9 \\
\hline
\end{tabular}

Source: Central Statistics Office.

1/ National accounts year beginning July 1. 
Table 5. Botswana: Beef Sales, 2000-2005 1/

\begin{tabular}{lllllll}
\hline & 2000 & 2001 & 2002 & 2003 & 2004 & 2005 \\
\hline
\end{tabular}

Boneless beef sales by category

(In thousands of tons)

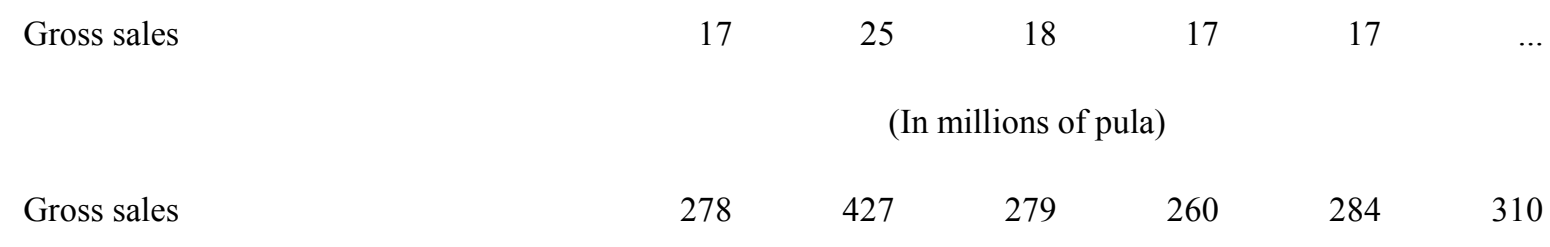

Beef sales by country

Total
United Kingdom
South Africa
Other

Total

United Kingdom

South Africa

Other
(In thousands of tons)

\begin{tabular}{|c|c|c|c|c|}
\hline 17 & 25 & 16 & 17 & 17 \\
\hline 11 & 15 & 10 & 9 & 9 \\
\hline 3 & 6 & 3 & 5 & 3 \\
\hline 4 & 4 & 4 & 3 & 4 \\
\hline
\end{tabular}

(In millions of pula)

$\begin{array}{rrrrrr}278 & 427 & 279 & 260 & 284 & 310 \\ 138 & 253 & 162 & 134 & 152 & 115 \\ 28 & 61 & 30 & 48 & 42 & 55 \\ 112 & 113 & 87 & 78 & 90 & 140\end{array}$

Memorandum item:

$$
\text { (In thousands) }
$$

Total cattle processed

185

120

144

135

Source: Ministry of Agriculture.

1/ Calendar year. 
Table 6. Botswana: Mineral Production and Value, 2000-2005

\begin{tabular}{|c|c|c|c|c|c|c|}
\hline & 2000 & 2001 & 2002 & 2003 & 2004 & 2005 \\
\hline \multicolumn{7}{|l|}{ Diamonds } \\
\hline Volume (in millions of carats) & 25.0 & 26.0 & 28.4 & 30.4 & 31.0 & 31.8 \\
\hline \multicolumn{7}{|l|}{ Copper-nickel matte } \\
\hline Value (in millions of pula) & 801.0 & 901.0 & 428.0 & $1,052.3$ & $1,223.0$ & $1,675.8$ \\
\hline Volume (in thousands of tons) & 46.0 & 42.0 & 45.8 & 52.0 & 44.1 & 50.4 \\
\hline Unit value (in pula per ton) & $17,413.0$ & $21,451.6$ & $9,337.0$ & $20,242.4$ & $27,706.2$ & $33,259.0$ \\
\hline \multicolumn{7}{|l|}{ Coal } \\
\hline Value (in millions of pula) 1/ & 30.0 & 29.0 & 30.0 & 25.9 & 28.7 & 28.2 \\
\hline Volume (in thousands of tons) & 947.0 & 930.0 & 953.0 & 822.8 & 911.0 & 894.7 \\
\hline Unit value (in pula per ton) & 31.0 & 32.0 & 32.0 & 31.5 & 31.5 & 31.5 \\
\hline \multicolumn{7}{|l|}{ Soda ash } \\
\hline Value (in millions of pula) 1/ & 122.0 & 186.0 & 210.0 & 173.8 & 218.4 & 218.4 \\
\hline Volume (in thousands of tons) & 190.0 & 251.0 & 283.0 & 234.5 & 264.7 & 263.7 \\
\hline Unit value (in pula per ton) & 639.0 & 741.0 & 741.0 & 741.0 & 825.0 & 828.1 \\
\hline \multicolumn{7}{|l|}{ Salt } \\
\hline Value (in millions of pula) 1/ & 32.0 & 37.0 & 65.0 & 47.3 & 46.0 & 38.5 \\
\hline Volume (in thousands of tons) & 185.0 & 179.0 & 315.0 & 229.4 & 216.7 & 181.4 \\
\hline Unit value (in pula per ton) & 175.0 & 206.0 & 206.0 & 206.0 & 212.0 & 212.0 \\
\hline
\end{tabular}

Source: Central Statistics Office and Department of Mines.

1/ Estimated value of production. 
Table 7. Botswana: Agricultural Producer Prices, 1998/99-2004/05 1/ (Pula per ton)

\begin{tabular}{lrrrrrrr}
\hline & $1998 / 99$ & $1999 / 00$ & $2000 / 01$ & $2001 / 02$ & $2002 / 03$ & $2003 / 04$ & $2004 / 05$ \\
& & & & & & & \\
\hline & 486 & 574 & 548 & 1,200 & 1,200 & 1,200 & 1,150 \\
Sorghum & 466 & 644 & 508 & 933 & 933 & 950 & 720 \\
White maize & 783 & 876 & 2,832 & 3,908 & 1,130 & 1,240 & 4,550 \\
Pulses & 625 & 728 & 713 & 1,531 & 1,531 & 810 & 1,160 \\
Sunflower seeds & 1,356 & 1,491 & 1,642 & 2,366 & 1,002 & 1,370 & 1,760 \\
Shelled groundnuts & & & & & & & \\
&
\end{tabular}

Source: Botswana Agricultural Marketing Board.

1/ Crop year beginning April 1. 
Table 8. Botswana: Formal Sector Employment, 2000/01-2004/05 1/

(Number of employees, unless otherwise indicated)

\begin{tabular}{|c|c|c|c|c|c|c|}
\hline & $2000 / 01$ & $2001 / 02$ & $2002 / 03$ & $2003 / 04$ & $2004 / 052 /$ & $2005 / 063 /$ \\
\hline Private and parastatal & 180,100 & 182,193 & 169,519 & 174,483 & 178,854 & 177,352 \\
\hline Private & 166,600 & 155,062 & 155,936 & 160,861 & 166,759 & 164,489 \\
\hline Parastatal & 13,500 & 13,564 & 13,583 & 13,622 & 12,095 & 12,863 \\
\hline Agriculture & 6,000 & 6,206 & 5,975 & 6,264 & 5,262 & 5,554 \\
\hline Mining and quarrying & 8,300 & 6,962 & 7,508 & 7,968 & 9,705 & 9,270 \\
\hline Manufacturing & 30,900 & 30,287 & 29,789 & 30,169 & 32,621 & 32,396 \\
\hline Electricity and water & 2,900 & 2,752 & 3,064 & 2,825 & 2,515 & 2,430 \\
\hline Construction & 28,500 & 28,785 & 28,895 & 29,750 & 25,347 & 24,364 \\
\hline Commerce & 49,900 & 53,527 & 53,792 & 55,288 & 56,164 & 55,979 \\
\hline Transport and communications & 10,100 & 9,854 & 10,136 & 10,277 & 12,700 & 12,608 \\
\hline Finance and business services & 19,200 & 18,266 & 18,263 & 19,025 & 21,476 & 21,763 \\
\hline Community and personal services & 4,300 & 5,249 & 5,327 & 5,796 & 5,177 & 5,137 \\
\hline Education & 6,500 & 6,741 & 6,772 & 7,121 & 7,888 & 7,850 \\
\hline General government & 106,400 & 105,156 & 109,380 & 110,900 & 117,533 & 121,364 \\
\hline Central government & 85,400 & 83,077 & 86,958 & 87,700 & 94,753 & 96,702 \\
\hline Local government & 21,000 & 22,079 & 22,422 & 23,200 & 22,780 & 24,662 \\
\hline Total & 286,500 & 287,349 & 278,899 & 285,382 & 296,387 & 298,716 \\
\hline
\end{tabular}

Sources: Central Statistics Office.

1/ Data for September of first year listed.

2/ The increase in central government employment reflects the absorption of community, junior, and secondary school staff, the salaries of which were already being paid by the central government.

3/ Data for March 2005. 
Table 9. Botswana: Statutory Minimum Hourly Wage Rates, 2000-2006

\begin{tabular}{|c|c|c|c|c|c|c|c|}
\hline & 2000 & 2001 & 2002 & 2003 & 2004 & 2005 & $\begin{array}{r}2006 \\
\text { May } \\
\end{array}$ \\
\hline & \multicolumn{7}{|c|}{ (In thebe) $1 /$} \\
\hline Manufacturing, service, and repair trades & 205 & 225 & 240 & 260 & 290 & 310 & 335 \\
\hline Building, construction, exploration, and quarrying & 205 & 225 & 240 & 260 & 290 & 310 & 335 \\
\hline Hotel, catering, and entertainment & 205 & 225 & 240 & 240 & 290 & 310 & 335 \\
\hline Garages, motor trade, and road transport & 205 & 225 & 225 & 260 & 255 & 270 & 290 \\
\hline Wholesale distributive trade & 205 & 225 & 240 & 260 & 290 & 310 & 335 \\
\hline Retail distributive trade & 185 & 205 & 215 & 230 & 290 & 310 & 335 \\
\hline Retail and wholesale nightwatchmen & 180 & 200 & 210 & 210 & 290 & 260 & 280 \\
\hline \multirow[t]{2}{*}{ Other nightwatchmen } & 205 & 225 & 240 & 260 & 290 & 310 & 335 \\
\hline & \multicolumn{7}{|c|}{ (Annual growth rate, in percent) } \\
\hline Manufacturing, service, and repair trades & 7.9 & 9.8 & 6.7 & 8.3 & 11.5 & 6.9 & 8.1 \\
\hline Building, construction, exploration, and quarrying & 7.9 & 9.8 & 6.7 & 8.3 & 11.5 & 6.9 & 8.1 \\
\hline Hotel, catering, and entertainment & 7.9 & 9.8 & 6.7 & 0.0 & 20.8 & 6.9 & 8.1 \\
\hline Garages, motor trade, and road transport & 7.9 & 9.8 & 0.0 & 15.6 & -1.9 & 5.9 & 7.4 \\
\hline Wholesale distributive trade & 13.9 & 9.8 & 6.7 & 8.3 & 11.5 & 6.9 & 8.1 \\
\hline Retail distributive trade & 8.8 & 10.8 & 4.9 & 7.0 & 26.1 & 6.9 & 8.1 \\
\hline Retail and wholesale nightwatchmen & 9.1 & 11.1 & 5.0 & 0.0 & 38.1 & -10.3 & 7.7 \\
\hline Other nightwatchmen & 7.9 & 9.8 & 6.7 & 8.3 & 11.5 & 6.9 & 8.1 \\
\hline
\end{tabular}

Source: Central Statistics Office.

$1 / 100$ thebe $=1$ pula. 
Table 10. Botswana: Average Monthly Cash Earnings by Sector, 1999-2003 1/

\begin{tabular}{|c|c|c|c|c|c|}
\hline & 1999 & 2000 & 2001 & 2002 & 2003 \\
\hline & \multicolumn{5}{|c|}{ (In pula) } \\
\hline Citizens & 1428 & 1546 & 1723 & 1973 & 2119 \\
\hline Private and parastatal & 1,243 & 1605 & 1414 & 1560 & 1719 \\
\hline Agriculture & 383 & 434 & 409 & 563 & 542 \\
\hline Mining and quarrying & 2,249 & 3,010 & 2,423 & 3,206 & 3,362 \\
\hline Manufacturing & 785 & 1096 & 835 & 849 & 944 \\
\hline Electricity and water & 3,166 & 3,616 & 3,525 & 4,517 & 5,569 \\
\hline Construction & 776 & 1006 & 917 & 997 & 1050 \\
\hline Commerce & 953 & 1,001 & 1,179 & 989 & 1,253 \\
\hline Transport and communications & 2,318 & 2,689 & 2,616 & 3,510 & 3,597 \\
\hline Finance and business services & 1,979 & 2,164 & 2,251 & 3,056 & 3,080 \\
\hline Community and personal services & 1,413 & 1,669 & 1,660 & 1,998 & 1,965 \\
\hline Education & 2,261 & 3,069 & 2,775 & 2,895 & 2,830 \\
\hline Local government & 1,496 & 1,732 & 1,948 & 1,866 & 2,502 \\
\hline Central government & 1,733 & 2,001 & 2,232 & 2,804 & 2,781 \\
\hline Non-citizens & 5260 & 5410 & 5907 & 6601 & 7387 \\
\hline Private and parastatal & 5257 & 5424 & 5865 & 6655 & 7518 \\
\hline Local government & 5091 & 4968 & 6018 & 7538 & 6888 \\
\hline Central government & 5292 & 5391 & 6073 & 6342 & 6755 \\
\hline \multirow[t]{2}{*}{ Total } & 1680 & 1742 & 1945 & 2217 & 2396 \\
\hline & \multicolumn{5}{|c|}{ (Annual percentage change) } \\
\hline Citizens & 14.1 & 8.3 & 11.4 & 14.5 & 7.4 \\
\hline Private and parastatal & 16.5 & 29.1 & -11.9 & 10.3 & 10.2 \\
\hline Agriculture & 10.7 & 13.3 & -5.8 & 37.7 & -3.7 \\
\hline Mining and quarrying & 15.3 & 33.8 & -19.5 & 32.3 & 4.9 \\
\hline Manufacturing & 24.2 & 39.6 & -23.8 & 1.7 & 11.2 \\
\hline Electricity and water & 55.0 & 14.2 & -2.5 & 28.1 & 23.3 \\
\hline Construction & 2.9 & 29.6 & -8.8 & 8.7 & 5.3 \\
\hline Commerce & 9.9 & 5.0 & 17.8 & -16.2 & 26.7 \\
\hline Transport and communications & 34.4 & 16.0 & -2.7 & 34.2 & 2.5 \\
\hline Finance and business services & 24.2 & 9.3 & 4.0 & 35.8 & 0.8 \\
\hline Community and personal services & 13.1 & 18.1 & -0.5 & 20.4 & -1.6 \\
\hline Education & 14.0 & 35.7 & -9.6 & 4.3 & -2.2 \\
\hline Local government & 25.7 & 15.8 & 12.5 & -4.2 & 34.1 \\
\hline Central government & 10.7 & 15.5 & 11.5 & 25.6 & -0.8 \\
\hline Non-citizens & 13.7 & 2.9 & 9.2 & 11.7 & 11.9 \\
\hline Private and parastatal & 7.2 & 3.2 & 8.1 & 13.5 & 13.0 \\
\hline Local government & 29.6 & -2.4 & 21.1 & 25.3 & -8.6 \\
\hline Central government & 46.1 & 1.9 & 12.7 & 4.4 & 6.5 \\
\hline Total & 17.5 & 3.7 & 11.7 & 14.0 & 8.1 \\
\hline
\end{tabular}

Source: Central Statistics Office.

1/ Based on the formal sector employment survey in March each year except for 1999, in which the survey was conducted in September. 
Table 11. Botswana: Consumer Price Index of Tradables and Nontradables, 1999-2006

\begin{tabular}{|c|c|c|c|c|c|c|c|c|c|c|}
\hline & $\begin{array}{l}\text { All Items } \\
\text { Index }\end{array}$ & $\begin{array}{l}\text { Inflation } \\
\text { (Percent } \\
\text { change) }\end{array}$ & $\begin{array}{l}\text { Non- } \\
\text { Tradables } \\
\text { Index }\end{array}$ & $\begin{array}{l}\text { Inflation } \\
\text { (Percent } \\
\text { change) }\end{array}$ & $\begin{array}{l}\text { Domestic } \\
\text { Tradeables } \\
\text { Index }\end{array}$ & $\begin{array}{l}\text { Inflation } \\
\text { (Percent } \\
\text { change) }\end{array}$ & $\begin{array}{l}\text { Imported } \\
\text { Tradeables } \\
\text { Index }\end{array}$ & $\begin{array}{l}\text { Inflation } \\
\text { (Percent } \\
\text { change) }\end{array}$ & $\begin{array}{l}\text { All } \\
\text { Tradeables } \\
\text { Index }\end{array}$ & $\begin{array}{l}\text { Inflation } \\
\text { (Percent } \\
\text { change) }\end{array}$ \\
\hline Weights & 100.0 & & 29.2 & & 23.8 & & 47.0 & & 70.8 & \\
\hline $1999 \mathrm{Dec}$ & 125.0 & 8.4 & 125.1 & 12.0 & 121.8 & 6.7 & 127.1 & 7.9 & 125.3 & 7.5 \\
\hline $2000 \mathrm{Dec}$ & 135.6 & 8.5 & 136.4 & 9.0 & 129.5 & 6.3 & 138.2 & 8.7 & 135.3 & 8.0 \\
\hline $2001 \mathrm{Dec}$ & 143.4 & 5.8 & 147.0 & 7.8 & 137.1 & 5.9 & 144.7 & 4.7 & 142.1 & 5.0 \\
\hline $2002 \mathrm{Dec}$ & 158.6 & 10.6 & 161.4 & 9.8 & 158.0 & 15.2 & 156.5 & 8.2 & 157.2 & 10.6 \\
\hline 2003 Dec & 168.7 & 6.4 & 174.6 & 8.2 & 167.6 & 6.1 & 165.1 & 5.5 & 166.2 & 5.7 \\
\hline 2004 Jan & 169.3 & 6.2 & 176.4 & 8.0 & 168.1 & 5.4 & 165.2 & 5.5 & 166.4 & 5.5 \\
\hline Feb & 171.0 & 6.3 & 177.1 & 8.0 & 169.5 & 5.5 & 167.7 & 5.9 & 168.6 & 5.8 \\
\hline Mar & 172.7 & 6.9 & 179.1 & 8.5 & 170.9 & 5.7 & 169.3 & 6.6 & 170.1 & 6.3 \\
\hline Apr & 174.5 & 6.6 & 179.4 & 8.0 & 173.2 & 5.8 & 171.7 & 6.2 & 172.5 & 6.0 \\
\hline May & 177.0 & 7.4 & 186.4 & 11.9 & 174.3 & 5.6 & 172.4 & 5.8 & 173.3 & 5.7 \\
\hline Jun & 178.2 & 6.7 & 186.5 & 7.7 & 175.3 & 5.9 & 174.3 & 6.5 & 174.9 & 6.3 \\
\hline Jul & 178.1 & 6.8 & 186.9 & 7.8 & 174.7 & 5.6 & 174.1 & 6.6 & 174.6 & 6.3 \\
\hline Aug & 178.7 & 6.7 & 188.4 & 8.7 & 175.0 & 4.8 & 174.4 & 6.5 & 174.9 & 6.0 \\
\hline Sep & 179.7 & 7.0 & 189.3 & 9.0 & 176.2 & 4.9 & 175.4 & 7.0 & 176.0 & 6.3 \\
\hline Oct & 180.9 & 7.7 & 191.7 & 10.4 & 176.5 & 5.1 & 176.3 & 7.6 & 176.7 & 6.7 \\
\hline Nov & 181.3 & 7.6 & 191.9 & 10.0 & 176.6 & 5.4 & 177.0 & 7.4 & 177.1 & 6.7 \\
\hline Dec & 181.9 & 7.8 & 192.4 & 10.2 & 177.1 & 5.6 & 177.6 & 7.6 & 177.6 & 6.9 \\
\hline 2005 Jan & 182.9 & 8.0 & 194.0 & 10.0 & 177.4 & 5.5 & 178.8 & 8.2 & 178.5 & 7.3 \\
\hline Feb & 183.5 & 7.3 & 195.0 & 10.2 & 177.9 & 5.0 & 179.2 & 6.8 & 179.0 & 6.2 \\
\hline Mar & 184.0 & 6.5 & 195.3 & 9.0 & 178.5 & 4.4 & 179.9 & 6.3 & 179.6 & 5.6 \\
\hline Apr & 185.3 & 6.2 & 195.4 & 8.9 & 180.1 & 4.0 & 181.6 & 5.7 & 181.3 & 5.2 \\
\hline May & 188.2 & 6.3 & 196.9 & 5.6 & 180.8 & 3.7 & 186.5 & 8.2 & 184.8 & 6.7 \\
\hline Jun & 190.9 & 7.1 & 197.6 & 5.9 & 185.2 & 5.6 & 189.5 & 8.7 & 188.3 & 7.7 \\
\hline Jul & 192.8 & 8.2 & 197.7 & 5.8 & 187.4 & 7.3 & 192.3 & 10.4 & 190.8 & 9.3 \\
\hline Aug & 196.0 & 9.6 & 198.1 & 5.1 & 189.5 & 8.3 & 197.7 & 13.3 & 195.0 & 11.5 \\
\hline Sep & 197.7 & 10.0 & 199.4 & 5.4 & 191.1 & 8.4 & 199.7 & 13.8 & 196.8 & 11.9 \\
\hline Oct & 201.2 & 11.2 & 203.3 & 6.0 & 192.4 & 9.0 & 204.3 & 15.8 & 200.3 & 13.4 \\
\hline Nov & 201.8 & 11.3 & 203.5 & 6.1 & 193.2 & 9.4 & 204.9 & 15.8 & 201.1 & 13.5 \\
\hline Dec & 202.6 & 11.4 & 203.9 & 6.0 & 194.0 & 9.6 & 205.7 & 15.8 & 201.9 & 13.6 \\
\hline 2006 Jan & 206.1 & 12.7 & 210.7 & 8.7 & 197.6 & 11.4 & 207.4 & 16.0 & 204.3 & 14.5 \\
\hline Feb & 207.5 & 13.1 & 213.0 & 9.2 & 200.0 & 12.4 & 208.0 & 16.1 & 205.5 & 14.9 \\
\hline Mar & 209.3 & 13.8 & 213.2 & 9.2 & 203.8 & 14.2 & 209.7 & 16.6 & 208.0 & 15.8 \\
\hline Apr & 211.6 & 14.2 & 215.5 & 10.3 & 206.3 & 14.5 & 212.0 & 16.7 & 210.3 & 16.0 \\
\hline May & 213.6 & 13.5 & 215.5 & 9.5 & 208.4 & 15.3 & 214.9 & 15.2 & 212.9 & 15.2 \\
\hline
\end{tabular}

Source: Central Statistics Office. 
Table 12. Botswana: Cost of Living Index, 1999-2006 (Index; November 1996=100)

\begin{tabular}{|c|c|c|c|c|c|c|c|c|c|c|c|c|c|c|}
\hline & Food & $\begin{array}{l}\text { Alcohol } \\
\text { and } \\
\text { Tobacco }\end{array}$ & $\begin{array}{l}\text { Clothing } \\
\text { and } \\
\text { Footwear }\end{array}$ & Housing & $\begin{array}{c}\text { Fuel } \\
\text { and } \\
\text { Power }\end{array}$ & $\begin{array}{c}\text { Furniture } \\
\text { etc. }\end{array}$ & $\begin{array}{c}\mathrm{H} / \text { hold } \\
\text { Operation }\end{array}$ & $\begin{array}{l}\text { Health, } \\
\text { Personal } \\
\text { Care }\end{array}$ & $\begin{array}{c}\text { Transport } \\
\text { etc. }\end{array}$ & Leisure & Education & Other & $\begin{array}{l}\text { All items } \\
\text { Index }\end{array}$ & $\begin{array}{l}\text { Annual } \\
\text { inflation }\end{array}$ \\
\hline Weights & 25.5 & 13.5 & 5.8 & 12.2 & 2.6 & 5.1 & 3.9 & 5.7 & 19.7 & 1.6 & 3.8 & 0.6 & 100.0 & $\%$ \\
\hline 1999 Dec. & 122.1 & 134.9 & 117.4 & 122.1 & 134.9 & 117.4 & 126.0 & 118.5 & 123.7 & 129.2 & 116.8 & 123.2 & 109.8 & 8.4 \\
\hline 2000 Dec. & 127.1 & 146.9 & 120.6 & 145.5 & 145.2 & 134.4 & 141.9 & 120.7 & 142.2 & 111.3 & 143.2 & 134.5 & 135.6 & 8.5 \\
\hline 2001 Dec. & 132.3 & 158.9 & 125.7 & 158.7 & 149.5 & 136.7 & 153.2 & 123.8 & 149.0 & 116.0 & 147.6 & 139.3 & 143.4 & 5.8 \\
\hline $2002 \mathrm{Dec}$ & 151.2 & 179.0 & 130.9 & 175.4 & 163.0 & 145.6 & 166.8 & 133.0 & 164.6 & 124.2 & 164.8 & 172.0 & 158.6 & 10.6 \\
\hline 2003 Dec & 160.1 & 188.2 & 135.8 & 194.7 & 159.8 & 150.7 & 174.2 & 142.1 & 170.2 & 126.7 & 177.7 & 179.1 & 168.7 & 6.4 \\
\hline 2004 Jan & 160.8 & 188.0 & 136.2 & 195.0 & 158.6 & 150.9 & 173.2 & 142.3 & 170.2 & 125.8 & 192.0 & 179.2 & 169.3 & 6.2 \\
\hline Feb & 161.4 & 190.3 & 136.7 & 195.6 & 158.6 & 151.4 & 173.9 & 143.1 & 175.7 & 127.5 & 192.0 & 180.0 & 171.0 & 6.3 \\
\hline Mar & 163.1 & 192.7 & 136.1 & 196.8 & 162.7 & 150.5 & 173.4 & 145.0 & 178.9 & 127.1 & 192.0 & 184.5 & 172.7 & 6.9 \\
\hline Apr & 165.5 & 195.9 & 136.4 & 197.5 & 166.3 & 151.0 & 175.7 & 146.0 & 181.1 & 128.7 & 192.1 & 184.7 & 174.5 & 6.6 \\
\hline May & 166.1 & 199.3 & 135.9 & 212.2 & 167.0 & 150.8 & 174.5 & 145.7 & 181.3 & 128.4 & 192.3 & 184.2 & 177.0 & 7.4 \\
\hline Jun & 167.0 & 200.4 & 136.1 & 211.4 & 172.2 & 151.4 & 176.8 & 146.9 & 184.6 & 128.6 & 192.3 & 185.1 & 178.2 & 6.7 \\
\hline Jul & 165.9 & 200.0 & 136.8 & 211.8 & 173.4 & 151.7 & 176.6 & 147.3 & 184.7 & 129.2 & 192.3 & 191.4 & 178.1 & 6.8 \\
\hline Aug & 166.3 & 200.1 & 137.0 & 212.0 & 173.4 & 152.3 & 177.7 & 147.5 & 188.7 & 129.5 & 192.3 & 191.2 & 178.7 & 6.7 \\
\hline Sep & 166.6 & 201.8 & 136.7 & 213.1 & 176.0 & 153.5 & 181.3 & 147.8 & 190.6 & 128.5 & 192.3 & 192.2 & 179.7 & 7.0 \\
\hline Oct & 167.3 & 203.5 & 137.1 & 214.9 & 175.8 & 153.5 & 181.9 & 147.6 & 194.0 & 129.0 & 192.3 & 192.6 & 180.9 & 7.7 \\
\hline Nov & 167.4 & 204.8 & 136.8 & 215.7 & 177.2 & 152.7 & 182.6 & 148.0 & 194.2 & 130.3 & 192.3 & 193.5 & 181.3 & 7.6 \\
\hline Dec & 168.0 & 205.4 & 137.4 & 216.4 & 179.1 & 153.7 & 183.6 & 149.0 & 194.3 & 130.7 & 192.3 & 194.1 & 181.9 & 7.8 \\
\hline $2005 \mathrm{Jan}$ & 168.4 & 206.1 & 137.6 & 217.1 & 179.0 & 154.1 & 184.3 & 149.3 & 196.1 & 132.2 & 203.2 & 193.8 & 182.9 & 8.0 \\
\hline Feb & 168.0 & 208.1 & 138.7 & 217.3 & 179.5 & 153.9 & 184.4 & 149.5 & 196.1 & 133.2 & 211.1 & 193.6 & 183.5 & 7.3 \\
\hline Mar & 168.0 & 210.5 & 138.9 & 217.7 & 179.9 & 154.2 & 185.9 & 149.7 & 196.1 & 133.5 & 211.1 & 193.9 & 184.0 & 6.5 \\
\hline Apr & 169.6 & 214.2 & 140.3 & 218.8 & 181.0 & 154.5 & 186.0 & 150.1 & 196.2 & 134.7 & 211.1 & 198.3 & 185.3 & 6.2 \\
\hline May & 169.0 & 216.2 & 140.4 & 219.2 & 186.9 & 156.2 & 186.7 & 150.8 & 209.0 & 134.7 & 214.1 & 198.9 & 188.2 & 6.3 \\
\hline Jun & 172.3 & 224.7 & 138.5 & 220.8 & 189.6 & 157.7 & 191.7 & 151.9 & 209.4 & 133.3 & 214.1 & 204.3 & 190.9 & 7.1 \\
\hline Jul & 175.2 & 229.4 & 137.5 & 221.9 & 195.6 & 157.7 & 196.4 & 152.6 & 209.5 & 134.7 & 214.1 & 205.4 & 192.8 & 8.2 \\
\hline Aug & 177.1 & 233.8 & 138.8 & 222.9 & 207.7 & 159.6 & 196.9 & 153.5 & 218.4 & 135.5 & 214.1 & 202.1 & 196.0 & 9.6 \\
\hline Sep & 179.1 & 236.3 & 139.9 & 224.0 & 219.4 & 161.4 & 199.5 & 153.8 & 218.6 & 136.6 & 214.1 & 203.2 & 197.7 & 10.0 \\
\hline Oct & 180.6 & 238.6 & 139.9 & 224.4 & 225.8 & 163.1 & 201.2 & 155.4 & 233.4 & 136.8 & 214.1 & 203.6 & 201.2 & 11.2 \\
\hline Nov & 182.1 & 239.0 & 139.2 & 225.2 & 225.7 & 164.3 & 202.4 & 155.0 & 233.8 & 136.1 & 214.1 & 204.3 & 201.8 & 11.3 \\
\hline Dec & 182.8 & 240.1 & 140.0 & 226.0 & 226.9 & 166.4 & 203.4 & 155.0 & 233.4 & 137.1 & 214.1 & 204.0 & 202.6 & 11.4 \\
\hline 2006 Jan & 186.5 & 240.7 & 140.8 & 226.7 & 225.7 & 167.0 & 204.4 & 156.6 & 235.9 & 137.2 & 263.6 & 205.0 & 206.1 & 12.7 \\
\hline Feb & 188.4 & 242.9 & 139.7 & 229.0 & 225.8 & 167.9 & 204.9 & 161.5 & 236.2 & 139.8 & 263.7 & 206.6 & 207.5 & 13.1 \\
\hline Mar & 191.2 & 246.8 & 139.5 & 231.2 & 231.4 & 169.3 & 207.8 & 162.3 & 236.4 & 138.8 & 264.3 & 205.9 & 209.3 & 13.8 \\
\hline Apr & 194.1 & 250.2 & 140.1 & 231.8 & 234.5 & 171.9 & 208.0 & 164.3 & 239.7 & 139.1 & 264.3 & 206.4 & 211.6 & 14.2 \\
\hline May & 196.6 & 251.8 & 139.6 & 231.5 & 254.4 & 173.8 & 208.4 & 165.4 & 243.0 & 138.6 & 264.5 & 207.0 & 213.6 & 13.5 \\
\hline
\end{tabular}

Source: Central Statistics Office. 
Table 13. Botswana: Liquid Fuel Import and Retail Prices, 2002-2006 (In pula, unless otherwise indicated; end of period)

\begin{tabular}{|c|c|c|c|c|c|}
\hline & 2002 & 2003 & 2004 & 2005 & $\begin{array}{l}2006 \\
\text { May }\end{array}$ \\
\hline & \multicolumn{5}{|c|}{ (In pula per liter) } \\
\hline \multicolumn{6}{|l|}{ Gasoline } \\
\hline Import price 1/ & 1.48 & 1.49 & 1.98 & 2.68 & 3.51 \\
\hline Retail price & 2.33 & 2.33 & 2.97 & 4.02 & 4.16 \\
\hline \multicolumn{6}{|l|}{ Kerosene } \\
\hline Import price 1/ & 1.58 & 1.40 & 2.04 & 3.10 & 3.59 \\
\hline Retail price & 1.96 & 1.91 & 2.34 & 3.20 & 4.08 \\
\hline \multicolumn{6}{|l|}{ Diesel } \\
\hline Import price 1/ & 1.56 & 1.33 & 1.93 & 2.91 & 3.74 \\
\hline Retail price & 2.15 & 2.18 & 2.74 & 3.94 & 4.41 \\
\hline \multicolumn{6}{|l|}{ Memorandum items: } \\
\hline Gasoline retail price in U.S. dollar & 0.43 & 0.52 & 0.69 & 0.73 & 0.72 \\
\hline U.S. dollars per pula (end of period) & 0.18 & 0.23 & 0.23 & 0.18 & 0.17 \\
\hline
\end{tabular}

Source: Ministry of Minerals, Energy and Water Resources.

1/ Import Parity Gaborone. 
Table 14. Botswana: Central Government Operations, 2000/01-2006/07 1/

\begin{tabular}{|c|c|c|c|c|c|c|c|}
\hline & $2000 / 01$ & $2001 / 02$ & $2002 / 03$ & $\begin{array}{r}2003 / 04 \\
\text { Rev. }\end{array}$ & $\begin{array}{r}2004 / 05 \\
\text { Rev. }\end{array}$ & $\begin{array}{r}2005 / 06 \\
\text { Prel. }\end{array}$ & $\begin{array}{r}2006 / 07 \\
\text { Bud. }\end{array}$ \\
\hline & \multicolumn{5}{|c|}{ (In millions of pula) } & & \\
\hline Total revenue and grants & 14,050 & 12,601 & 14,240 & 16,119 & 17,819 & 22,535 & 24,105 \\
\hline Total revenue & 13,986 & 12,542 & 14,155 & 16,057 & 17,472 & 22,244 & 23,742 \\
\hline Tax revenue & 12,078 & 10,582 & 12,259 & 14,146 & 16,245 & 20,124 & 21,916 \\
\hline Mineral revenue & 8,368 & 6,996 & 7,503 & 8,163 & 8,682 & 11,045 & 11,389 \\
\hline Trade and excise taxes $2 /$ & 2,188 & 1,732 & 1,569 & 2,246 & 3,226 & 3,930 & 5,300 \\
\hline General sales tax & 524 & 520 & 1,255 & 1,573 & 2,116 & 1,978 & 2,118 \\
\hline Other & 998 & 1,334 & 1,933 & 2,165 & 2,221 & 3,170 & 3,109 \\
\hline Nontax revenue & 1,908 & 1,960 & 1,896 & 1,911 & 1,226 & 2,121 & 1,826 \\
\hline Interest & 205 & 189 & 227 & 208 & -97 & 78 & 36 \\
\hline Property income & 1,195 & 1,170 & 1,064 & 969 & 433 & 913 & 704 \\
\hline Other & 508 & 601 & 605 & 733 & 891 & 1,130 & 1,086 \\
\hline Grants & 65 & 59 & 84 & 61 & 348 & 290 & 363 \\
\hline Total expenditure and lending & 11,536 & 13,671 & 15,710 & 16,275 & 17,383 & 17,881 & 23,223 \\
\hline Current expenditure & 8,383 & 9,935 & 11,581 & 12,934 & 13,765 & 14,086 & 17,234 \\
\hline Wages and salaries & 2,743 & 3,446 & 3,947 & 4,142 & 5,129 & 5,248 & 5,998 \\
\hline Interest & 83 & 94 & 81 & 193 & 315 & 317 & 278 \\
\hline Other & 5,557 & 6,394 & 7,553 & 8,600 & 8,322 & 8,520 & 10,959 \\
\hline Capital expenditure & 3,135 & 3,698 & 4,200 & 4,256 & 3,910 & 3,851 & 6,035 \\
\hline Net lending & 19 & 38 & -71 & -916 & -293 & -56 & -47 \\
\hline Primary balance (deficit -) & 2,597 & -975 & $-1,389$ & 36 & 751 & 4,971 & 1,160 \\
\hline \multirow[t]{2}{*}{ Overall balance (deficit -) } & 2,514 & $-1,069$ & $-1,471$ & -157 & 437 & 4,654 & 882 \\
\hline & \multicolumn{7}{|c|}{ (In percent of GDP) } \\
\hline Total revenue and grants & 42.4 & 35.5 & 37.0 & 38.6 & 37.7 & 41.2 & 39.5 \\
\hline Total revenue & 42.2 & 35.4 & 36.7 & 38.4 & 37.0 & 40.7 & 38.9 \\
\hline Tax revenue & 36.4 & 29.8 & 31.8 & 33.8 & 34.4 & 36.8 & 35.9 \\
\hline Mineral revenue & 25.2 & 19.7 & 19.5 & 19.5 & 18.4 & 20.2 & 18.7 \\
\hline Trade and excise taxes $2 /$ & 6.6 & 4.9 & 4.1 & 5.4 & 6.8 & 7.2 & 8.7 \\
\hline General sales tax & 1.6 & 1.5 & 3.3 & 3.8 & 4.5 & 3.6 & 3.5 \\
\hline Other & 3.0 & 3.8 & 5.0 & 5.2 & 4.7 & 5.8 & 5.1 \\
\hline Nontax revenue & 5.8 & 5.5 & 4.9 & 4.6 & 2.6 & 3.9 & 3.0 \\
\hline Interest & 0.6 & 0.5 & 0.6 & 0.5 & -0.2 & 0.1 & 0.1 \\
\hline Property income & 3.6 & 3.3 & 2.8 & 2.3 & 0.9 & 1.7 & 1.2 \\
\hline Other & 1.5 & 1.7 & 1.6 & 1.8 & 1.9 & 2.1 & 1.8 \\
\hline Grants & 0.2 & 0.2 & 0.2 & 0.1 & 0.7 & 0.5 & 0.6 \\
\hline Total expenditure and lending & 34.8 & 38.5 & 40.8 & 38.9 & 36.8 & 32.7 & 38.1 \\
\hline Current expenditure & 25.3 & 28.0 & 30.1 & 30.9 & 29.2 & 25.7 & 28.3 \\
\hline Wages and salaries & 8.3 & 9.7 & 10.2 & 9.9 & 10.9 & 9.6 & 9.8 \\
\hline Interest & 0.3 & 0.3 & 0.2 & 0.5 & 0.7 & 0.6 & 0.5 \\
\hline Other & 16.8 & 18.0 & 19.6 & 20.6 & 17.6 & 15.6 & 18.0 \\
\hline Capital expenditure & 9.5 & 10.4 & 10.9 & 10.2 & 8.3 & 7.0 & 9.9 \\
\hline Net lending & 0.1 & 0.1 & -0.2 & -2.2 & -0.6 & -0.1 & -0.1 \\
\hline Primary balance (deficit -) & 7.8 & -2.7 & -3.6 & 0.1 & 1.6 & 9.1 & 1.9 \\
\hline Overall balance (deficit -) & 7.6 & -3.0 & -3.8 & -0.4 & 0.9 & 8.5 & 1.4 \\
\hline \multicolumn{8}{|l|}{ Memorandum item: } \\
\hline GDP (fiscal year; in millions of pula) & 33,152 & 35,467 & 38,532 & 41,805 & 47,210 & 54,713 & 60,978 \\
\hline
\end{tabular}

Sources: Ministry of Finance and Development Planning; and IMF staff estimates.

1/ Fiscal year beginning April 1.

2/ Trade and excise taxes are received from the revenue pool of the Southern African Customs Union. 
Table 15. Botswana: Components of Central Government Revenue, 2000/01-2006/07 1/

(In millions of pula)

\begin{tabular}{|c|c|c|c|c|c|c|c|}
\hline & $2000 / 01$ & $2001 / 02$ & $2002 / 03$ & $\begin{array}{r}2003 / 04 \\
\text { Rev. }\end{array}$ & $\begin{array}{r}2004 / 05 \\
\text { Rev. }\end{array}$ & $\begin{array}{r}2005 / 06 \\
\text { Prel. } \\
\end{array}$ & $\begin{array}{r}2006 / 07 \\
\text { Bud. } \\
\end{array}$ \\
\hline Tax revenue & 12,078 & 10,582 & 12,259 & 14,146 & 16,245 & 20,124 & 21,916 \\
\hline Mineral revenue & 8,368 & 6,996 & 7,503 & 8,163 & 8,682 & 11,045 & 11,389 \\
\hline Trade and excise taxes $2 /$ & 2,188 & 1,732 & 1,569 & 2,246 & 3,227 & 3,930 & 5,300 \\
\hline General sales tax & 524 & 520 & 1,255 & 1,573 & 2,116 & 1,978 & 2,118 \\
\hline Nonmineral income tax & 925 & 1,249 & 1,840 & 2,079 & 2,082 & 2,994 & 2,920 \\
\hline Export duties & 0 & 0 & 0 & 0 & 0 & 0 & 0 \\
\hline Taxes on property & 16 & 16 & 18 & 12 & 13 & 13 & 36 \\
\hline Motor vehicle tax & 40 & 51 & 55 & 62 & 105 & 127 & 124 \\
\hline Business and professional licenses & 14 & 16 & 18 & 9 & 17 & 19 & 16 \\
\hline Airport tax & 2 & 3 & 2 & 3 & 3 & 18 & 13 \\
\hline Nontax revenue & 1,908 & 1,960 & 1,896 & 1,911 & 1,226 & 2,121 & 1,826 \\
\hline Interest & 205 & 189 & 227 & 208 & -97 & 78 & 36 \\
\hline Property income & 1,195 & 1,170 & 1,064 & 969 & 433 & 912 & 704 \\
\hline Fees, charges, and reimbursements & 508 & 601 & 605 & 733 & 891 & 1,130 & 1,086 \\
\hline Grants & 65 & 59 & 84 & 61 & 348 & 290 & 363 \\
\hline Recurrent & $\ldots$ & $\ldots$ & 0 & 0 & 0 & 0 & 0 \\
\hline Development & 65 & 59 & 84 & 61 & 348 & 290 & 363 \\
\hline \multirow[t]{2}{*}{ Total revenue and grants } & 14,050 & 12,601 & 14,240 & 16,118 & 17,819 & 22,535 & 24,105 \\
\hline & \multicolumn{7}{|c|}{ (In percent of GDP) } \\
\hline Tax revenue & 36.4 & 29.8 & 31.8 & 33.8 & 34.4 & 36.8 & 35.9 \\
\hline Mineral revenue & 25.2 & 19.7 & 19.5 & 19.5 & 18.4 & 20.2 & 18.7 \\
\hline Trade and excise taxes 2/ & 6.6 & 4.9 & 4.1 & 5.4 & 6.8 & 7.2 & 8.7 \\
\hline General sales tax & 1.6 & 1.5 & 3.3 & 3.8 & 4.5 & 3.6 & 3.5 \\
\hline Nonmineral income tax & 2.8 & 3.5 & 4.8 & 5.0 & 4.4 & 5.5 & 4.8 \\
\hline Export duties & 0.0 & 0.0 & 0.0 & 0.0 & 0.0 & 0.0 & 0.0 \\
\hline Taxes on property & 0.0 & 0.0 & 0.0 & 0.0 & 0.0 & 0.0 & 0.1 \\
\hline Motor vehicle tax & 0.1 & 0.1 & 0.1 & 0.1 & 0.2 & 0.2 & 0.2 \\
\hline Business and professional licenses & 0.0 & 0.0 & 0.0 & 0.0 & 0.0 & 0.0 & 0.0 \\
\hline Airport tax & 0.0 & 0.0 & 0.0 & 0.0 & 0.0 & 0.0 & 0.0 \\
\hline Nontax revenue & 5.8 & 5.5 & 4.9 & 4.6 & 2.6 & 3.9 & 3.0 \\
\hline Interest & 0.6 & 0.5 & 0.6 & 0.5 & -0.2 & 0.1 & 0.1 \\
\hline Property income & 3.6 & 3.3 & 2.8 & 2.3 & 0.9 & 1.7 & 1.2 \\
\hline Fees, charges, and reimbursements & 1.5 & 1.7 & 1.6 & 1.8 & 1.9 & 2.1 & 1.8 \\
\hline Grants & 0.2 & 0.2 & 0.2 & 0.1 & 0.7 & 0.5 & 0.6 \\
\hline Recurrent & $\ldots$ & $\ldots$ & 0.0 & 0.0 & 0.0 & 0.0 & 0.0 \\
\hline Development & 0.2 & 0.2 & 0.2 & 0.1 & 0.7 & 0.5 & 0.6 \\
\hline Total revenue and grants & 42.4 & 35.5 & 37.0 & 38.6 & 37.7 & 41.2 & 39.5 \\
\hline \multicolumn{8}{|l|}{ Memorandum item: } \\
\hline GDP (fiscal year; in millions of pula) & 33,152 & 35,467 & 38,532 & 41,805 & 47,210 & 54,713 & 60,978 \\
\hline
\end{tabular}

Source: Ministry of Finance and Development Planning; and IMF staff estimates.

1/ Fiscal year beginning April 1.

2/ Trade and excise taxes are received from the revenue pool of the Southern African Customs Union. 
Table 16. Botswana: Economic Classification of Central Government Expenditure, 2000/01-2006/07 1/

\begin{tabular}{|c|c|c|c|c|c|c|c|}
\hline & $2000 / 01$ & $2001 / 02$ & $2002 / 03$ & $\begin{array}{r}2003 / 04 \\
\text { Rev. } \\
\end{array}$ & $\begin{array}{r}2004 / 05 \\
\text { Rev. }\end{array}$ & $\begin{array}{r}2005 / 06 \\
\text { Prel. } \\
\end{array}$ & $\begin{array}{r}2006 / 07 \\
\text { Bud. }\end{array}$ \\
\hline & \multicolumn{5}{|c|}{ (In millions of pula) } & & \\
\hline Total expenditure and net lending & 11,536 & 13,671 & 15,710 & 16,275 & 17,383 & 17,881 & 23,223 \\
\hline Current expenditure & 8,383 & 9,935 & 11,581 & 12,934 & 13,765 & 14,086 & 17,234 \\
\hline Expenditure on goods and services & 8,300 & 9,841 & 11,500 & 12,742 & 13,451 & 13,768 & 16,957 \\
\hline Wages and salaries & 2,743 & 3,446 & 3,947 & 4,142 & 5,129 & 5,248 & 5,998 \\
\hline Other purchases of goods and services 2/ & 5,557 & 6,394 & 7,553 & 8,600 & 8,322 & 8,520 & 10,959 \\
\hline Interest payments & 83 & 94 & 81 & 193 & 315 & 317 & 278 \\
\hline Capital expenditure & 3,135 & 3,698 & 4,200 & 4,256 & 3,910 & 3,851 & 6,035 \\
\hline Net lending & 19 & 38 & -71 & -916 & -293 & -56 & -47 \\
\hline Gross lending & 120 & 150 & 40 & 0 & 0 & 0 & 0 \\
\hline \multirow[t]{2}{*}{ Repayment } & -101 & -112 & -121 & -916 & -293 & -124 & -47 \\
\hline & \multicolumn{7}{|c|}{ (In percent of GDP) } \\
\hline Total expenditure and net lending & 34.8 & 38.5 & 40.8 & 38.9 & 36.8 & 32.7 & 38.1 \\
\hline Current expenditure & 25.3 & 28.0 & 30.1 & 30.9 & 29.2 & 25.7 & 28.3 \\
\hline Expenditure on goods and services & 25.0 & 27.7 & 29.8 & 30.5 & 28.5 & 25.2 & 27.8 \\
\hline Wages and salaries & 8.3 & 9.7 & 10.2 & 9.9 & 10.9 & 9.6 & 9.8 \\
\hline Other purchases of goods and services $2 /$ & 16.8 & 18.0 & 19.6 & 20.6 & 17.6 & 15.6 & 18.0 \\
\hline Interest payments & 0.3 & 0.3 & 0.2 & 0.5 & 0.7 & 0.6 & 0.5 \\
\hline Capital expenditure & 9.5 & 10.4 & 10.9 & 10.2 & 8.3 & 7.0 & 9.9 \\
\hline Net lending & 0.1 & 0.1 & -0.2 & -2.2 & -0.6 & -0.1 & -0.1 \\
\hline Gross lending & 0.4 & 0.4 & 0.1 & 0.0 & 0.0 & 0.0 & 0.0 \\
\hline Repayment & -0.3 & -0.3 & -0.3 & -2.2 & -0.6 & -0.2 & -0.1 \\
\hline \multicolumn{8}{|l|}{ Memorandum item: } \\
\hline GDP (fiscal year; in millions of pula) & 33,152 & 35,467 & 38,532 & 41,805 & 47,210 & 54,713 & 60,978 \\
\hline
\end{tabular}

Sources: Ministry of Finance and Development Planning; and IMF staff estimates.

1/ Fiscal year beginning April 1.

2/ Includes transfers. 
Table 17. Botswana: Functional Classification of Central Government Expenditure, 2000/01-2006/07 1/

\begin{tabular}{|c|c|c|c|c|c|c|c|}
\hline & $2000 / 01$ & $2001 / 02$ & $2002 / 03$ & $\begin{array}{r}2003 / 04 \\
\text { Rev. }\end{array}$ & $\begin{array}{r}2004 / 05 \\
\text { Rev. }\end{array}$ & $\begin{array}{r}2005 / 06 \\
\text { Prel. } \\
\end{array}$ & $\begin{array}{r}2006 / 07 \\
\text { Bud. }\end{array}$ \\
\hline & \multicolumn{7}{|c|}{ (In millions of pula) } \\
\hline General public services & 2,298 & 2,400 & 2,968 & 3,480 & 3,213 & 4,017 & 4,731 \\
\hline General administration & 1,612 & 1,771 & 2,195 & 2,672 & 2,292 & 3,087 & 3,574 \\
\hline Public order and safety & 686 & 629 & 773 & 809 & 921 & 930 & 1,157 \\
\hline Defense & 998 & 1,305 & 1,451 & 1,503 & 1,464 & 1,556 & 1,686 \\
\hline Social services & 5,033 & 5,876 & 6,889 & 7,556 & 7,978 & 9,662 & 10,976 \\
\hline Education & 2,872 & 3,409 & 3,597 & 3,932 & 4,190 & 4,927 & 5,748 \\
\hline Health & 630 & 803 & 1,103 & 1,634 & 2,076 & 2,494 & 2,536 \\
\hline Food and social welfare programs & 424 & 463 & 350 & 384 & 116 & 215 & 164 \\
\hline Housing and urban and regional development & 762 & 827 & 1,218 & 1,045 & 993 & 1,342 & 1,673 \\
\hline Other community and social services & 345 & 373 & 621 & 561 & 603 & 685 & 855 \\
\hline Economic services & 2,107 & 2,751 & 3,134 & 2,780 & 2,924 & 3,190 & 3,524 \\
\hline Agriculture, forestry, and fishing & 482 & 570 & 688 & 642 & 540 & 672 & 674 \\
\hline Mining & 75 & 394 & 101 & 92 & 116 & 135 & 169 \\
\hline Electricity and water supply & 576 & 668 & 994 & 883 & 1,035 & 1,111 & 1,151 \\
\hline Roads, other transport, and communications & 580 & 695 & 742 & 511 & 524 & 547 & 726 \\
\hline Commerce, industry, and other & 330 & 424 & 609 & 652 & 708 & 725 & 804 \\
\hline Unallocated expenditure and adjustments & 19 & 36 & -373 & -916 & -293 & $-2,365$ & 188 \\
\hline \multirow[t]{2}{*}{ Total } & 11,536 & 13,671 & 15,710 & 16,275 & 17,383 & 17,881 & 23,223 \\
\hline & \multicolumn{7}{|c|}{ (In percent of GDP) } \\
\hline General public services & 6.9 & 6.8 & 7.7 & 8.3 & 6.8 & 7.3 & 7.8 \\
\hline General administration & 4.9 & 5.0 & 5.7 & 6.4 & 4.9 & 5.6 & 5.9 \\
\hline Public order and safety & 2.1 & 1.8 & 2.0 & 1.9 & 2.0 & 1.7 & 1.9 \\
\hline Defense & 3.0 & 3.7 & 3.8 & 3.6 & 3.1 & 2.8 & 2.8 \\
\hline Social services & 15.2 & 16.6 & 17.9 & 18.1 & 16.9 & 17.7 & 18.0 \\
\hline Education & 8.7 & 9.6 & 9.3 & 9.4 & 8.9 & 9.0 & 9.4 \\
\hline Health & 1.9 & 2.3 & 2.9 & 3.9 & 4.4 & 4.6 & 4.2 \\
\hline Food and social welfare programs & 1.3 & 1.3 & 0.9 & 0.9 & 0.2 & 0.4 & 0.3 \\
\hline Housing and urban and regional development & 2.3 & 2.3 & 3.2 & 2.5 & 2.1 & 2.5 & 2.7 \\
\hline Other community and social services & 1.0 & 1.1 & 1.6 & 1.3 & 1.3 & 1.3 & 1.4 \\
\hline Economic services & 6.4 & 7.8 & 8.1 & 6.7 & 6.2 & 5.8 & 5.8 \\
\hline Agriculture, forestry, and fishing & 1.5 & 1.6 & 1.8 & 1.5 & 1.1 & 1.2 & 1.1 \\
\hline Mining & 0.2 & 1.1 & 0.3 & 0.2 & 0.2 & 0.2 & 0.3 \\
\hline Electricity and water supply & 1.7 & 1.9 & 2.6 & 2.1 & 2.2 & 2.0 & 1.9 \\
\hline Roads, other transport, and communications & 1.8 & 2.0 & 1.9 & 1.2 & 1.1 & 1.0 & 1.2 \\
\hline Commerce, industry, and other & 1.0 & 1.2 & 1.6 & 1.6 & 1.5 & 1.3 & 1.3 \\
\hline Unallocated expenditure and adjustments & 0.1 & 0.1 & -1.0 & -2.2 & -0.6 & -4.3 & 0.3 \\
\hline Total & 34.8 & 38.5 & 40.8 & 38.9 & 36.8 & 32.7 & 38.1 \\
\hline \multicolumn{8}{|l|}{ Memorandum item: } \\
\hline GDP (fiscal year; in millions of pula) & 33,152 & 35,467 & 38,532 & 41,805 & 47,210 & 54,713 & 60,978 \\
\hline
\end{tabular}

Source: Ministry of Finance and Development Planning; and IMF staff estimates.

1/ Fiscal year beginning April 1. 
Table 18. Botswana: Summary of Operations of Nonfinancial Public Enterprises, 2000-2005 1/

\begin{tabular}{|c|c|c|c|c|c|c|}
\hline & 2000 & 2001 & 2002 & 2003 & 2004 & 2005 \\
\hline & \multicolumn{6}{|c|}{ (In millions of pula) } \\
\hline Operating revenue & 2,082 & 2,300 & 2,342 & 2,579 & 2,271 & 1,702 \\
\hline \multicolumn{7}{|l|}{ Subsidies and transfers } \\
\hline Net profit/loss & 305 & 386 & 272 & 317 & 607 & 377 \\
\hline Long-term debt outstanding & 2,036 & 2,102 & 2,013 & 1,833 & 1,800 & 920 \\
\hline Equity & 4,599 & 4,991 & 5,321 & 5,592 & 5,821 & 3,837 \\
\hline Capital employed & 5,853 & 7,449 & 7,783 & 7,944 & 8,604 & 4,679 \\
\hline \multirow[t]{2}{*}{ Fixed assets } & 4,776 & 5,921 & 6,087 & 6,391 & 6,354 & 4,050 \\
\hline & \multicolumn{6}{|c|}{ (In percent, period average, unless otherwise indicated) } \\
\hline Return on capital employed & 3.3 & 12.8 & 3.1 & -6.9 & 5.7 & 10.1 \\
\hline Return on equity & 3.5 & 14.1 & 3.8 & -8.6 & 10.7 & 12.7 \\
\hline Net profit-to-sales ratio & 17.6 & 23.6 & 11.8 & 7.6 & 21.5 & 57.1 \\
\hline Debt-to-equity ratio & 0.4 & 0.4 & 0.4 & 0.4 & 0.5 & 0.4 \\
\hline \multicolumn{7}{|l|}{ Memorandum item: } \\
\hline Operating revenue (in percent of GDP) & 8.3 & 6.6 & 6.6 & 6.5 & 5.3 & 3.5 \\
\hline
\end{tabular}

Source: Bank of Botswana.

1/ Includes the Botswana Agricultural Marketing Board, the Botswana Livestock Development Corporation, the Botswana Housing Corporation, the Botswana Meat Commission, the Botswana Power Corporation, the Botswana Telecommunications Corporation, and the Botswana Water Utilities Corporation. 
Table 19. Botswana: Monetary Survey, 2003-2006

\begin{tabular}{|c|c|c|c|c|c|c|c|}
\hline & \multirow[t]{2}{*}{2003} & \multirow[t]{2}{*}{2004} & \multicolumn{4}{|c|}{2005} & \multirow{2}{*}{$\begin{array}{r}2006 \\
\text { Mar }\end{array}$} \\
\hline & & & Mar & Jun & Sep & Dec & \\
\hline & \multicolumn{7}{|c|}{ (In millions of pula; end of period) } \\
\hline Net foreign assets & 25,238 & 25,519 & 29,160 & 33,510 & 34,883 & 35,916 & 36,785 \\
\hline Bank of Botswana & 23,887 & 24,368 & 27,612 & 32,285 & 33,681 & 34,751 & 36,709 \\
\hline Commercial banks & 1,351 & 1,152 & 1,548 & 1,224 & 1,202 & 1,166 & 76 \\
\hline Net domestic assets & $-14,261$ & $-12,788$ & $-15,910$ & $-20,405$ & $-20,349$ & $-21,956$ & $-17,975$ \\
\hline Net domestic credit & $-3,460$ & $-1,264$ & $-2,289$ & $-2,179$ & $-3,655$ & $-3,556$ & $-4,505$ \\
\hline Net claims on the government & $-10,662$ & $-9,705$ & $-10,731$ & $-10,874$ & $-12,621$ & $-12,613$ & $-13,839$ \\
\hline Bank of Botswana & $-10,514$ & $-9,272$ & $-10,279$ & $-10,489$ & $-12,307$ & $-12,448$ & $-13,666$ \\
\hline Commercial banks & -148 & -433 & -452 & -385 & -314 & -165 & -174 \\
\hline Claims on nongovernment & 7,202 & 8,441 & 8,442 & 8,695 & 8,967 & 9,057 & 9,334 \\
\hline Claims on parastatals & 381 & 433 & 392 & 365 & 386 & 318 & 286 \\
\hline Claims on the private sector & 6,821 & 8,007 & 8,050 & 8,330 & 8,581 & 8,739 & 9,048 \\
\hline Other items (net) & $-10,801$ & $-11,524$ & $-13,621$ & $-18,226$ & $-16,694$ & $-18,400$ & $-13,469$ \\
\hline \multicolumn{8}{|l|}{ Of which } \\
\hline Valuation adjustment 1/ & $-8,131$ & 869 & $\ldots$ & $\ldots$ & $\ldots$ & $-6,939$ & \\
\hline Money plus quasi-money (M2) & 10,977 & 12,731 & 13,250 & 13,105 & 14,534 & 13,960 & 18,811 \\
\hline Money (M1) & 2,822 & 3,626 & 3,550 & 3,878 & 4,390 & 3,842 & 3,744 \\
\hline Quasi money 2/ & 8,155 & 9,105 & 9,700 & 9,227 & 10,144 & 10,118 & 15,067 \\
\hline \multicolumn{8}{|l|}{ Memorandum items: } \\
\hline Broad money (M3) & 17,428 & 19,395 & 20,905 & 21,356 & 22,047 & 22,346 & 22,358 \\
\hline \multicolumn{8}{|l|}{ Of which } \\
\hline Bank of Botswana certificates 3/ & 6,451 & 6,664 & 7,655 & 8,251 & 7,513 & 8,387 & 3,547 \\
\hline Broad money (M4) & 18,946 & 20,802 & 22,597 & 23,113 & 24,523 & 25,279 & 24,886 \\
\hline \multicolumn{8}{|l|}{ Of which } \\
\hline \multirow[t]{2}{*}{ Foreign currency accounts } & 1,518 & 1,406 & 1,692 & 1,757 & 2,476 & 2,932 & 2,528 \\
\hline & \multicolumn{7}{|c|}{ (Twelve-month percentage change) } \\
\hline Net foreign assets 4 / & -19.2 & 1.1 & 5.4 & 29.4 & 29.8 & 40.7 & 26.1 \\
\hline Net domestic assets & 34.4 & 10.3 & 1.8 & -53.5 & -41.1 & -71.7 & -13.0 \\
\hline Net domestic credit & 64.9 & 63.5 & 51.9 & 13.4 & -41.9 & -181.3 & -96.8 \\
\hline \multicolumn{8}{|l|}{ Of which } \\
\hline Claims on the government (net) & 35.3 & 9.0 & 11.6 & -5.8 & -16.8 & -30.0 & -29.0 \\
\hline Claims on the private sector & 10.7 & 17.4 & 15.1 & 12.5 & 9.7 & 9.1 & 12.4 \\
\hline Money plus quasi-money (M2) & 15.5 & 16.0 & 15.5 & 4.0 & 16.6 & 9.7 & 42.0 \\
\hline Money (M1) & 11.8 & 28.5 & 16.8 & 10.1 & 29.5 & 6.0 & 5.4 \\
\hline Broad money (M3) & 13.2 & 11.3 & 18.5 & 10.9 & 14.2 & 15.2 & 6.9 \\
\hline Broad money (M4) & 11.9 & 9.8 & 18.5 & 10.5 & 17.5 & 21.5 & 10.1 \\
\hline
\end{tabular}

Source: Bank of Botswana.

1/ Equivalent to the revaluation profit (loss) for the year reported on the books of the Bank of Botswana.

2/ Includes private deposits at the Bank of Botswana but excludes holdings of Bank of Botswana certificates.

3/ Excludes the Bank of Botswana Certificates held by commercial banks on their own accounts.

4/ Excludes the effect of foreign assets valuation adjustments. 
Table 20. Botswana: Summary Accounts of Bank of Botswana, 2003-2006

(In millions of pula; end of period)

\begin{tabular}{|c|c|c|c|c|c|c|c|}
\hline & \multirow[t]{2}{*}{2003} & \multirow[t]{2}{*}{2004} & \multicolumn{4}{|c|}{2005} & \multirow{2}{*}{$\begin{array}{r}2006 \\
\text { Mar }\end{array}$} \\
\hline & & & Mar & Jun & Sep & Dec & \\
\hline Foreign assets & 23,887 & 24,368 & 27,612 & 32,285 & 33,681 & 34,751 & 36,709 \\
\hline Pula fund & 19,246 & 20,013 & 21,750 & 25,942 & 26,200 & 24,867 & 25,660 \\
\hline Liquidity portfolio & 4,055 & 3,827 & 5,315 & 5,620 & 6,941 & 9,404 & 10,536 \\
\hline Matched assets/liability portfolio & 166 & 163 & 167 & 298 & 146 & 141 & 174 \\
\hline Fund accounts & 421 & 365 & 381 & 425 & 394 & 339 & 339 \\
\hline Holding of SDRs & 221 & 229 & 242 & 280 & 278 & 280 & 283 \\
\hline Reserve position & 197 & 134 & 137 & 145 & 116 & 58 & 56 \\
\hline Valuation Adjustment & 3 & 2 & 2 & 0 & 0 & 0 & 0 \\
\hline Loans and advances to financial institutions & 0 & 0 & 0 & 0 & 0 & 0 & 0 \\
\hline Fixed assets & 127 & 130 & 132 & 134 & 134 & 128 & 128 \\
\hline Other assets & -5 & -5 & -5 & 1 & 0 & 1 & 1 \\
\hline Assets $=$ liabilities & 24,009 & 24,493 & 27,739 & 32,420 & 33,815 & 34,879 & 36,838 \\
\hline Reserve money & 1,338 & 1,262 & 1,739 & 1,334 & 1,523 & 1,388 & 1,611 \\
\hline Currency in circulation & 818 & 911 & 865 & 874 & 928 & 935 & 851 \\
\hline Currency outside banks & 533 & 637 & 634 & 688 & 730 & 632 & 669 \\
\hline Pula currency in banks & 285 & 274 & 231 & 185 & 199 & 303 & 182 \\
\hline Bankers' deposits & 520 & 351 & 874 & 460 & 595 & 453 & 761 \\
\hline Private sector time deposits & 231 & 852 & 727 & 286 & 535 & 526 & 635 \\
\hline Bank of Botswana certificates outstanding & 8,739 & 9,649 & 10,532 & 12,195 & 11,480 & 12,416 & 13,176 \\
\hline Bankers & 6,583 & 6,453 & 7,660 & 8,008 & 8,595 & 8,541 & 10,172 \\
\hline Others & 2,780 & 3,023 & 3,317 & 3,416 & 3,378 & 3,742 & 1,657 \\
\hline Government deposits & 10,514 & 9,272 & 10,279 & 10,489 & 12,307 & 12,448 & 13,666 \\
\hline Capital and reserves & 2,730 & 3,026 & 4,073 & 7,683 & 7,495 & 7,168 & 7,243 \\
\hline Paid-up capital & 25 & 25 & 25 & 25 & 25 & 25 & 25 \\
\hline General reserve & 1,600 & 1,600 & 1,600 & 1,600 & 1,600 & 1,600 & 1,600 \\
\hline Revaluation reserve & 1,105 & 1,401 & 2,448 & 6,058 & 5,870 & 5,543 & 5,618 \\
\hline Other liabilities & 457 & 432 & 389 & 433 & 475 & 933 & 508 \\
\hline
\end{tabular}

Source: Bank of Botswana. 
Table 21. Botswana: Summary Accounts of Commercial Banks, 2003-2006 (In millions of pula; end of period)

\begin{tabular}{|c|c|c|c|c|c|c|c|}
\hline & \multirow[t]{2}{*}{2003} & \multirow[t]{2}{*}{2004} & \multicolumn{4}{|c|}{2005} & \multirow{2}{*}{$\begin{array}{r}2006 \\
\text { Mar }\end{array}$} \\
\hline & & & Mar & Jun & Sep & Dec & \\
\hline Commercial bank reserves & 397 & 470 & 837 & 325 & 818 & 383 & 350 \\
\hline Cash & 285 & 274 & 231 & 185 & 199 & 303 & 182 \\
\hline Balances at Bank of Botswana & 111 & 196 & 606 & 140 & 619 & 80 & 168 \\
\hline Foreign assets & 1,772 & 1,485 & 1,943 & 1,969 & 2,875 & 2,843 & 2,092 \\
\hline Claims on monetary authorities & 2,229 & 2,749 & 2,785 & 3,916 & 3,913 & 4,216 & 9,614 \\
\hline Credit to domestic economy & 7,202 & 8,441 & 8,442 & 8,695 & 8,967 & 9,057 & 9,334 \\
\hline Claims on local governments & 0 & 0 & 0 & 0 & 0 & 0 & 0 \\
\hline Claims on parastatals & 381 & 433 & 392 & 365 & 386 & 318 & 286 \\
\hline $\begin{array}{l}\text { Claims on private sector } \\
\text { Of which }\end{array}$ & 6,821 & 8,007 & 8,050 & 8,330 & 8,581 & 8,739 & 9,048 \\
\hline Claims on households & 3,910 & 4,948 & 4,967 & 5,073 & 5,214 & 5,320 & 5,453 \\
\hline Other assets & 1,568 & 1,903 & 1,767 & 1,770 & 1,880 & 1,468 & 2,549 \\
\hline Fixed assets & 205 & 205 & 202 & 218 & 196 & 198 & 190 \\
\hline Others $1 /$ & 1,363 & 1,697 & 1,564 & 1,552 & 1,684 & 1,270 & 2,359 \\
\hline Assets $=$ liabilities & 13,168 & 15,048 & 15,773 & 16,675 & 18,452 & 17,967 & 23,940 \\
\hline Demand deposits of the public & 2,290 & 2,989 & 2,917 & 3,189 & 3,661 & 3,210 & 3,075 \\
\hline Time and savings deposits & 7,924 & 8,253 & 8,973 & 8,941 & 9,609 & 9,592 & 14,432 \\
\hline Liabilities to other banks & 421 & 333 & 395 & 744 & 1,673 & 1,677 & 2,016 \\
\hline Liabilities to Bank of Botswana & 1 & 4 & 3 & 18 & 0 & 105 & 5 \\
\hline Government deposits & 148 & 433 & 452 & 385 & 314 & 165 & 174 \\
\hline Capital and reserves & 1,346 & 1,395 & 1,492 & 1,577 & 1,516 & 1,471 & 1,638 \\
\hline Other liabilities & 1,038 & 1,640 & 1,542 & 1,821 & 1,680 & 1,746 & 2,601 \\
\hline
\end{tabular}

Source: Bank of Botswana.

1/ Comprises other investments: balances due from domestic banks, bills purchased and discounted, Bank of Botswana Certificates, and other unclassified assets. 
Table 22. Botswana: Selected Financial Ratios and Aggregates of Commercial Banks, 2001-2006 (In millions of pula, unless otherwise indicated; end of period)

\begin{tabular}{|c|c|c|c|c|c|c|c|c|}
\hline & \multirow[t]{2}{*}{2001} & \multirow[t]{2}{*}{2002} & \multirow[t]{2}{*}{2003} & \multirow[t]{2}{*}{2004} & \multirow[t]{2}{*}{2005} & \multicolumn{3}{|c|}{2006} \\
\hline & & & & & & Jan & Feb & Mar \\
\hline \multicolumn{9}{|l|}{ Liquid assets $1 /$} \\
\hline Required & 676 & 812 & 899 & 1,006 & 1,108 & 984 & 996 & 1,094 \\
\hline Actual & 2,613 & 2,188 & 2,547 & 3,237 & 4,768 & 6,061 & 5,667 & 10,530 \\
\hline Excess & 1,937 & 1,376 & 1,649 & 2,231 & 3,660 & 5,077 & 4,671 & 9,436 \\
\hline Ratio of actual to required & 3.9 & 2.7 & 2.8 & 3.2 & 4.3 & 6.2 & 5.7 & 9.6 \\
\hline \multicolumn{9}{|l|}{ Primary reserves $2 /$} \\
\hline Required & 220 & 264 & 292 & 327 & 360 & 320 & 498 & 547 \\
\hline Actual & 263 & 286 & 403 & 523 & 440 & 507 & 577 & 715 \\
\hline Excess & 43 & 22 & 111 & 196 & 80 & 187 & 79 & 168 \\
\hline Ratio of actual to required & 1.2 & 1.1 & 1.4 & 1.6 & 1.2 & 1.6 & 1.2 & 1.3 \\
\hline Deposit liabilities & 9,233 & 8,983 & 10,574 & 11,876 & 13,227 & 13,606 & 13,931 & 18,128 \\
\hline Credit & 5,462 & 6,628 & 7,289 & 8,460 & 9,080 & 9,105 & 9,183 & 9,367 \\
\hline Ratio of credit to deposit liabilities & 0.6 & 0.7 & 0.7 & 0.7 & 0.7 & 0.7 & 0.7 & 0.5 \\
\hline
\end{tabular}

Source: Bank of Botswana.

1/ Required liquid assets are 10 percent of commercial banks' daily average deposit balances. Eligible liquid assets include cash, current account balance with the Bank of Botswana $(\mathrm{BoB})$ in excess of the primary required reserve, balances due from domestic banks, foreign notes and coins, BoB certificates, and private sector bills eligible for discount at the BoB.

2/ Primary required reserves, consisting of current account balances with the $\mathrm{BoB}$, are 3.25 percent of average daily deposit balances. 
Table 23. Botswana: Selected Interest Rates, 2001-2006

(In percent; end of period)

\begin{tabular}{|c|c|c|c|c|c|c|}
\hline & 2001 & 2002 & 2003 & 2004 & 2005 & $\begin{array}{r}2006 \\
\text { Mar }\end{array}$ \\
\hline \multicolumn{7}{|l|}{ Bank of Botswana } \\
\hline Lending rate (bank rate) & 14.3 & 15.3 & 14.3 & 14.3 & 14.5 & 15.0 \\
\hline \multicolumn{7}{|l|}{ Public Debt Service Fund 1/ } \\
\hline Financial parastatals & 13.8 & 13.8 & 13.8 & $\ldots$ & $\ldots$ & $\ldots$ \\
\hline Nonfinancial parastatals & 16.3 & 16.3 & 16.3 & $\ldots$ & $\ldots$ & $\ldots$ \\
\hline \multicolumn{7}{|l|}{ Commercial banks } \\
\hline \multicolumn{7}{|l|}{ Deposit rates } \\
\hline Savings accounts & 8.4 & 8.4 & 7.7 & 7.5 & 6.6 & 6.8 \\
\hline Call deposits & 9.5 & 10.0 & 9.6 & 9.1 & 8.6 & 8.6 \\
\hline 31 days' notice & 9.3 & 10.0 & 9.6 & 9.3 & 8.6 & 8.7 \\
\hline 88 days' notice & 9.8 & 10.2 & 9.5 & 9.9 & 9.3 & 8.7 \\
\hline \multicolumn{7}{|l|}{ Fixed deposits } \\
\hline 6 months & 10.4 & 10.8 & 10.5 & 10.2 & 9.7 & 9.5 \\
\hline 12 months & 10.6 & 11.0 & 10.3 & 10.5 & 10.1 & 9.5 \\
\hline Prime lending rate & 15.8 & 16.8 & 15.8 & 15.8 & 16.0 & 16.5 \\
\hline \multicolumn{7}{|l|}{ Botswana Building Society } \\
\hline \multicolumn{7}{|l|}{ Deposit rates } \\
\hline Indefinite period paid-up shares & 10.0 & 10.0 & 12.0 & 10.5 & 10.5 & 10.5 \\
\hline Subscription shares & 8.5 & 8.5 & 8.5 & 8.5 & 7.5 & 7.5 \\
\hline \multicolumn{7}{|l|}{ Fixed-time deposits } \\
\hline Ordinary savings accounts & 2.5 & 2.5 & 3.0 & 3.0 & 3.5 & 3.5 \\
\hline Special savings accounts & 7.5 & 7.5 & 10.0 & 8.6 & 10.0 & 10.0 \\
\hline \multicolumn{7}{|l|}{ Lending rates } \\
\hline Mortgage loans 2/ & 14.5 & 14.5 & 15.0 & 15.5 & 16.0 & 16.0 \\
\hline Short-term loans 3/ & 17.0 & 17.0 & 17.0 & 17.0 & 17.5 & 17.5 \\
\hline \multicolumn{7}{|l|}{ Botswana Savings Bank } \\
\hline Ordinary savings accounts & 3.5 & 3.5 & 4.0 & 4.0 & 4.0 & 4.0 \\
\hline Special savings accounts & 7.5 & 7.5 & 8.0 & 8.0 & 8.0 & 8.0 \\
\hline
\end{tabular}

Source: Bank of Botswana.

1/ In 1991, a two-tier rate structure was introduced, with the lower rate applying to financial parastatals and the higher rate to nonfinancial parastatals.

2/ Loans over P 50,000 are charged an additional percentage point.

3 / Interest rates on short-term loans vary according to the security offered by the borrower. 
Table 24. Botswana: Distribution of Commercial Bank Credit by Economic Activity, 2001-2006

\begin{tabular}{|c|c|c|c|c|c|c|}
\hline & 2001 & 2002 & 2003 & 2004 & 2005 & $\begin{array}{r}2006 \\
\text { Mar }\end{array}$ \\
\hline \multicolumn{7}{|c|}{ (In millions of pula; end of period) } \\
\hline Agriculture & 51 & 44 & 54 & 120 & 129 & 102 \\
\hline Mining & 39 & 128 & 116 & 40 & 19 & 55 \\
\hline Manufacturing & 264 & 330 & 389 & 356 & 334 & 348 \\
\hline Construction & 131 & 209 & 222 & 241 & 192 & 210 \\
\hline Electricity and water & 42 & 56 & 51 & 86 & 72 & 67 \\
\hline Transport and communications & 181 & 118 & 123 & 288 & 297 & 303 \\
\hline Trade & 390 & 579 & 849 & 448 & 517 & 483 \\
\hline Business services & 801 & 984 & 982 & 1,265 & 1,509 & 1,609 \\
\hline Finance & 37 & 25 & 26 & 24 & 53 & 101 \\
\hline Other business & 98 & 133 & 187 & 273 & 299 & 318 \\
\hline Financial parastatals & 480 & 462 & 381 & 433 & 318 & 286 \\
\hline Local government & 1 & 0 & 0 & 0 & 0 & 0 \\
\hline Central government & 0 & 0 & 0 & 0 & 0 & 0 \\
\hline Households & 2,948 & 3,561 & 3,910 & 4,866 & 5,312 & 5,453 \\
\hline Total & 5,462 & 6,628 & 7,289 & 8,441 & 9,049 & 9,367 \\
\hline & \multicolumn{6}{|c|}{ (In percent of total) } \\
\hline Agriculture & 0.9 & 0.7 & 0.7 & 1.4 & 1.4 & 1.1 \\
\hline Mining & 0.7 & 1.9 & 1.6 & 0.5 & 0.2 & 0.6 \\
\hline Manufacturing & 4.8 & 5.0 & 5.3 & 4.2 & 3.7 & 3.7 \\
\hline Construction & 2.4 & 3.2 & 3.0 & 2.9 & 2.1 & 2.2 \\
\hline Electricity and water & 0.8 & 0.8 & 0.7 & 1.0 & 0.8 & 0.7 \\
\hline Transport and communications & 3.3 & 1.8 & 1.7 & 3.4 & 3.3 & 3.2 \\
\hline Trade & 7.1 & 8.7 & 11.6 & 5.3 & 5.7 & 5.2 \\
\hline Business services & 14.7 & 14.9 & 13.5 & 15.0 & 16.7 & 17.2 \\
\hline Finance & 0.7 & 0.4 & 0.4 & 0.3 & 0.6 & 1.1 \\
\hline Other business & 1.8 & 2.0 & 2.6 & 3.2 & 3.3 & 3.4 \\
\hline Financial parastatals & 8.8 & 7.0 & 5.2 & 5.1 & 3.5 & 3.1 \\
\hline Local government & 0.0 & 0.0 & 0.0 & 0.0 & 0.0 & 0.0 \\
\hline Central government & 0.0 & 0.0 & 0.0 & 0.0 & 0.0 & 0.0 \\
\hline Households & 54.0 & 53.7 & 53.6 & 57.7 & 58.7 & 58.2 \\
\hline Total & 100.0 & 100.0 & 100.0 & 100.0 & 100.0 & 100.0 \\
\hline
\end{tabular}

Source: Bank of Botswana. 
Table 25. Botswana: Sources of Commercial Bank Deposits, 2000-2006

\begin{tabular}{|c|c|c|c|c|c|c|c|}
\hline & 2000 & 2001 & 2002 & 2003 & 2004 & 2005 & $\begin{array}{r}2006 \\
\text { Mar }\end{array}$ \\
\hline & \multicolumn{7}{|c|}{ (In millions of pula; end of period) } \\
\hline Government & 470 & 669 & 602 & 1,098 & 1,063 & 465 & 513 \\
\hline Central & 106 & 61 & 58 & 148 & 433 & 165 & 174 \\
\hline Local & 364 & 609 & 544 & 950 & 630 & 299 & 338 \\
\hline Parastatals & 617 & 823 & 780 & 969 & 1,166 & 485 & 1,461 \\
\hline Private enterprises & 3,425 & 5,571 & 5,109 & 5,249 & 7,147 & 8,206 & 12,043 \\
\hline Households & 2,401 & 2,171 & 2,492 & 3,259 & 2,500 & 4,082 & 4,112 \\
\hline \multirow[t]{2}{*}{ Total } & 6,912 & 9,233 & 8,983 & 10,574 & 11,876 & 13,238 & 18,128 \\
\hline & \multicolumn{7}{|c|}{ (In percent of total) } \\
\hline Government & 6.8 & 7.2 & 6.7 & 10.4 & 8.9 & 3.5 & 2.8 \\
\hline Central & 1.5 & 0.7 & 0.6 & 1.4 & 3.6 & 1.2 & 1.0 \\
\hline Local & 5.3 & 6.6 & 6.1 & 9.0 & 5.3 & 2.3 & 1.9 \\
\hline Parastatals & 8.9 & 8.9 & 8.7 & 9.2 & 9.8 & 3.7 & 8.1 \\
\hline Private enterprises & 49.5 & 60.3 & 56.9 & 49.6 & 60.2 & 62.0 & 66.4 \\
\hline Households & 34.7 & 23.5 & 27.7 & 30.8 & 21.1 & 30.8 & 22.7 \\
\hline Total & 100.0 & 100.0 & 100.0 & 100.0 & 100.0 & 100.0 & 100.0 \\
\hline
\end{tabular}

Source: Bank of Botswana. 
Table 26. Botswana: Auctions of Bank of Botswana Certificates, 2004-06 1/

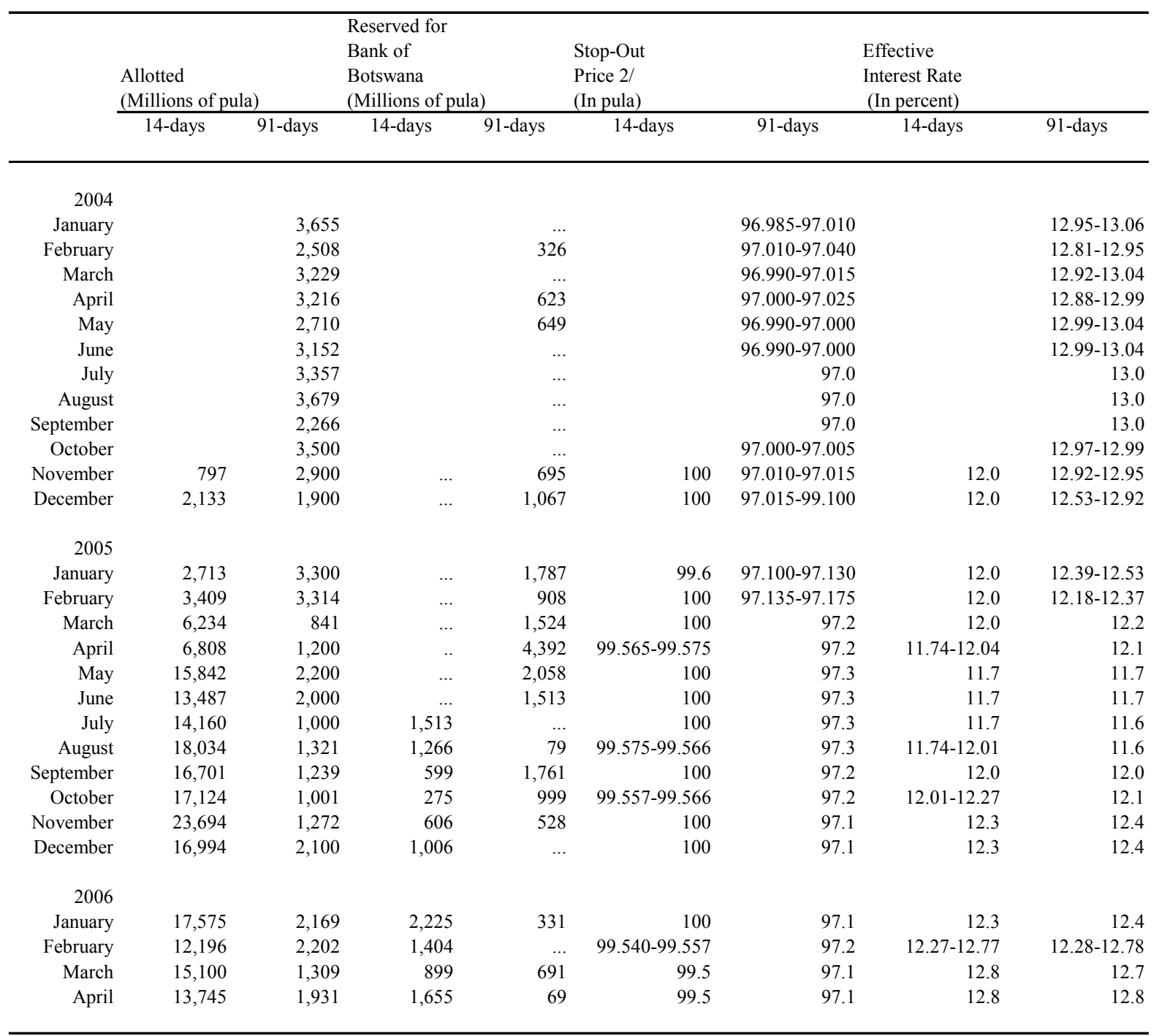

1/ In any month with more than one auction, the stop-out price and interest rates are arithmetic averages.

2/ The stop-out price is the price below which no bid for Bank of Botswana Certificates will be entertained by the Bank of Botswana. 
Table 27. Botswana: Value of Outstanding Bank of Botswana Certificates, 2004-06 1/

(In millions of pula; end of period)

\begin{tabular}{|c|c|c|c|c|}
\hline & $\begin{array}{r}\text { Commercial } \\
\text { Banks }\end{array}$ & $\begin{array}{r}\text { Other Financial } \\
\text { Institutions }\end{array}$ & $\begin{array}{r}\text { Other Private } \\
\text { Sector }\end{array}$ & Total \\
\hline \multicolumn{5}{|l|}{2004} \\
\hline January & 6,537 & 1,822 & 889 & 9,248 \\
\hline February & 5,800 & 1,996 & 983 & 8,778 \\
\hline March & 5,918 & 1,763 & 892 & 8,573 \\
\hline April & 5,992 & 1,659 & 1,461 & 9,112 \\
\hline May & 6,995 & 1,511 & 1,412 & 9,918 \\
\hline June & 6,005 & 1,422 & 1,757 & 9,184 \\
\hline July & 6,228 & 1,225 & 1,788 & 9,241 \\
\hline August & 6,543 & 1,116 & 1,795 & 9,455 \\
\hline September & 6,543 & 875 & 1,790 & 9,208 \\
\hline October & 6,541 & 972 & 1,852 & 9,365 \\
\hline November & 6,453 & 975 & 2,093 & 9,522 \\
\hline December & 6,626 & 1,008 & 2,015 & 9,649 \\
\hline \multicolumn{5}{|l|}{2005} \\
\hline January & 7,054 & 1,099 & 1,928 & 10,081 \\
\hline February & 7,660 & 1,292 & 2,048 & 10,999 \\
\hline March & 7,215 & 1,275 & 2,042 & 10,532 \\
\hline April & 8,495 & 956 & 1,440 & 10,890 \\
\hline May & 8,008 & 1,113 & 2,081 & 11,203 \\
\hline June & 8,780 & 1,312 & 2,104 & 12,195 \\
\hline July & 8,811 & 1,350 & 2,176 & 12,337 \\
\hline August & 8,595 & 1,208 & 2,600 & 12,403 \\
\hline September & 8,102 & 1,266 & 2,112 & 11,480 \\
\hline October & 8,321 & 1,319 & 2,713 & 12,353 \\
\hline November & 8,541 & 1,477 & 2,654 & 12,672 \\
\hline December & 8,674 & 1,409 & 2,334 & 12,416 \\
\hline \multicolumn{5}{|l|}{2006} \\
\hline January & 10,782 & 616 & 1,838 & 13,236 \\
\hline February & 10,172 & 636 & 2,023 & 12,831 \\
\hline March & 11,519 & 723 & 935 & 13,176 \\
\hline
\end{tabular}

Sources: Bank of Botswana.

1/ Total market value, excluding interest. 
Table 28. Botswana: Financial System Structure, 2004

\begin{tabular}{|c|c|c|c|}
\hline & $\begin{array}{r}\text { Assets } \\
\text { (In billions } \\
\text { of pula) } \\
\end{array}$ & 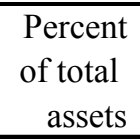 & $\begin{array}{l}\text { Percent } \\
\text { of GDP }\end{array}$ \\
\hline Total onshore financial system & 39.0 & 100.0 & 92.6 \\
\hline Banks - onshore & 15.6 & 40.0 & 37.0 \\
\hline Domestic commercial banks & $\ldots$ & $\ldots$ & $\ldots$ \\
\hline Foreign commercial banks & 14.8 & 38.1 & 35.3 \\
\hline State-owned commercial banks & $\ldots$ & $\ldots$ & $\ldots$ \\
\hline Merchant banks & 0.7 & 1.9 & 1.8 \\
\hline Institutional Investors & 10.0 & 25.7 & 23.8 \\
\hline Insurance companies $1 /$ & 0.6 & 1.6 & 1.5 \\
\hline Pension funds $2 /$ & 6.8 & 17.4 & 16.1 \\
\hline Collective investment undertaking (CIU) & 2.6 & 6.8 & 6.3 \\
\hline Other nonbank & 13.4 & 34.3 & 31.7 \\
\hline Botswana Development Corporation & 1.2 & 3.0 & 2.8 \\
\hline National Development Bank & 0.5 & 1.4 & 1.3 \\
\hline Botswana Savings Bank & 0.2 & 0.6 & 0.5 \\
\hline Botswana Building Society & 0.6 & 1.5 & 1.4 \\
\hline Leasing companies & $\ldots$ & $\ldots$ & $\ldots$ \\
\hline Securities firms & 10.9 & 27.9 & 25.8 \\
\hline Total offshore financial system & 3.4 & 100.0 & 8.1 \\
\hline Banks - offshore & 0.0 & 0.7 & 0.1 \\
\hline Insurance companies - offshore & $\ldots$ & $\ldots$ & $\ldots$ \\
\hline Other offshore NBFIs & 3.4 & 99.2 & 8.1 \\
\hline Total financial system & 42.4 & & 100.7 \\
\hline
\end{tabular}

Source: Botswana authorities.

1/ Data refers to end-2003.

2/ Refers to funds invested domestically which are 43 percent of total pension funds. 
Table 29. Botswana: Balance of Payments, 2000-2005 1/

(In millions of U.S. dollars, unless otherwise indicated)

\begin{tabular}{|c|c|c|c|c|c|c|}
\hline & 2000 & 2001 & 2002 & 2003 & $\begin{array}{l}2004 \\
\text { Rev. }\end{array}$ & $\begin{array}{l}2005 \\
\text { Prel. }\end{array}$ \\
\hline Current account balance & 547 & 600 & 197 & 464 & 291 & 1,565 \\
\hline Trade balance & 904 & 713 & 710 & 900 & 840 & 1,769 \\
\hline \multicolumn{7}{|l|}{ Of which } \\
\hline Diamonds & 2,240 & 1,936 & 1,978 & 2,374 & 2,827 & 3,284 \\
\hline $\begin{array}{c}\text { Imports, f.o.b } \\
\text { Of which }\end{array}$ & \multicolumn{5}{|c|}{ Of which } & $-2,791$ \\
\hline Food, beverages, and tobacco & -294 & -254 & -329 & -412 & -474 & -440 \\
\hline Chemical and rubber products & -203 & -187 & -217 & -290 & -386 & -381 \\
\hline Fuel & -103 & -122 & -122 & -167 & -384 & -426 \\
\hline Metal and metal products & -151 & -140 & -161 & -187 & -271 & -243 \\
\hline Machinery and electrical equipment & -463 & -357 & -375 & -448 & -567 & -523 \\
\hline Services & -223 & -174 & -29 & -9 & -44 & -8 \\
\hline Transportation & -174 & -155 & -167 & -180 & -210 & -236 \\
\hline Travel & 25 & 26 & 136 & 228 & 276 & 276 \\
\hline Other services & -73 & -45 & 3 & -57 & -110 & -49 \\
\hline Income & -352 & -138 & -700 & -718 & $-1,037$ & -724 \\
\hline Compensation of employees & -37 & -37 & -39 & -55 & -60 & -60 \\
\hline Investment income & -315 & -101 & -662 & -663 & -977 & -664 \\
\hline \multicolumn{7}{|l|}{ Of which } \\
\hline Earnings on reserves & 282 & 285 & 265 & 246 & 240 & 255 \\
\hline Current transfers & 218 & 198 & 217 & 291 & 532 & 529 \\
\hline Capital and financial account & -164 & -506 & -202 & -358 & -303 & -139 \\
\hline Capital account & 38 & 6 & 16 & 23 & 32 & 31 \\
\hline Financial account & -202 & -512 & -218 & -380 & -335 & -170 \\
\hline Direct investment & 55 & -351 & 362 & 213 & 434 & 285 \\
\hline Portfolio investment & -43 & -63 & -414 & -522 & -472 & -369 \\
\hline Other investment & -214 & -99 & -165 & -70 & -297 & -86 \\
\hline \multicolumn{7}{|l|}{ Of which } \\
\hline Net government long-term borrowing & -32 & -17 & -23 & -22 & -25 & -10 \\
\hline Other net private long-term borrowing & 2 & 2 & 2 & 3 & 4 & 5 \\
\hline Short-term borrowing & 46 & 76 & 71 & 93 & 63 & 59 \\
\hline Net errors and omissions $2 /$ & -293 & -516 & -419 & -241 & 338 & -816 \\
\hline Reserve assets (increase -) 2/ & -89 & 421 & 424 & 135 & -327 & -610 \\
\hline \multicolumn{7}{|l|}{ Memorandum items: } \\
\hline Current account balance (in percent of GDP) & 8.8 & 9.9 & 3.3 & 5.6 & 3.0 & 15.4 \\
\hline Trade balance (in percent of GDP) & 14.6 & 11.8 & 11.9 & 10.8 & 8.5 & 17.3 \\
\hline End-of-year gross official reserves & 6,319 & 5,897 & 5,474 & 5,339 & 5,665 & 6,276 \\
\hline (in months of imports of goods and services) & 32.6 & 33.0 & 30.3 & 23.0 & 18.4 & 20.8 \\
\hline \multicolumn{7}{|l|}{ Exchange rates } \\
\hline U.S. dollars per pula (period average) & 0.20 & 0.17 & 0.16 & 0.20 & 0.22 & 0.19 \\
\hline U.S. dollars per pula (end of period) & 0.19 & 0.14 & 0.18 & 0.23 & 0.23 & 0.18 \\
\hline
\end{tabular}

Sources: Botswana authorities; and IMF staff estimates.

1/ Based on pula-denominated estimates converted at period-average exchange rate.

$2 /$ Includes valuation adjustment. 
Table 30. Botswana: Value of Principal Exports and Imports, 2000-2005

\begin{tabular}{|c|c|c|c|c|c|c|}
\hline & 2000 & 2001 & 2002 & 2003 & $\begin{array}{c}2004 \\
\text { Rev. }\end{array}$ & $\begin{array}{l}2005 \\
\text { Prel. }\end{array}$ \\
\hline & \multicolumn{6}{|c|}{ (In millions of U.S. dollars) } \\
\hline Diamonds & 2,240 & 1,936 & 1,978 & 2,374 & 2,827 & 3,284 \\
\hline Nondiamond & 442 & 389 & 376 & 662 & 907 & 1276 \\
\hline Meat & 55 & 73 & 44 & 53 & 61 & 60 \\
\hline Copper nickel & 108 & 70 & 76 & 141 & 163 & 445 \\
\hline Textiles & 48 & 33 & 29 & 46 & 121 & 216 \\
\hline Soda ash & 41 & 36 & 42 & 47 & 54 & 64 \\
\hline Other & 191 & 176 & 183 & 375 & 508 & 491 \\
\hline Total exports, f.o.b. & 2,682 & 2,325 & 2,353 & 3,035 & 3,734 & 4,559 \\
\hline Food, beverages, and tobacco & 294 & 254 & 329 & 412 & 474 & 440 \\
\hline Wood and paper products & 161 & 160 & 146 & 213 & 315 & 263 \\
\hline Textile and footwear & 121 & 85 & 93 & 118 & 158 & 150 \\
\hline Chemical and rubber products & 203 & 187 & 217 & 290 & 386 & 381 \\
\hline Fuel & 103 & 122 & 122 & 167 & 384 & 426 \\
\hline Metal and metal products & 151 & 140 & 161 & 187 & 271 & 243 \\
\hline Machinery and electrical equipment & 463 & 357 & 375 & 448 & 567 & 523 \\
\hline Vehicle and transport equipment & 258 & 221 & 321 & 299 & 467 & 400 \\
\hline Other goods & 332 & 289 & 272 & 324 & 378 & 383 \\
\hline \multirow[t]{2}{*}{ Total imports, c.i.f. } & 2,085 & 1,815 & 2,035 & 2,457 & 3,398 & 3,208 \\
\hline & \multicolumn{6}{|c|}{ (In percent of total) } \\
\hline Diamonds & 83.5 & 83.3 & 84.0 & 78.2 & 75.7 & 72.0 \\
\hline Nondiamond & 16.5 & 16.7 & 16.0 & 21.8 & 24.3 & 28.0 \\
\hline Meat & 2.0 & 3.2 & 1.9 & 1.7 & 1.6 & 1.3 \\
\hline Copper nickel & 4.0 & 3.0 & 3.3 & 4.6 & 4.4 & 9.8 \\
\hline Textiles & 1.8 & 1.4 & 1.2 & 1.5 & 3.2 & 4.7 \\
\hline Soda ash & 1.5 & 1.5 & 1.8 & 1.5 & 1.4 & 1.4 \\
\hline Other & 7.1 & 7.6 & 7.8 & 12.4 & 13.6 & 10.8 \\
\hline Total exports, f.o.b. & 100.0 & 100.0 & 100.0 & 100.0 & 100.0 & 100.0 \\
\hline Food, beverages, and tobacco & 14.1 & 14.0 & 16.2 & 16.8 & 13.9 & 13.7 \\
\hline Wood and paper products & 7.7 & 8.8 & 7.2 & 8.7 & 9.3 & 8.2 \\
\hline Textile and footwear & 5.8 & 4.7 & 4.6 & 4.8 & 4.6 & 4.7 \\
\hline Chemical and rubber products & 9.7 & 10.3 & 10.6 & 11.8 & 11.4 & 11.9 \\
\hline Fuel & 4.9 & 6.7 & 6.0 & 6.8 & 11.3 & 13.3 \\
\hline Metal and metal products & 7.2 & 7.7 & 7.9 & 7.6 & 8.0 & 7.6 \\
\hline Machinery and electrical equipment & 22.2 & 19.7 & 18.4 & 18.2 & 16.7 & 16.3 \\
\hline Vehicle and transport equipment & 12.4 & 12.2 & 15.8 & 12.2 & 13.7 & 12.5 \\
\hline Other goods & 15.9 & 15.9 & 13.4 & 13.2 & 11.1 & 11.9 \\
\hline Total imports, c.i.f. & 100.0 & 100.0 & 100.0 & 100.0 & 100.0 & 100.0 \\
\hline
\end{tabular}

Source: Botswana authorities; and IMF staff estimates. 
Table 31. Botswana: External Trade Indices, 2000/01-2004/05 1/

\begin{tabular}{|c|c|c|c|c|c|}
\hline & $2000 / 01$ & $2001 / 02$ & $2002 / 03$ & $2003 / 04$ & $2004 / 05$ \\
\hline \multicolumn{6}{|l|}{ Values (in millions of pula) } \\
\hline Exports of goods & 15,983 & 13,844 & 15,797 & 14,182 & 19,557 \\
\hline Exports of services & 1,843 & 2,555 & 3,385 & 3,694 & 4,709 \\
\hline Total exports (goods and services) & 17,826 & 16,399 & 19,182 & 17,875 & 24,266 \\
\hline Imports of goods & $-8,965$ & $-10,038$ & $-12,780$ & $-12,112$ & $-14,225$ \\
\hline Imports of services & $-1,841$ & $-2,006$ & $-2,129$ & $-2,512$ & $-2,879$ \\
\hline Total imports (goods and services) & $-10,806$ & $-12,044$ & $-14,909$ & $-14,624$ & $-17,105$ \\
\hline \multicolumn{6}{|c|}{ Volume (1993/94 prices, millions of pula) } \\
\hline Exports of goods & 7,918 & 6,494 & 6,747 & 5,674 & 7,295 \\
\hline Exports of services & 1,049 & 1,378 & 1,661 & 1,697 & 2,021 \\
\hline Total exports (goods and services) & 8,967 & 7,871 & 8,408 & 7,371 & 9,316 \\
\hline Imports of goods & $-5,048$ & $-5,345$ & $-6,224$ & $-5,505$ & $-6,035$ \\
\hline Imports of services & $-1,039$ & $-1,092$ & $-1,049$ & $-1,156$ & $-1,210$ \\
\hline Total imports (goods and services) & $-6,087$ & $-6,437$ & $-7,273$ & $-6,661$ & $-7,246$ \\
\hline \multicolumn{6}{|l|}{ Price indices $(1993 / 94=100)$} \\
\hline Exports of goods & 201.9 & 213.2 & 234.1 & 249.9 & 269.2 \\
\hline Exports of services & 175.7 & 185.4 & 203.8 & 217.6 & 234.4 \\
\hline Total exports (goods and services) & 198.8 & 208.3 & 228.1 & 242.5 & 260.7 \\
\hline Imports of goods & 177.6 & 187.8 & 205.3 & 220.0 & 237.1 \\
\hline Imports of services & 177.2 & 183.7 & 202.9 & 217.3 & 236.9 \\
\hline Total imports (goods and services) & 177.5 & 187.1 & 205.0 & 219.5 & 236.9 \\
\hline
\end{tabular}

Source: National accounts data.

1/ Year beginning July 1. 
Table 32. Botswana: Direction of Trade, 2000-2005

\begin{tabular}{|c|c|c|c|c|c|c|}
\hline & 2000 & 2001 & 2002 & 2003 & 2004 & 2005 \\
\hline & \multicolumn{6}{|c|}{ (In millions of pula) } \\
\hline Exports, f.o.b. & 14,260 & 14,659 & 16,109 & 13,908 & 16,490 & 22,459 \\
\hline Southern African Customs Union (SACU) & 984 & 948 & 1,249 & 1,221 & 1,587 & 2,032 \\
\hline Zimbabwe & 556 & 382 & 398 & 407 & 614 & 914 \\
\hline Other Africa & 131 & 111 & 88 & 45 & 40 & 105 \\
\hline United Kingdom & 9,913 & 12,584 & 12,835 & 10,791 & 12,267 & 17,011 \\
\hline Other Europe & 2,488 & 463 & 382 & 244 & 302 & 288 \\
\hline United States & 86 & 37 & 107 & 61 & 264 & 498 \\
\hline All other & 102 & 134 & 1,050 & 1,139 & 1,416 & 1,610 \\
\hline Imports, c.i.f. & 10,230 & 10,564 & 15,309 & 12,118 & 15,787 & 16,592 \\
\hline SACU & 7,867 & 8,201 & 12,454 & 10,492 & 13,171 & 14,125 \\
\hline Zimbabwe & 369 & 335 & 218 & 177 & 241 & 246 \\
\hline Other Africa & 35 & 35 & 148 & 48 & 43 & 187 \\
\hline United Kingdom & 442 & 468 & 477 & 303 & 483 & 222 \\
\hline Other Europe & 900 & 833 & 1,124 & 627 & 890 & 863 \\
\hline Korea, Republic of & 22 & 22 & 12 & 27 & 21 & 29 \\
\hline United States & 174 & 190 & 191 & 84 & 201 & 202 \\
\hline \multirow[t]{2}{*}{ All other } & 421 & 480 & 686 & 376 & 736 & 717 \\
\hline & \multicolumn{6}{|c|}{ (In percent of total) } \\
\hline Exports, f.o.b. & 100.0 & 100.0 & 100.0 & 100.0 & 100.0 & 100.0 \\
\hline SACU & 6.9 & 6.5 & 7.8 & 8.8 & 9.6 & 9.0 \\
\hline Zimbabwe & 3.9 & 2.6 & 2.5 & 2.9 & 3.7 & 4.1 \\
\hline Other Africa & 0.9 & 0.8 & 0.5 & 0.3 & 0.2 & 0.5 \\
\hline United Kingdom & 69.5 & 85.8 & 79.7 & 77.6 & 74.4 & 75.7 \\
\hline Other Europe & 17.4 & 3.2 & 2.4 & 1.8 & 1.8 & 1.3 \\
\hline United States & 0.6 & 0.3 & 0.7 & 0.4 & 1.6 & 2.2 \\
\hline All other & 0.7 & 0.9 & 6.5 & 8.2 & 8.6 & 7.2 \\
\hline Imports, c.i.f. & 100.0 & 100.0 & 100.0 & 100.0 & 100.0 & 100.0 \\
\hline SACU & 76.9 & 77.6 & 81.4 & 86.6 & 83.4 & 85.1 \\
\hline Zimbabwe & 3.6 & 3.2 & 1.4 & 1.5 & 1.5 & 1.5 \\
\hline Other Africa & 0.3 & 0.3 & 1.0 & 0.4 & 0.3 & 1.1 \\
\hline United Kingdom & 4.3 & 4.4 & 3.1 & 2.5 & 3.1 & 1.3 \\
\hline Other Europe & 8.8 & 7.9 & 7.3 & 5.2 & 5.6 & 5.2 \\
\hline Korea, Republic of & 0.2 & 0.2 & 0.1 & 0.2 & 0.1 & 0.2 \\
\hline United States & 1.7 & 1.8 & 1.2 & 0.7 & 1.3 & 1.2 \\
\hline All other & 4.1 & 4.5 & 4.5 & 3.1 & 4.7 & 4.3 \\
\hline
\end{tabular}

Source: Customs and Excise Department. 
Table 33. Botswana: Public Sector External Debt, 2001-2006 1/

\begin{tabular}{|c|c|c|c|c|c|c|}
\hline & 2001 & 2002 & 2003 & 2004 & 2005 & $\begin{array}{l}2006 \\
\text { Rev. }\end{array}$ \\
\hline & \multicolumn{6}{|c|}{ (In millions of U.S. dollars; end of period) } \\
\hline Total external public debt $2 /$ & 347.4 & 533.6 & 494.0 & 464.7 & 397.1 & 389.2 \\
\hline Bilateral loans & 112.2 & 166.0 & 138.1 & 132.9 & 108.9 & 106.9 \\
\hline United States & 15.5 & 26.2 & 19.4 & 16.5 & 15.4 & 15.2 \\
\hline United Kingdom & 0.0 & 0.0 & 0.0 & 0.0 & 0.0 & 0.0 \\
\hline China & 20.8 & 34.7 & 31.2 & 30.2 & 24.6 & 24.1 \\
\hline Belgium & 0.7 & 1.0 & 1.1 & 1.0 & 0.9 & 0.9 \\
\hline Kuwait & 7.5 & 15.7 & 13.0 & 11.2 & 10.1 & 9.8 \\
\hline Germany & 0.0 & 0.0 & 0.0 & 0.0 & 0.0 & 0.0 \\
\hline Nigeria & 0.0 & 0.0 & 0.0 & 0.0 & 0.0 & 0.0 \\
\hline Japan & 66.7 & 87.9 & 73.3 & 74.0 & 57.9 & 56.9 \\
\hline Saudi Arabia & 0.9 & 0.5 & 0.0 & 0.0 & 0.0 & 0.0 \\
\hline Multilateral loans & 220.9 & 347.6 & 343.5 & 321.8 & 278.6 & 273.1 \\
\hline African Development Bank/Fund 3/ & 124.6 & 175.5 & 190.7 & 182.3 & 153.4 & 153.1 \\
\hline Arab Bank for Economic Development in Africa & 13.7 & 28.3 & 23.2 & 18.9 & 18.2 & 17.8 \\
\hline European Economic Community & 0.0 & 0.0 & 0.0 & 0.0 & 0.0 & 0.0 \\
\hline European Investment Bank & 48.9 & 84.8 & 87.1 & 84.7 & 74.3 & 71.1 \\
\hline International Bank for Reconstruction and Development & 13.5 & 15.6 & 6.7 & 4.2 & 4.9 & 4.4 \\
\hline International Development Association & 6.6 & 14.2 & 9.4 & 8.2 & 7.2 & 6.9 \\
\hline International Fund for Agriculture Development & 0.0 & 0.0 & 0.0 & 0.0 & 0.0 & 0.0 \\
\hline Nordic Development Fund & 0.0 & 0.0 & 0.0 & 0.0 & 0.0 & 0.0 \\
\hline Nordic Investment Bank & 10.2 & 24.5 & 23.5 & 21.3 & 18.4 & 18.0 \\
\hline Organization of Petroleum Exporting Countries & 3.4 & 4.7 & 3.0 & 2.1 & 2.2 & 1.8 \\
\hline UN Capital Development Fund & 0.0 & 0.0 & 0.0 & 0.0 & 0.0 & 0.0 \\
\hline Commercial banks & 0.0 & 0.0 & 0.0 & 0.0 & 0.0 & 0.0 \\
\hline Export credits & 14.3 & 20.0 & 12.5 & 10.0 & 9.6 & 9.2 \\
\hline \multicolumn{7}{|l|}{ Memorandum items: } \\
\hline & \multicolumn{6}{|c|}{ (In percent) } \\
\hline $\begin{array}{l}\text { Total external public debt } \\
\text { (in percent of GDP) }\end{array}$ & 8.0 & 8.5 & 5.7 & 4.5 & 4.0 & 3.7 \\
\hline (in percent of exports of goods and services) & 15.6 & 16.3 & 12.3 & 9.8 & 7.6 & 7.2 \\
\hline
\end{tabular}

Sources: Ministry of Finance and Development Planning; and IMF staff estimates.

1/ End of March.

2/ Disbursed government and government-guaranteed outstanding debt, with original maturity of one year and more.

3/ African Development Bank/Fund for 2000. 
Table 34. Botswana: External Debt-Service Payments and Disbursements, 2000-2005 1/

\begin{tabular}{|c|c|c|c|c|c|c|}
\hline & 2000 & 2001 & 2002 & 2003 & 2004 & $\begin{array}{c}2005 \\
\text { Est. }\end{array}$ \\
\hline & \multicolumn{6}{|c|}{ (In millions of U.S. dollars) } \\
\hline \multicolumn{7}{|l|}{ Central government } \\
\hline Disbursed outstanding debt & 498.1 & 451.2 & 431.6 & 425.3 & 427.9 & 397.7 \\
\hline Disbursements & 22.2 & 7.3 & 12.9 & 5.1 & 13.2 & 5.1 \\
\hline Principal repayments & 33.3 & 41.5 & 48.5 & 49.7 & 37.5 & 32.5 \\
\hline Interest payments & 31.8 & 17.9 & 20.2 & 17.4 & 41.5 & 23.9 \\
\hline Other charges & 0.0 & 0.0 & 0.0 & 0.0 & 0.0 & 1.0 \\
\hline Total debt service & 65.1 & 59.4 & 68.7 & 67.1 & 78.9 & 56.4 \\
\hline \multicolumn{7}{|l|}{ Public corporations } \\
\hline Disbursed outstanding debt & 23.9 & 19.6 & 15.3 & 17.2 & 13.5 & 12.5 \\
\hline Disbursements & 1.0 & 0.8 & 0.0 & 0.0 & 0.0 & 0.0 \\
\hline Principal repayments & 5.0 & 4.9 & 5.5 & 4.8 & 4.3 & 3.7 \\
\hline Interest payments & 2.9 & 2.4 & 2.8 & 2.4 & 1.9 & 1.1 \\
\hline Other charges & 0.0 & 0.0 & 0.0 & 0.0 & 0.0 & 1.0 \\
\hline Total debt service & 7.8 & 7.3 & 8.3 & 7.2 & 6.2 & 4.8 \\
\hline \multicolumn{7}{|l|}{ Public and publicly guaranteed } \\
\hline Disbursed outstanding debt & 522.1 & 570.8 & 447.0 & 442.6 & 441.3 & 410.1 \\
\hline Disbursements & 23.1 & 8.1 & 12.9 & 5.1 & 13.2 & 5.1 \\
\hline Principal repayments & 38.2 & 46.4 & 54.0 & 54.5 & 41.8 & 36.3 \\
\hline Interest payments & 34.7 & 20.2 & 23.0 & 19.8 & 43.4 & 25.0 \\
\hline Other charges & 0.0 & 0.0 & 0.0 & 0.0 & 0.0 & 1.0 \\
\hline Total debt service & 73.0 & 66.6 & 77.0 & 74.3 & 85.1 & 61.3 \\
\hline \multicolumn{7}{|l|}{ Memorandum items: } \\
\hline & \multicolumn{6}{|c|}{ (In percent of exports of goods and services) } \\
\hline Debt-service ratios & 2.4 & 2.5 & 2.7 & 2.0 & 1.9 & 1.1 \\
\hline Central government & 2.2 & 2.2 & 2.4 & 1.8 & 1.8 & 1.0 \\
\hline Public corporations & 0.3 & 0.3 & 0.3 & 0.2 & 0.1 & 0.1 \\
\hline
\end{tabular}

Sources: Ministry of Finance and Development Planning; and IMF staff estimates.

1/ End of March. 
Table 35. Botswana: Outstanding of Government Bonds, 2004-2006 1/ (In millions of pula)

\begin{tabular}{|c|c|c|c|c|c|}
\hline & \multirow{2}{*}{$\begin{array}{r}\text { Maturity } \\
\text { (year) }\end{array}$} & \multirow{2}{*}{$\begin{array}{r}\text { Date } \\
\text { of maturity }\end{array}$} & \multicolumn{3}{|c|}{ Outstanding at end-March } \\
\hline & & & 2004 & 2005 & 2006 \\
\hline BW001 & 2 & Jun 1, 2005 & 750 & 750 & \\
\hline BW002 & 5 & Mar 1, 2008 & 850 & 850 & 850 \\
\hline BW003 & 12 & Oct 31,2015 & 900 & 900 & 900 \\
\hline Total & & & 2,500 & 2,500 & 1,750 \\
\hline
\end{tabular}

Source: Ministry of Finance and Development Planning.

1/ Three government bonds with maturities of 2, 5, and 12 years were auctioned for the period March to November 2003. 
Table 36. Botswana: Average Terms of New Public Sector External Borrowing, 1999-2005

\begin{tabular}{|c|c|c|c|c|c|c|c|}
\hline & 1999 & 2000 & 2001 & 2002 & 2003 & 2004 & 2005 \\
\hline Interest rate (in percent a year) & 2.3 & 2.3 & $\ldots$ & $\ldots$ & $\ldots$ & $\ldots$ & ... \\
\hline Maturity (in years) & 14.5 & 14.5 & $\ldots$ & $\ldots$ & $\ldots$ & $\ldots$ & $\ldots$ \\
\hline Grace period (in years) & 4.7 & 4.7 & $\cdots$ & ... & $\ldots$ & $\ldots$ & ... \\
\hline Grant element (in percent) & 40.7 & 40.7 & $\ldots$ & $\ldots$ & $\ldots$ & $\ldots$ & $\ldots$ \\
\hline
\end{tabular}


Table 37. Botswana: Developments in the Exchange Rate, 1990-2006 (Index, 2000 $=100$, unless otherwise indicated; period average)

\begin{tabular}{|c|c|c|c|c|c|}
\hline & \multicolumn{2}{|c|}{ Effective Exchange Rate } & \multicolumn{3}{|c|}{ Bilateral Exchange Rates 1/ } \\
\hline & Real & Nominal & $\begin{array}{r}\text { South African } \\
\text { rand } \\
\end{array}$ & U.S. dollar & SDR \\
\hline 1990 & 86.7 & 106.5 & 1.37 & 0.53 & 0.38 \\
\hline 1991 & 91.3 & 109.9 & 1.32 & 0.48 & 0.34 \\
\hline 1992 & 96.7 & 114.0 & 1.36 & 0.44 & 0.32 \\
\hline 1993 & 102.8 & 117.1 & 1.33 & 0.39 & 0.28 \\
\hline 1994 & 101.7 & 113.5 & 1.30 & 0.37 & 0.25 \\
\hline 1995 & 98.2 & 108.4 & 1.29 & 0.35 & 0.24 \\
\hline 1996 & 95.4 & 103.7 & 1.29 & 0.30 & 0.21 \\
\hline 1997 & 93.6 & 100.1 & 1.26 & 0.27 & 0.20 \\
\hline 1998 & 93.5 & 99.2 & 1.31 & 0.24 & 0.18 \\
\hline 1999 & 95.5 & 98.6 & 1.32 & 0.22 & 0.16 \\
\hline 2000 & 100.0 & 100.0 & 1.36 & 0.20 & 0.15 \\
\hline 2001 & 103.8 & 102.7 & 1.47 & 0.17 & 0.14 \\
\hline 2002 & 109.3 & 108.5 & 1.66 & 0.16 & 0.12 \\
\hline 2003 & 115.0 & 112.4 & 1.53 & 0.20 & 0.15 \\
\hline 2004 Jan & 115.6 & 112.1 & 1.51 & 0.22 & 0.15 \\
\hline Feb & 108.7 & 105.1 & 1.41 & 0.21 & 0.14 \\
\hline Mar & 113.0 & 108.5 & 1.37 & 0.21 & 0.14 \\
\hline Apr & 106.5 & 101.7 & 1.37 & 0.21 & 0.14 \\
\hline May & 114.7 & 109.0 & 1.38 & 0.20 & 0.14 \\
\hline Jun & 109.7 & 104.5 & 1.36 & 0.21 & 0.15 \\
\hline Jul & 108.5 & 103.4 & 1.34 & 0.22 & 0.15 \\
\hline Aug & 110.4 & 105.2 & 1.36 & 0.21 & 0.15 \\
\hline Sep & 110.0 & 104.1 & 1.37 & 0.21 & 0.14 \\
\hline Oct & 107.8 & 101.9 & 1.36 & 0.21 & 0.15 \\
\hline Nov & 107.9 & 102.1 & 1.34 & 0.22 & 0.15 \\
\hline Dec & 109.7 & 103.3 & 1.33 & 0.23 & 0.15 \\
\hline 2005 Jan & 112.0 & 104.9 & 1.34 & 0.22 & 0.15 \\
\hline Feb & 109.2 & 102.4 & 1.34 & 0.22 & 0.15 \\
\hline Mar & 114.8 & 107.8 & 1.34 & 0.22 & 0.15 \\
\hline Apr & 111.9 & 105.1 & 1.35 & 0.22 & 0.15 \\
\hline May & 112.3 & 104.9 & 1.34 & 0.21 & 0.14 \\
\hline Jun & 101.4 & 94.1 & 1.22 & 0.18 & 0.12 \\
\hline Jul & 102.5 & 95.0 & 1.21 & 0.18 & 0.12 \\
\hline Aug & 103.1 & 94.7 & 1.19 & 0.18 & 0.13 \\
\hline Sep & 102.9 & 94.3 & 1.18 & 0.19 & 0.13 \\
\hline Oct & 105.6 & 95.5 & 1.18 & 0.18 & 0.12 \\
\hline Nov & 105.4 & 95.2 & 1.18 & 0.18 & 0.12 \\
\hline Dec & 104.9 & 94.5 & 1.15 & 0.18 & 0.13 \\
\hline 2006 Jan & 110.4 & 94.9 & 1.14 & 0.19 & 0.13 \\
\hline Feb & 109.6 & 94.3 & 1.13 & 0.19 & 0.13 \\
\hline Mar & 109.7 & 93.8 & 1.13 & 0.18 & 0.13 \\
\hline Apr & 109.3 & 93.2 & 1.12 & 0.18 & 0.13 \\
\hline May & $\ldots$ & $\ldots$ & 1.14 & 0.18 & 0.12 \\
\hline
\end{tabular}

Sources: IMF Effective Exchange Rate Facility Database; and Botswana authorities.

1/ Foreign currency per Botswana pula. Increase in value indicates an appreciation of the pula, 1990-2004. 


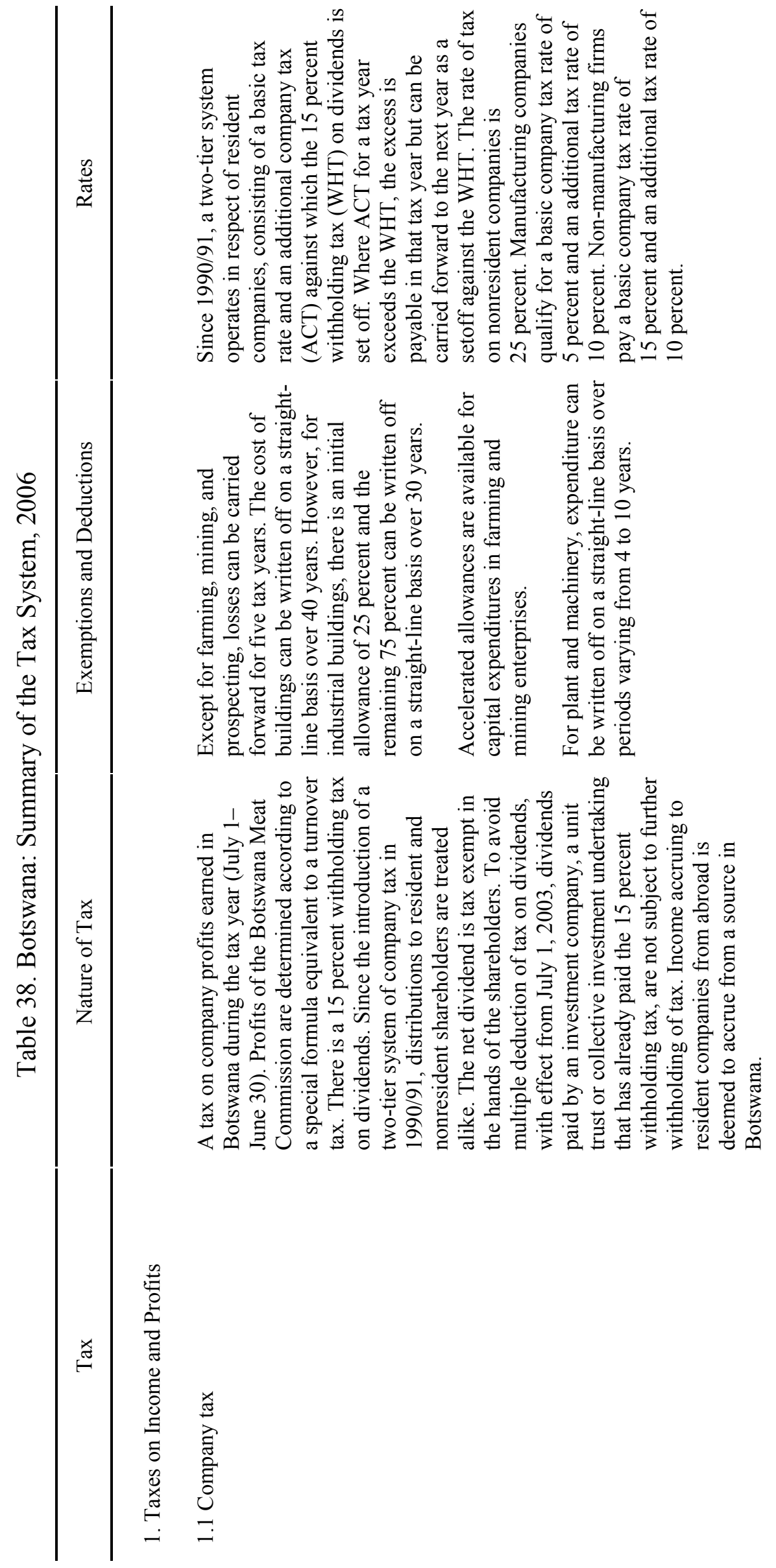




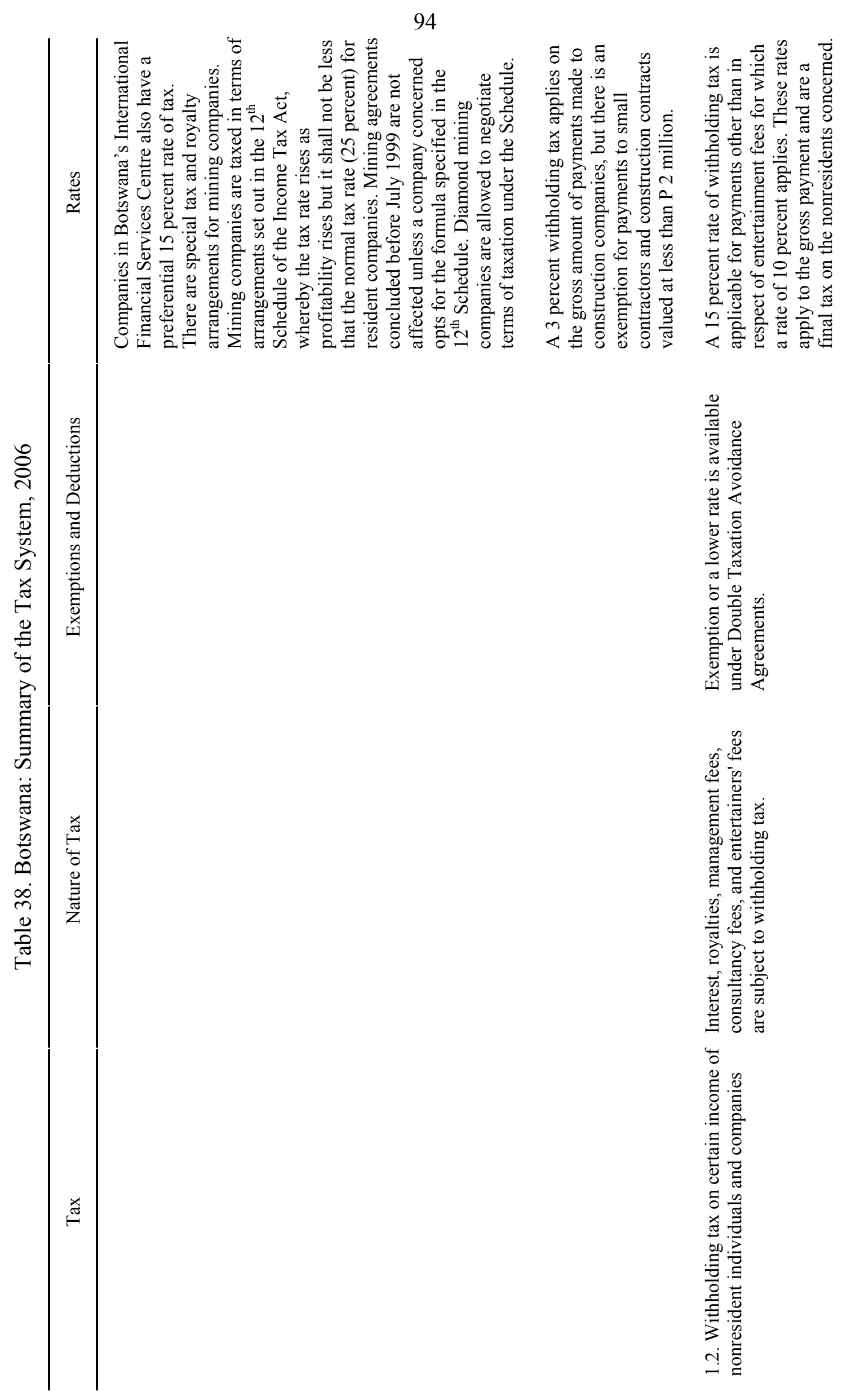




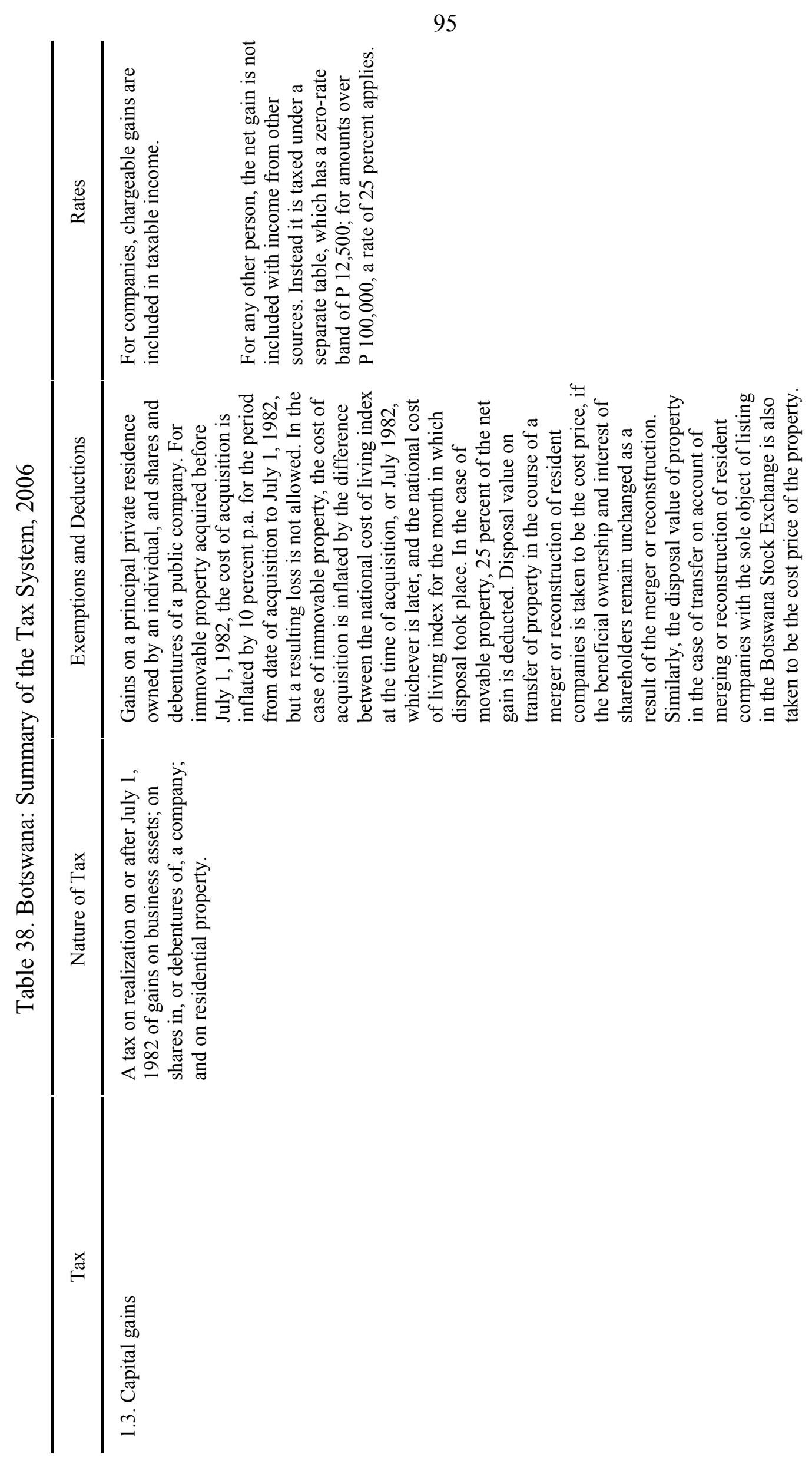




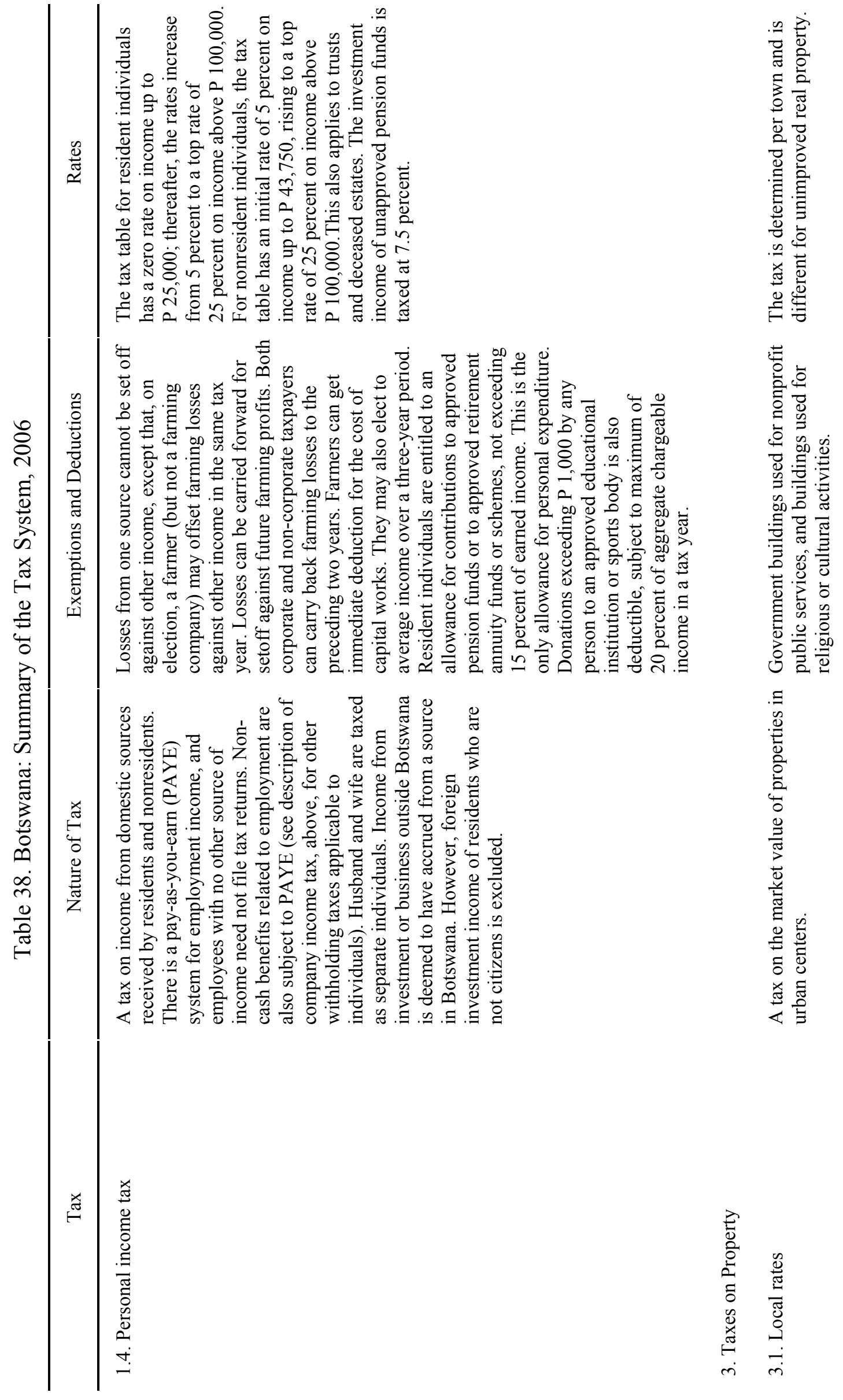




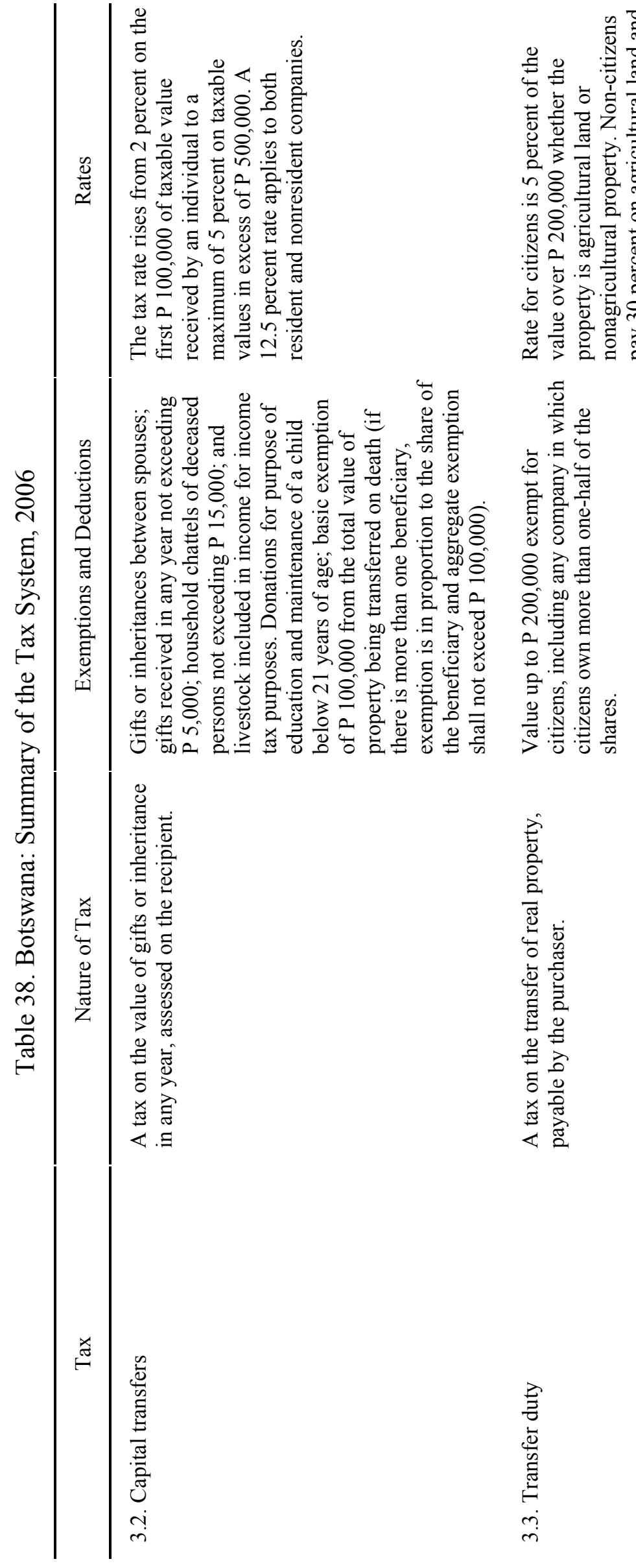




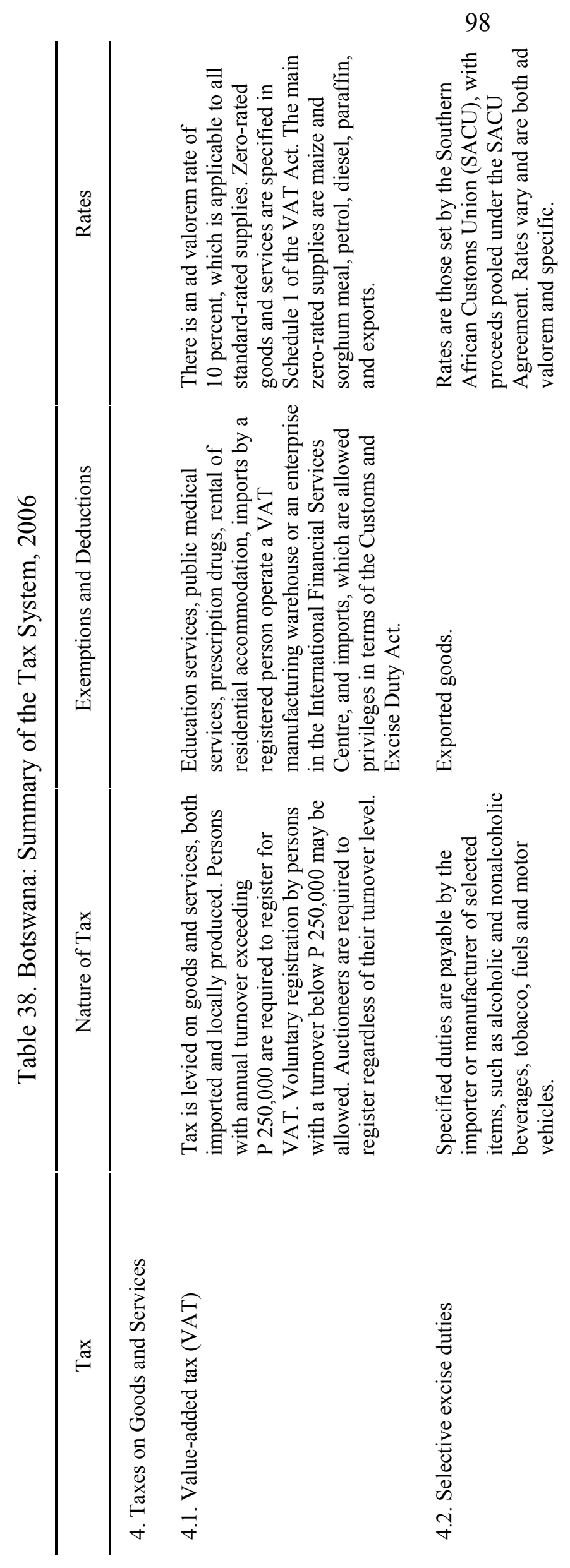




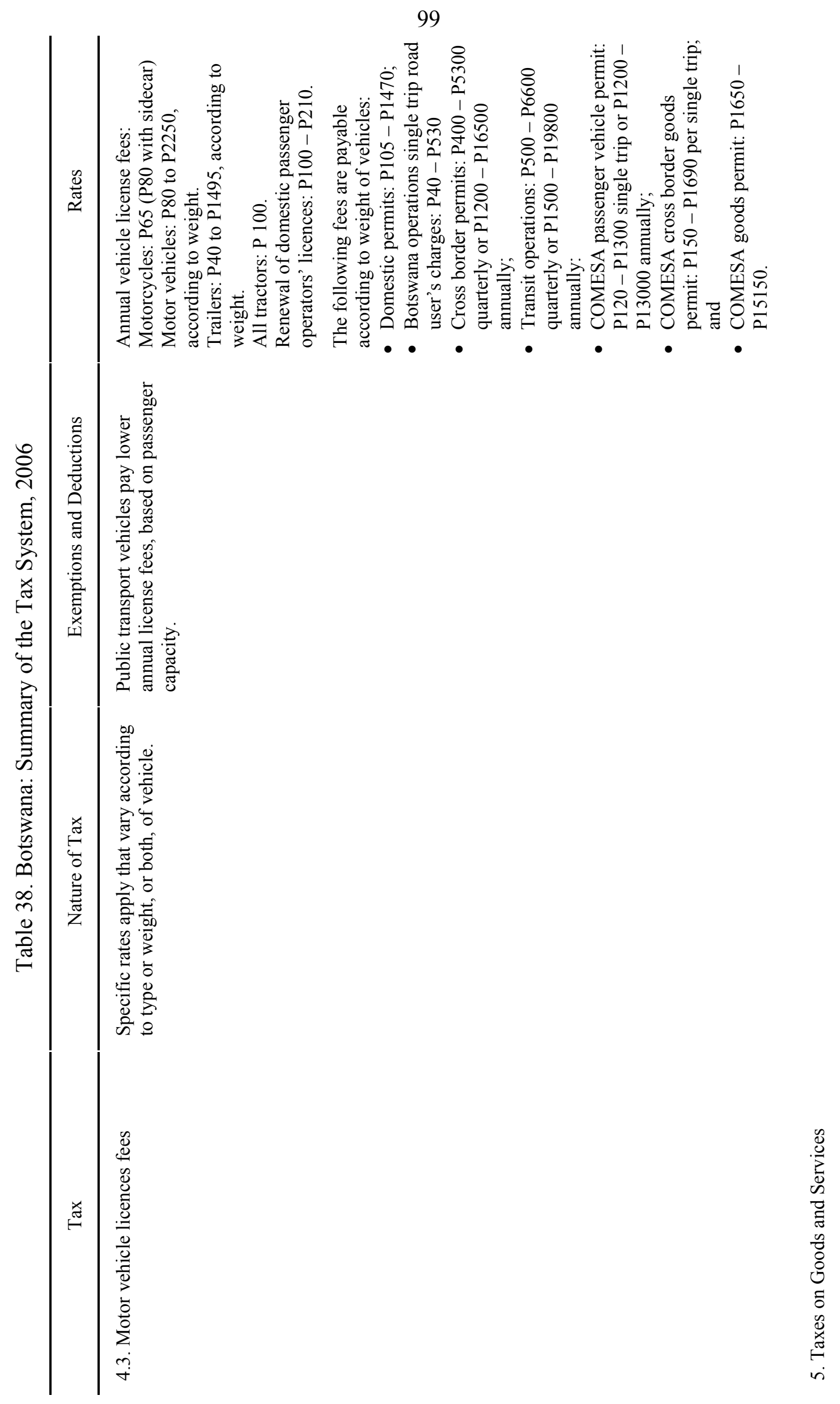




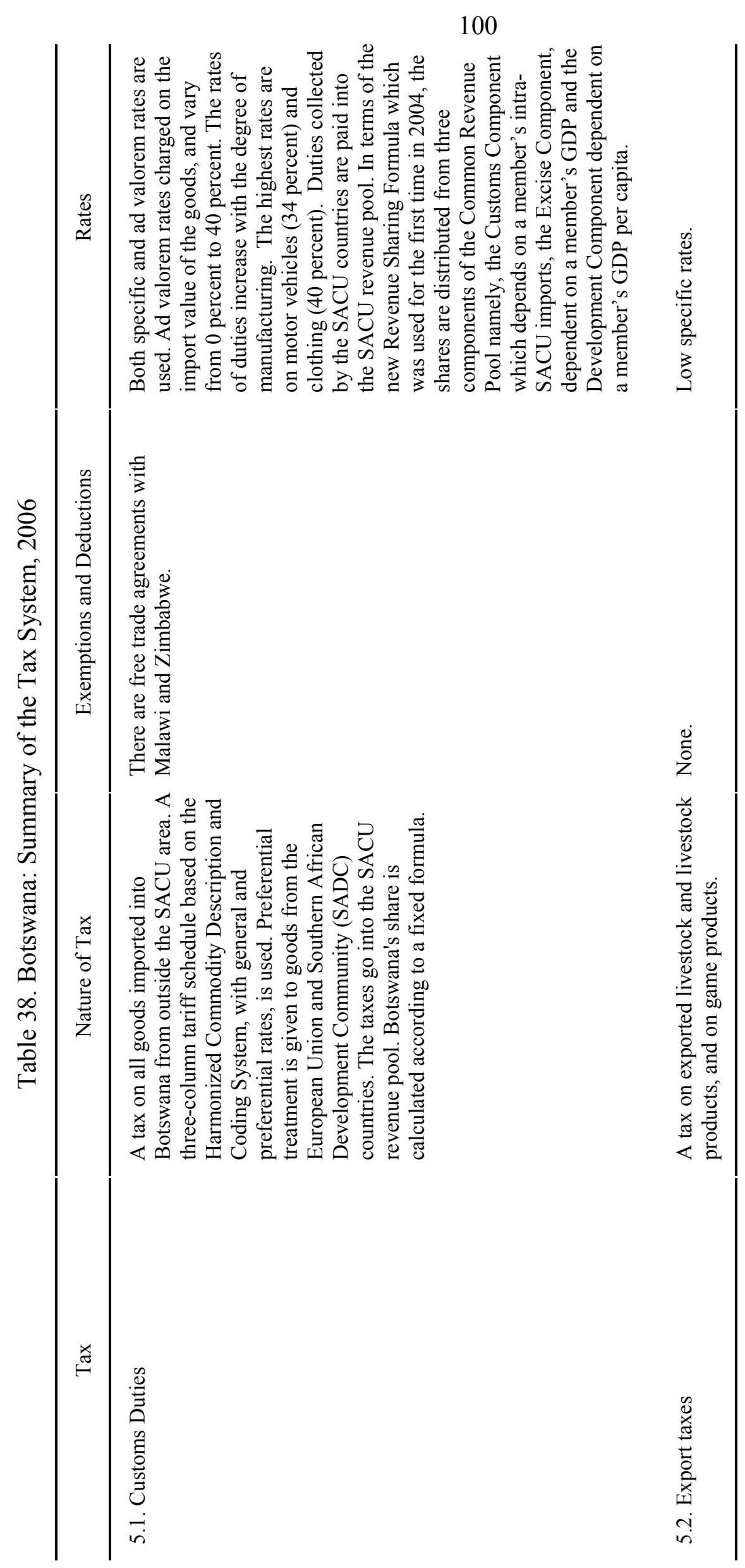

